UNIVERSIDADE DE SÃO PAULO

INSTITUTO DE PSICOLOGIA

JOSÉ EDUARDO ASSUNÇÃO AZEVEDO

\title{
Psicanálise e Justiça Criminal: \\ questões e posicionamentos sobre uma clínica da violência doméstica
}

São Paulo

Março de 2008 


\section{JOSÉ EDUARDO ASSUNÇÃO AZEVEDO}

\section{Psicanálise e Justiça Criminal:}

questões e posicionamentos sobre uma clínica da violência doméstica

Dissertação apresentada ao Departamento de Psicologia Clínica do Instituto de Psicologia da Universidade de São Paulo para obtenção do título de Mestre em Psicologia.

Área de concentração: Psicologia Clínica

Orientadora: Prof. ${ }^{\text {a }}$ Dr. ${ }^{\text {a }}$ Maria Lúcia de Araújo Andrade

São Paulo

Março de 2008 
III

AUTORIZO A REPRODUÇÃO E DIVULGAÇÃO TOTAL E PARCIAL DESTE TRABALHO, POR QUALQUER MEIO CONVENCIONAL OU ELETRÔNICO, PARA FINS DE ESTUDO E PESQUISA, DESDE QUE CITADA A FONTE.

Azevedo, José Eduardo Assunção.

Psicanálise e Justiça Criminal: questões e posicionamentos sobre uma clínica da violência doméstica / José Eduardo Assunção Azevedo; orientadora: Dra. Maria Lúcia de Araújo Andrade.

- São Paulo, 2008.

Dissertação (Mestrado) - Programa de Pós-graduação em Psicologia - Área de concentração: Psicologia Clínica - Instituto de Psicologia da Universidade de São Paulo.

1. psicanálise. 2. direito penal. 3. violência doméstica. 
FOLHA DE APROVAÇÃO

José Eduardo Assunção Azevedo

Psicanálise e Justiça Criminal: questões e posicionamentos sobre uma cínica da violência doméstica

Dissertação apresentada ao Departamento de Psicologia Clínica do Instituto de Psicologia da Universidade de São Paulo para obtenção do título de Mestre em Psicologia.

Área de concentração: Psicologia Clínica

Aprovado em :

Banca examinadora

Prof. Dr.

Instituição Assinatura

Prof. Dr.

Instituição Assinatura

Prof. Dr.

Instituição Assinatura

Prof. Dr.

Instituição Assinatura

Prof. Dr.

Instituição Assinatura 
V

Aos meus pais. À Juliana, minha companheira e grande amor. 


\section{AGRADECIMENTOS}

À minha orientadora Dra. Maria Lúcia de Araújo Andrade, por sua perseverança e insistência em me manter no rumo do trabalho de escrita.

Ao Dr. Christian e à Dra.Isabel, por suas ricas contribuições e apontamentos durante o exame de qualificação.

À Juliana, que se manteve ao meu lado durante as horas mais difíceis e longas, além de ser fonte de inspiração.

À minha família, que acreditou em mim dando apoio e amor constantemente.

A todos os operadores do direito e funcionários que trabalharam no JECRIFAM, com quem enfrentei lado a lado as dificuldades da sustentação do serviço debatido nesta dissertação e sem os quais nada disso seria possível.

Aos estagiários e ao psicólogo voluntário, que suaram a camisa ao meu lado no dia-a-dia do Setor de Psicologia do JECRIFAM.

À Dra. Carmem Lúcia da Silva, pela aposta e apoio, necessários para a sustentação do serviço discutido nesta dissertação.

À Lívia, pela condução da minha análise durante todo esse percurso de trabalho no Fórum Criminal, espaço que foi fundamental para que eu pudesse sustentar o serviço em debate nesta dissertação.

À Dra. Helena Bicalho e ao Laboratório de Psicanálise "Jacques Lacan" do IP-USP, por todas as contribuições fundamentais para a formação deste analista.

Ao pessoal do Laboratório Sujeito e Corpo do IP-USP, pelas ricas contribuições.

À Marta e ao pessoal do instituto Therapon Adolescência, pelo apoio e rica reflexão oferecida.

À USP, aos professores e aos colegas das matérias da Pós-graduação, por suas sugestões oportunas. 
Resumo

AZEVEDO, José Eduardo Assunção - Psicanálise e Justiça Criminal: questões e posicionamentos sobre uma clínica da violência doméstica, 2008, 144 p. Dissertação (Mestrado). Instituto de Psicologia, Universidade de São Paulo.

A presente dissertação apresenta relatos e reflexões sobre o percurso de implementação e desenvolvimento do serviço de atendimento clínico psicológico psicanalítico a famílias em situação de violência doméstica usuárias do Juizado Especial Criminal da Família, JECRIFAM, no Fórum Criminal Central de São Paulo (Barra Funda). Este serviço foi desenvolvido no modelo de projeto-piloto, fruto de uma parceria entre Poder Executivo (Secretaria da Justiça e da Defesa da Cidadania) e Poder Judiciário (Tribunal de Justiça) em âmbito estadual. A pesquisa realizada e o modelo de serviço ora discutido têm por referência a psicanálise de orientação lacaniana. Por levantar e colocar em pauta especificidades relevantes à reflexão acerca desse percurso, esta dissertação oferece subsídios para a discussão de alguns limites e potencialidades do oferecimento de um dispositivo de escuta clínica para casos de violência doméstica no contexto da Justiça Criminal. Tal discussão é realizada a partir da questão: que escuta cabe oferecer neste contexto? Para tal são apresentados recortes de casos atendidos. A fim de melhor circunscrever o campo no qual se engendrou o serviço, são apresentados também: os encontros com outros agentes institucionais, as estatísticas do serviço e questões relativas aos encontros entre agentes institucionais e cidadãos usuários da Justiça Criminal. A partir destas apresentações é estabelecida breve discussão acerca de algumas contingências ao exercício da cidadania neste contexto, às quais o discurso psicanalítico parece agregar valores.

Palavras-chave: psicanálise; Justiça Criminal; violência doméstica. 


\section{Abstract}

AZEVEDO, José Eduardo Assunção - Psychoanalysis and Criminal Justice: questions and positions on a clinic service to domestic violence, 2008, 144 p. Dissertação (Mestrado). Instituto de Psicologia, Universidade de São Paulo.

This paper presents speeches and reflections on implementation and development of a psychological clinic service to families in domestic violence situation users of JECRIFAM, institution of the Court of the Criminal Justice, in São Paulo. This service has been developed in a pilot-project model, based on a political State articulation. The research and this service are based on Lacan's psychoanalytic propositions. The reflection on "path" (way) gives recourses to debate some of the clinic listening device limits and potentials in Court of the Criminal Justice context, especially about domestic violence. This debate has a central question: Which listening "fits" on this context? (or: Which listening belongs to its context?) Parts of some cases are presented. A field's better understanding is also presented: the meeting to others institutional agents, the statistics and some questions about the citizen approaches to the Court of the Criminal Justice. There is a short debate on the psychoanalysis possible contributions on the contingencies of the exercise of citizenship rights, based on these presentations.

Key words: Psychoanalysis; criminal law; domestic violence. 
SUMÁRIO

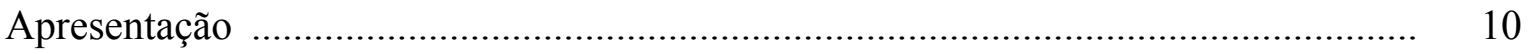

Dos motivos e objetivos desta dissertação ……................................................... 13

Referenciais teórico-metodológicos da pesquisa $\quad$.................................................. 16

PARTE I - PRIMEIROS MOMENTOS NO FÓRUM CRIMINAL ......................... 21

Contexto político da implementação do Setor de Psicologia ……................................. 22

Da fundação e implementação do serviço de psicologia no JECRIFAM $\quad$................... 26

Artigos específicos do Código Penal (129, 130-136, 146-149) nos quais se

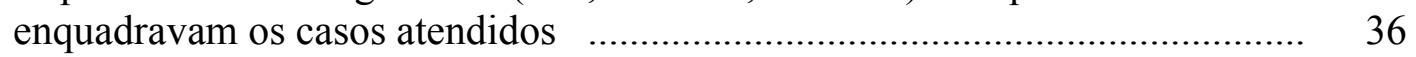

Estágio e Voluntariado .................................................................................... 38

Algumas referências do serviço implementado $\quad$....................................................... 41

Condições gerais de trabalho e supervisão $\quad$............................................................... 56

PARTE II - RELATOS DO PERCURSO DENTRO DO FÓRUM ............................ 57

O modelo de serviço implementado ..................................................................... 58

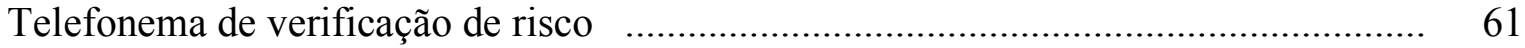

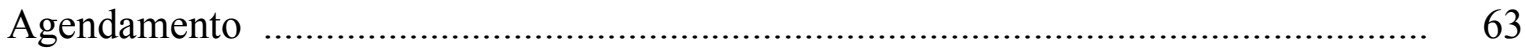

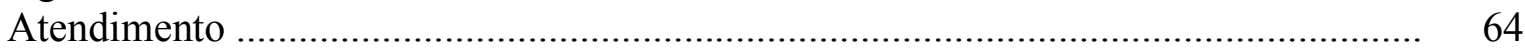

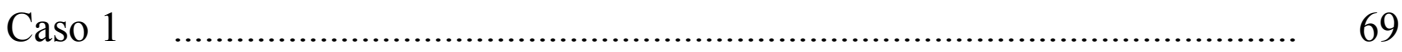

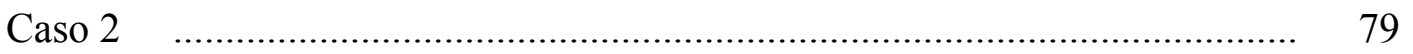

Caso $3 \quad$.................................................................................. 87

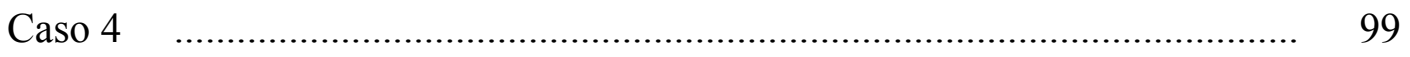

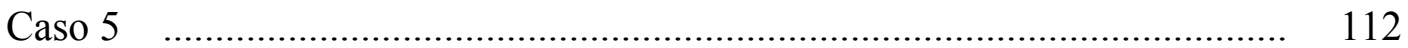

Encontros e desencontros dos usuários do JECRIFAM com a Justiça $\quad$....................... 117

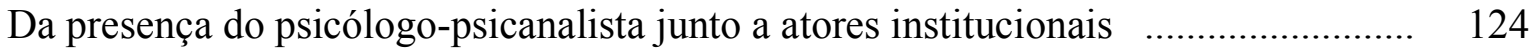

Sobre as estatísticas atuais ............................................................................ 127

PARTE III - CHEGANDO A UM FINAL .............................................................. 133

Cenário interinstitucional e político ao longo da existência do

Setor de Psicologia do JECRIFAM e a situação atual ................................... 134

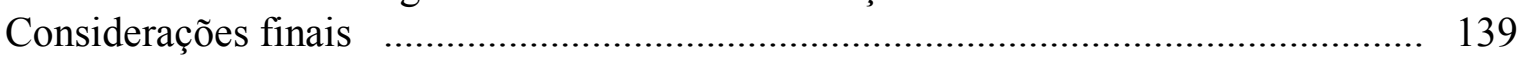

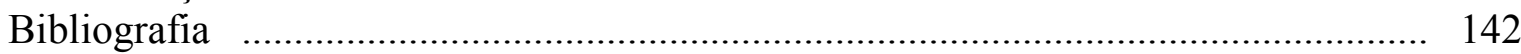




\section{Apresentação}

Esta dissertação apresenta um modelo possível de atendimento psicológico com referência psicanalítica dentro do Tribunal de Justiça Criminal a partir do percurso de implementação e desenvolvimento de um serviço. Esta apresentação é atravessada por alguns debates sobre implicações éticas, limitações e possibilidades de um serviço neste contexto. Tais debates têm como principal referencial teórico-metodológico a Psicanálise sob uma orientação lacaniana, sendo utilizadas principalmente as proposições de Freud e Lacan. A relevância deste trabalho tem como suporte o êxito do serviço implementado, que já vem sendo utilizado como referência para se pensar outras políticas públicas.

O modelo de atendimento psicológico-psicanalítico apresentado cujos resultados possibilitaram a realização desta pesquisa qualitativa teve lugar no Fórum Criminal Central de São Paulo, na Barra Funda. Mais especificamente: o modelo implementado no Juizado Especial Criminal da Família, JECRIFAM, onde foi constituído um Setor de Psicologia, responsável direto pelo atendimento a famílias em situação de processo criminal por violência doméstica. Neste Setor de Psicologia foram realizados atendimentos a mais de 600 famílias paulistanas que recorreram à Justiça a fim de obterem uma resposta legal acerca de fatos violentos ocorridos dentro de seus lares, em um período de três anos de funcionamento. Este Setor de Psicologia contava com um único funcionário, um psicólogo-psicanalista, autor desta dissertação.

O texto apresenta um percurso acerca das dificuldades, impedimentos, conquistas e questões suscitadas durante o desenvolvimento concreto deste serviço. Há a expectativa de transmitir alguns recursos e advertências a quem estiver envolvido com situações próximas ou análogas, além da proposição de um convite à discussão das temáticas afins. 
Por este motivo parece relevante adiantar os principais temas apresentados e discutidos na presente dissertação, a saber:

- Um modelo de atendimento possível neste contexto;

- Algumas características do contexto no qual se engendrou este serviço;

- Encontros do psicólogo-psicanalista com os outros atores institucionais e com a burocracia da instituição judiciária criminal;

- Referenciais teóricos relevantes para a sustentação do serviço;

- Algumas limitações éticas e legais;

- Contexto político no qual se sustentou a pertinência de um serviço nestes moldes;

- Características mais comumente encontradas no discurso dos usuários do serviço, principalmente quanto ao encontro com a Justiça.

No presente trabalho há a opção de apresentação das principais referências em jogo sobre as quais é realizada uma reflexão ética. Para além da proposição de algumas compreensões e entendimentos há a construção de questões e posicionamentos relevantes para a prática de um psicólogo-psicanalista no âmbito da Justiça Criminal.

Aqueles que estão mais informados sobre o funcionamento da Justiça Criminal e da legislação vigente podem estar se fazendo algumas perguntas: mas afinal, não mudou a Lei que incide sobre os crimes de violência doméstica? O JECRIFAM ainda existe? Este modelo de política pública ainda está vigendo?

Tais questões encontram respostas no texto que se segue, mas considero possível já adiantar alguns pontos. A Lei que dá as diretrizes do funcionamento da instituição judiciária para casos de violência doméstica realmente mudou para casos nos quais a mulher figura como vítima o que, no entanto, não impediu a continuidade do serviço, mas trouxe algumas mudanças na burocracia de comunicação com as varas. Ocorreu que o JECRIFAM foi extinto, 
e os casos que tratam da violência familiar foram redistribuídos entre outras Varas. Os processos nos quais não é a mulher a vítima foram assumidos pelo JECRIM, que continuou endereçando tais casos ao serviço agora oferecido pelo CRAVI do Fórum Criminal, fundado em março de 2007, cujo trabalho oferecido foi desenvolvido a partir do modelo ora apresentado. Nos casos em que a vítima é uma mulher, os processos vêm sendo distribuídos para as varas criminais comuns, até que seja instalado o Juizado específico (previsto por Lei). O encaminhamento destes casos para o CRAVI opera de uma maneira diferente de acordo com a Vara (são 36 Varas Criminais no Fórum) e não parece cabível a explicação dessas particularidades neste trabalho.

A situação atual marca o começo de uma nova configuração que já recebe novamente casos de violência doméstica nos quais a mulher figura como vítima. O modelo de política pública discutido nesta dissertação se presta, portanto, à função de uma das referências para o estabelecimento do modelo atualmente em exercício no CRAVI. 


\section{Dos motivos e objetivos desta dissertação.}

O presente trabalho tem por objetivo apresentar pesquisa qualitativa sobre uma política pública, o serviço de atendimento psicológico-psicanalítico para casos de violência doméstica no Juizado Especial Criminal da Família, JECRIFAM, do Fórum Criminal Central de São Paulo, Fórum Criminal Ministro Mário Guimarães. Tal política pública foi partícipe de um movimento afirmativo dentro do espaço público que propõe a garantia de que a fala de vítimas da violência urbana seja escutada pela Justiça, posto que o modelo vigente de funcionamento da Justiça Criminal no Brasil foca suas atenções principalmente no autor dos fatos (ou réu) relegando um lugar em segundo plano para as vítimas ou aqueles que demandaram ajuda da Justiça. Existe um consenso entre os operadores do direito de que atualmente a Justiça Penal é voltada quase que exclusivamente para os autores do fato, restando um lugar secundário para as vítimas. Em parte isso se dá pelo próprio modelo um tanto antigo do nosso Código Penal, em vigor há quase 70 anos, desde 1940.

A pesquisa consistiu em: leitura do campo institucional; leitura e discussão dos prontuários de casos atendidos; e busca de referenciais teóricos que esclarecessem limitações e potencialidades do serviço. São apresentadas discussões sobre: as práticas psicológicas desenvolvidas e possíveis contribuições da Psicanálise especificamente para este contexto. Toda a discussão é sustentada pela apresentação de alguns recortes do percurso de desenvolvimento histórico e político deste serviço.

Essas discussões giram em torno de um questionamento acerca das potencialidades e limites do oferecimento de escuta psicológica-psicanalítica no âmbito judiciário criminal a partir do relato concreto de uma experiência realizada, gravitando em torno da questão: qual escuta cabe oferecer neste contexto? 
Visando circunscrever o campo no qual se sustenta esta questão e discutir possibilidades e limitações, são apresentados debates entre: referências teórico-metodológicas relevantes a partir de recortes das sessões, o funcionamento das leis vigentes e as principais relações institucionais, a fim de possibilitar uma inserção no campo de trabalho em que se engendra o serviço. Esta contextualização pretende ofertar subsídios e recursos sobre algumas particularidades do modelo de serviço oferecido.

A apresentação das dificuldades encontradas pelo psicólogo-psicanalista soma a este trabalho de contextualização uma possibilidade de compreensão de alguns limites do serviço oferecido. As particularidades destes limites fazem função de referência para o entendimento das possibilidades de trabalho de um clínico neste contexto.

São apresentadas reflexões sobre a prática clínica a partir da apresentação de alguns casos. Todas as considerações ficarão restritas à abordagem escolhida, a fim de restringir qualitativamente os recortes apresentados. Também um esclarecimento sobre esta abordagem é apresentado à frente.

É realizada uma breve leitura do contexto político no qual emergiu esta prática, com a divulgação de estatísticas oficiais, de alguns números do serviço e do percurso das demandas portadas pelos atores institucionais diretamente ligados ao estabelecimento do serviço.

Uma das metas da pesquisa de mestrado foi a possibilidade de precisar e referenciar epistemologicamente este modelo de intervenção a partir de debate e pesquisa acadêmicos. A idéia era aprimorar o modelo de intervenção e consolidar seu discurso, a fim de, justamente, possibilitar seu aperfeiçoamento teórico visando consolidar sua consistência para o momento de passagem da política pública: de projeto-piloto a programa estadual.

Neste sentido, alguns referenciais teóricos e o modelo de serviço oferecido, foram discutidos nas matérias cursadas durante o mestrado. Também foi apresentado um caso clínico para discussão em reunião do Laboratório Sujeito e Corpo, sob orientação da 
professora doutora Maria Lúcia de Araújo Andrade, quando ocorreu discussão sobre o atendimento realizado e o campo, o que permitiu localizar algumas pertinências e limitações.

O trabalho de atendimento dentro do Fórum Criminal é aqui apresentado com o objetivo de abrir/ampliar o campo de debates sobre algumas possibilidades e restrições da contribuição da Psicanálise às políticas públicas, especificamente às de defesa da cidadania e dos Direitos Humanos, através deste recorte aqui discutido. Tais restrições, no entanto, podem ser tomadas como referência para a afirmação de que a presente pesquisa não pretende de forma alguma promover ou ofertar determinada posição política definitiva ou absoluta, não pretendendo apresentar verdade final sobre as intrincadas dinâmicas políticas a que estão constantemente referidos espaços públicos e/ou Políticas Publicas. Trata-se, portanto, de apresentar elementos importantes para que o leitor possa se localizar em relação às temáticas discutidas.

Por fim, a presente dissertação pretende transmitir algumas considerações e referências psicanalíticas relevantes para profissionais da psicologia que realizam trabalho clínico que envolva Justiça Criminal e/ou violência doméstica, principalmente no que diz respeito a posicionamentos éticos e políticos. 


\section{Referenciais teórico-metodológicos da pesquisa}

O modelo desta dissertação é monográfico, uma vez que problematiza campo, questão e tema, promovendo debates e explicitando o percurso pessoal do pesquisador, sem a preocupação de realizar, ao seu término, uma conclusão objetiva, mas propondo considerações e oferecendo posicionamentos, questões e recursos. Por esses motivos o conhecimento gerado e transmitido pela presente dissertação se pretende útil e ao mesmo tempo compreensivo.

O principal referencial teórico-metodológico do serviço, assim como o da pesquisa realizada e da presente dissertação, é a Psicanálise de orientação lacaniana. As duas principais referências da Psicanálise utilizadas são, portanto: Freud e Lacan. Como sabemos a Psicanálise, atualmente, conta com diversas escolas e instituições clínicas que se propõem a diferentes leituras e entendimentos conceituais. Ao falarmos de Psicanálise nesta dissertação estaremos referidos principalmente, e na maioria dos casos apenas, à Psicanálise de orientação lacaniana. Para isso são utilizadas referências diretas a textos de Lacan e de alguns de seus comentadores ou autores que seguem sua linha de trabalho, além da retomada de passagens de Freud fundamentais à pesquisa desenvolvida.

Os procedimentos utilizados para a realização da pesquisa e a escrita da dissertação são: observação em situação, observação participante, análise de campo, análise de casos clínicos e promoção de diálogos. Algumas limitações impostas pela utilização destes instrumentos podem ser elencadas:

- Dado que o pesquisador é o psicólogo responsável pela proposição do projeto do Setor de Psicologia do JECRIFAM, implementação do mesmo e 
realização dos atendimentos clínicos que são objeto de análise nesta dissertação fica a questão: o quanto este pesquisador pôde realizar um distanciamento crítico em relação ao material de sua pesquisa?

Sendo a Psicanálise a principal referência clínica que embasou os atendimentos analisados por essa pesquisa, quais as conseqüências/efeitos e limitações de submeter este modelo clínico proposto a uma análise novamente referida à Psicanálise?

A apresentação dos debates no texto da dissertação utiliza, como método, a apresentação dos diferentes discursos (da psicanálise, dos operadores do Direito ou dos usuários, por exemplo) e alguns frutos possíveis do encontro entre tais discursos. $\mathrm{O}$ pesquisador participou diretamente destes encontros. A proposta do modelo monográfico que implica o percurso do pesquisador tem como finalidade evitar toda sorte de equívocos e/ou mal-entendidos que poderiam surgir de uma tentativa de colocar-se como observador externo aos diálogos apresentados.

Os casos apresentados nesta dissertação consentiram na utilização de seus prontuários para pesquisa. Mesmo assim algumas limitações se impõem, apesar do consentimento dos usuários, uma vez que as falas dirigidas ao Setor de Psicologia estão resguardadas por duplo sigilo: o Conselho Federal de Psicologia em seu Código de Ética propõe como diretriz dos serviços de atendimento o sigilo profissional e, somando-se a este sigilo da profissão de psicólogo, é preciso já adiantar que os casos atendidos pelo Setor de Psicologia correm em segredo de Justiça, ou seja, qualquer material concreto dos casos que possa vir a identificar algum dos partícipes não deve ser exposto fora do contexto do Judiciário. 
Do Código de Ética Profissional do Psicólogo em vigor temos os seguintes artigos que dão as diretrizes de posicionamento possível para o profissional:

Art. $\mathbf{6}^{\circ}$ - O psicólogo, no relacionamento com profissionais não psicólogos: b) Compartilhará somente informações relevantes para qualificar o serviço prestado, resguardando o caráter confidencial das comunicações, assinalando a responsabilidade, de quem as receber, de preservar o sigilo.

Art. $9^{\boldsymbol{o}}-\dot{E}$ dever do psicólogo respeitar o sigilo profissional a fim de proteger, por meio da confidencialidade, a intimidade das pessoas, grupos ou organizações, a que tenha acesso no exercício profissional.

Art. 10 - Nas situações em que se configure conflito entre as exigências decorrentes do disposto no Art. $9^{\circ} e$ as afirmações dos princípios fundamentais deste Código, excetuando-se os casos previstos em lei, o psicólogo poderá decidir pela quebra de sigilo, baseando sua decisão na busca do menor prejuizo.

Parágrafo único - Em caso de quebra do sigilo previsto no caput deste artigo, o psicólogo deverá restringir-se a prestar as informações estritamente necessárias.

Art. 11 - Quando requisitado a depor em juízo, o psicólogo poderá prestar informações, considerando o previsto neste Código.

Art. 12 - Nos documentos que embasam as atividades em equipe multiprofissional, o psicólogo registrará apenas as informações necessárias para o cumprimento dos objetivos do trabalho.

Art. 13 - No atendimento à criança, ao adolescente ou ao interdito, deve ser comunicado aos responsáveis o estritamente essencial para se promoverem medidas em seu beneficio.

Art. 14 - A utilização de quaisquer meios de registro e observação da prática psicológica obedecerá às normas deste Código e a legislação profissional vigente, devendo o usuário ou beneficiário, desde o início, ser informado.

Art. 16 - O psicólogo, na realização de estudos, pesquisas e atividades voltadas para a produção de conhecimento e desenvolvimento de tecnologias:

a) Avaliará os riscos envolvidos, tanto pelos procedimentos, como pela divulgação dos resultados, com o objetivo de proteger as pessoas, grupos, organizações e comunidades envolvidas;

b) Garantirá o caráter voluntário da participação dos envolvidos, mediante consentimento livre e esclarecido, salvo nas situações previstas em legislação específica e respeitando os princípios deste Código;

c) Garantirá o anonimato das pessoas, grupos ou organizações, salvo interesse manifesto destes.

A partir desta referência, todo material de casos apresentado na presente dissertação sofreu as seguintes alterações, de forma a possibilitar a transmissão do modelo clínico sem comprometimento da confidencialidade: os nomes próprios, lugares, instituições envolvidas (excetuando-se o JECRIFAM), e quaisquer outros dados que permitissem a identificação dos usuários foram alterados ou excluídos; significantes com uso muito particularizado que 
pudessem identificar usuários ou famílias foram "traduzidos" da melhor maneira possível para se manter a coerência dos percursos na instituição; algumas histórias de vida muito singulares tiveram situações substituídas por situações parecidas/análogas; e alguns dados foram simplesmente excluídos, ou por não serem relevantes à discussão ou por não ser possível alterá-los sem a perda da precisão e/ou sentido.

A paráfrase também apareceu como recurso operacional facilitador para esta tarefa. Uma questão que parecia ter status de problema impossível de resolver foi: o sentido que se pretende nestas "traduções" seria o sentido dos jogos de significado ou o sentido dos jogos de significantes? Haveria como sustentar ambos? A escolha variou de caso a caso, mas parece importante ressaltar que uma solução entre essas duas vertentes nem sempre foi possível. Desta forma, o movimento de expor o material de forma a impossibilitar a identificação dos usuários, pode gerar, em alguns pontos, uma sensação de incompletude no leitor.

O encaminhamento da questão-guia, qual escuta cabe oferecer neste contexto?, dáse pela proposição de reflexão a partir da apresentação de relatos, situações corriqueiras, posicionamentos possíveis e questões suscitadas. Este formato pretende circunscrever algumas particularidades desta escuta, partindo-se da consideração de que um trabalho psicanalítico clínico realiza-se sempre com uma configuração muito particular, própria: a cada caso, a cada contexto, a cada analista.

O debate acerca das particularidades do contexto considera tal contexto também em sua consistência historial, ou seja, parte-se da posição de que o encontro entre cidadãos e instituição judiciária está sempre submetido à ação do tempo e as transformações da Cultura. Desta forma sustentamos a proposição freudiana da necessária atenção ao momento da Cultura, implicando tal atenção a este percurso de construções e substituições de crenças e visões-de-mundo, que incidem diretamente sobre as formas possíveis de se relacionar com as instituições. Sobre esta temática a posição freudiana é que apesar destes movimentos 
observáveis na Cultura, toda sorte de visões-de-mundo supostamente ultrapassadas ainda hoje se atualizam expondo suas marcas, vale, então, retomar uma passagem de Análise Terminável e Interminável (FREUD, 1937):

De todas as errôneas e supersticiosas crenças da humanidade que foram supostamente superadas não existe uma só cujos resíduos não perdurem hoje entre nós, nos estratos inferiores dos povos civilizados ou mesmo nos mais elevados estratos da sociedade cultural. O que um dia veio à vida, aferra-se tenazmente à existência. Fica-se às vezes inclinado a duvidar se os dragões dos dias primevos estão realmente extintos. 


\section{PARTE I}

PRIMEIROS MOMENTOS NO FÓRUM CRIMINAL 


\section{Contexto político da}

\section{implementação do Setor de Psicologia}

Esta prática psicológica foi desenvolvida numa estrutura de projeto-piloto, fruto de uma parceria entre Poder Judiciário e Secretaria de Justiça e da Defesa da Cidadania do Estado de São Paulo. Tal parceria se realizou pela implementação e sustentação do Setor de Psicologia do JECRIFAM, desde a contratação do psicólogo em dezembro de 2003, com a implementação e operação do Setor de Psicologia de março de 2004 até fevereiro de 2007. Como projeto-piloto o Setor de Psicologia do JECRIFAM ficava referido ao Centro de Referência e Apoio à Vítima, CRAVI, por determinação do Secretário de Justiça à época de sua implementação, Dr. Alexandre de Moraes.

CRAVI é o programa da Secretaria de Justiça e da Defesa da Cidadania em parceria com a Secretaria Especial dos Direitos Humanos, da Presidência da República, responsável por implementar a Política Nacional de Atendimento à Vítima (de 1997) em âmbito estadual. O CRAVI oferecia atendimento psicológico, social e jurídico às vítimas indiretas de crime doloso contra a vida, especificamente, homicídio e latrocínio. Além disso, sua realização se dava a partir de parcerias com ONGs (Organizações Não-Governamentais). Durante o período no qual operou o Setor de Psicologia do JECRIFAM, o CRAVI tinha parceria com a ONG Instituto Therapon Adolescência e, por apenas em alguns meses de 2005, com a ONG Instituto São Paulo Contra a Violência.

O programa CRAVI serviria como referência a este projeto-piloto no sentido de portar a direção política pretendida pela Secretaria de Justiça e da Defesa da Cidadania, contratar pessoal, dar suporte material e técnico para a realização do serviço e mediar a relação deste projeto-piloto com o Gabinete do Secretário. O Setor de Psicologia do JECRIFAM deveria funcionar como um "braço" do CRAVI dentro do Tribunal de Justiça. 
No entanto a realização de tal referência, que operava no nível do suporte legal da realização do projeto-piloto, com freqüência vacilou. A coordenação do CRAVI durante este período sustentou que, pela diferença da temática (crime contra a vida versus violência doméstica), não interessava ao referido programa possuir tal "braço". O discurso era que este projeto-piloto havia sido uma "imposição do Secretário da Justiça" e que "não fazia sentido com as diretrizes do programa". Foi assumida, assim, a posição de que o projeto-piloto ora apresentado era "não-CRAVI", o que possibilitou um primeiro momento de aparente desresponsabilização das atribuições e criou sérias dificuldades de comunicação entre o projeto-piloto e o referido programa e, pior ainda, isolou qualquer possibilidade de comunicação entre política pública (Setor de Psicologia) e gestor público (gabinete) por dois anos.

O Setor de Psicologia do JECRIFAM partiu, portanto, de uma posição um pouco esquisita, uma vez que podia contar apenas com uma das duas referências institucionais que o constituíam, dado que a comunicação com o Tribunal de Justiça era diária, tendo como interlocutores: a direção do juizado (ao cargo de uma juíza quando de sua fundação), os promotores do Ministério Público Estadual que atuavam pelo JECRIFAM e alguns advogados dativos da Procuradoria de Assistência Judiciária (atualmente transformada em Defensoria Pública do Estado).

O fato de esta política pública ser estruturada em um modelo de projeto-piloto implicava que a condução de tal projeto se daria pela afirmação de um campo de realização experimental, com a finalidade de encontrar possibilidades de um serviço que contribuísse para a instituição judiciária e para os cidadãos usuários. Este modelo também tem por característica ser uma política pública governamental. Há uma diferença entre política pública estatal e governamental, pois enquanto aquela é fundamentada em legislação - possuindo aparelhos, verba própria e funcionários contratados via concurso público - esta depende 
diretamente das iniciativas políticas dos gabinetes - recebendo repasse de verbas e tendo funcionários em cargos de comissão.

Por fim, parece também necessário lembrar o momento político no qual foi implementado o JECRIFAM. Em 2002 o projeto do JECRIFAM foi escrito por um desembargador do Estado de São Paulo. Naquele momento havia grande discussão publica acerca do funcionamento da Justiça frente a casos de violência doméstica nos quais a mulher figurava como vítima. O tema foi até representado em novela da Rede Globo, no horário nobre (novela das 8), na qual um marido espancava cotidianamente sua mulher (até com uma raquete de tênis). Na novela a personagem procurou a Justiça, mas o agressor "safou-se" com o pagamento de cesta-básica.

A solução de prestação pecuniária (cesta-básica, doação etc) para casos de violência marital contra mulher gerou inúmeros protestos das organizações e movimentos pelos direitos da mulher e/ou Direitos Humanos. Também a imagem da Justiça parecia publicamente “arranhada". Então, neste ano de 2002, a fim de responder aos protestos e sugestões que lhe eram remetidos, o Tribunal de Justiça do Estado de São Paulo começou o movimento de implementação do JECRIFAM, no intuito de oferecer serviço particularizado para estes casos. É importante lembrar que a Lei que cria os Juizados Especiais Criminais (Lei Federal 9.099) é de 1995, porém o julgamento dos casos que se enquadram em tal Lei correram em Vara Criminal comum até a implementação do JECRIFAM em 2003.

A Lei 9.099/95 propõe a criação de Juizados Especiais Cíveis e Criminais. Na vertente da Justiça Criminal, o Juizado deveria julgar casos definidos como de "menor potencial ofensivo". Esta Lei foi criada a fim de desburocratizar o trâmite judicial, ou seja, visava acelerar o tempo dos processos em casos considerados menos graves, além de possibilitar acordos (transações) e penas alternativas à restrição de liberdade. Para casos de crimes em 
família parecia uma alternativa viável posto que este maior espaço de fala (quando da tentativa de acordo) possibilitaria um melhor entendimento das dinâmicas em jogo.

Ocorria que ao tratarem desta matéria na Vara Criminal comum os atores institucionais muitas vezes optavam por acordos rápidos com o réu, que de bom grado aceitavam a prestação pecuniária (cesta ou doação). Muitos atores institucionais destas Varas consideravam a violência doméstica como um crime "menor" em relação aos outros que lhes eram encaminhados (tráfico, crime organizado, latrocínio, violência sexual etc). A Justiça Criminal parecia poder operar sem ao menos ouvir a vítima à época. Logicamente este tipo de resolução começou a ser questionado e criticado.

O JECRIFAM pretendeu, durante seu funcionamento, criar novas formas do trato da matéria, possibilitando espaço para um debate mediado entre vítima e réu, nos casos em que a vítima se sentia confortável para tal. Este espaço foi campo propício para a viabilização da implementação de um Setor de Psicologia nos moldes que são apresentados nessa dissertação. 


\section{Da fundação do serviço de psicologia no JECRIFAM}

O Juizado Especial Criminal da Família do Fórum da Barra Funda foi inaugurado em outubro de 2003, funcionando sob a Lei 9.099/95, com a finalidade de atender os casos de crimes de "menor potencial ofensivo" ocorridos dentro de grupos familiares. "Menor potencial ofensivo" é a definição para crimes com pena de restrição de liberdade inferior ou igual a dois anos (Lei 10.259/01). À frente é apresentada a tipificação dos crimes pertencentes a esta categoria, o que permite compreender o campo de usuários do JECRIFAM também a partir dos fatos em julgamento.

Foi idealizada a criação de um núcleo psicossocial para dar suporte ao funcionamento do Juizado, conforme previsto no projeto do mesmo. Para tal firmou-se um convênio entre Tribunal de Justiça e Secretaria de Justiça e da Defesa da Cidadania do Estado de São Paulo, no qual esta Secretaria se responsabilizaria por constituir a equipe de tal núcleo e dar suporte material, enquanto que o Tribunal de Justiça ofereceria salas e mobília.

Em dezembro de 2003 foi contratado um único psicólogo, o autor desta dissertação, para o serviço, dois meses após a inauguração do próprio JECRIFAM, apesar do projeto original prever a contratação de equipe de psicólogos e assistentes sociais (note-se o plural). O Juizado, assim como as outras Varas, é dirigido por um juiz e no momento de implantação deste Juizado a direção estava a cargo de uma juíza, a Meritíssima Doutora Carmen Lúcia da Silva.

A fim de dar referência ao psicólogo contratado em relação às expectativas do Juizado, esta diretora escreveu-lhe uma carta em dezembro de 2003, enviada por e-mail, que se segue:

Resumo das pretensões jurídicas, sociais e psicológicas do Juizado Especial Criminal da Família - JECRIFAM:

Consideram-se infrações de menor potencial ofensivo aquelas em que a pena máxima prevista não exceda dois anos. Entre tais infrações estão os crimes de lesões corporais leves e de ameaça. Muitos desses delitos são praticados no âmbito doméstico (pais e filhos, avôs, netos, 
tios e sobrinhos, marido e mulher, companheiros, namorados, etc.), caracterizando a chamada violência doméstica. Para melhor atender às pessoas autoras elou vítimas de delitos de tal natureza, o Tribunal de Justiça do Estado de São Paulo criou o JUIZADO ESPECIAL CRIMINAL DA FAMÍLIA - JECRIFAM. A iniciativa do Tribunal de Justiça está ajustada ao Artigo 245 da Constituição do Brasil, que prevê assistência aos herdeiros e dependentes carentes de pessoas vitimadas por crime doloso, e ao Artigo 278, da Constituição do Estado de São Paulo, que prevê a criação e manutenção de serviços de prevenção, orientação, recebimento e encaminhamento de denúncias referentes à violência; instalação e manutenção de núcleos de atendimento especial para vítimas de violência, incluindo a criação de serviços jurídicos de apoio às vítimas, integradas a atendimento psicológico e social. A finalidade do JUIZADO ESPECIAL CRIMINAL DA FAMÍLIA é, num primeiro momento, a prestação de atendimento psicológico, jurídico e social à vítima e a familiares de vítimas de violência; identificar os perfis de violência atual e formas de prevenção; identificar e tentar reduzir os efeitos traumáticos provenientes da violência sofrida pela vítima e por seus próprios familiares, entre eles o autor da infração; colaborar para a ruptura de ciclos e códigos de violência existentes no núcleo familiar; auxiliar na reconstrução das famílias em que aflorou a violência doméstica; valorizar o papel da vítima no procedimento criminal e encontrar a melhor medida sócio-educativa a ser aplicada ao autor da infração, incluindo a mais perfeita execução da mesma.

MM. Dra. Carmen Lúcia da Silva.

A partir desse posicionamento começaram os trabalhos do psicólogo. Juntamente com a juíza diretora foi tomada a decisão de se realizarem entrevistas com a população usuária do JECRIFAM no momento diretamente anterior às audiências já agendadas. Esperava-se que tais entrevistas pudessem dar subsídios para se pensar um modelo de serviço para o psicólogo.

Ocorria que ao chegarem para as audiências era oferecida aos grupos familiares, ou individualmente, se assim fosse a vontade das partes do procedimento judiciário, a possibilidade de conversar com o psicólogo do Juizado. Nos meses de dezembro de 2003, janeiro e início de fevereiro de 2004 foram entrevistadas 46 famílias.

Os temas gerais que atravessavam a grande maioria das entrevistas eram: o(s) motivo(s) da representação (a vontade de que uma queixa se torne ação judicial), a(s) expectativa(s) em relação à Justiça, a situação atual e por que quiseram falar com o psicólogo. 
Faz-se importante ressaltar que para a população entrevistada o encontro com o psicólogo era entendido como um atendimento psicológico. O trabalho oferecido à população nesta fase era definido como "atendimento psicológico, cujo produto das entrevistas será base de uma pesquisa, que servirá para definirmos um modelo de atendimento para a população usuária do JECRIFAM".

O material destas entrevistas realmente serviu como base para uma pesquisa qualitativa que apontou para os seguintes aspectos:

- A maioria dos casos era referente à violência dentro dos casais, heterossexuais, nos quais a mulher figurava como vítima.

Havia, ainda, alguns poucos casos de violência entre irmãos, entre gerações (pais com filhos ou vice-versa), ou em casais nos quais o homem figurava como vítima (um caso). A escolaridade declarada dos entrevistados apresentou: dois grandes grupos, um sem escolaridade ou com formação até a $6^{\mathrm{a}}$ série do $1^{\circ}$ grau e outro com formação até o término do $2^{\circ}$ grau, e um pequeno grupo com poucos casos que tinham terceiro grau completo ou incompleto. Quanto às classes sociais não houve material suficiente para uma leitura do campo.

- Os cidadãos em geral estavam pouco, ou mal, informados sobre as possibilidades de resolução judiciária ao chegarem para a audiência.

Na maioria esmagadora dos casos o momento diretamente anterior à audiência era descrito como ansiógeno (palavras como "ansiedade", "angústia", "medo" e "nervoso" apareciam constantemente). Os usuários também narraram um vasto material de fantasias sobre as possibilidades de relação com a Justiça. Nestas narrativas a Justiça aparecia constantemente ocupando um lugar para o qual ao serem dirigidas demandas ocorreriam 
decisões que transformariam, ou que não transformariam, determinadas dinâmicas familiares e maneiras de ser. A Justiça parecia fazer a função de um limite, uma borda, à qual o cidadão poderia recorrer para obter tais mudanças, além de ser referência do que é justo.

- Os pedidos e queixas portados pelos usuários do serviço que tinham como referência os fatos em questão no procedimento judiciário, em geral pareciam não dialogar com as possibilidades de resolução judiciária dentro do contexto da Lei 9.099/95, ou seja, as expectativas das partes em relação ao procedimento judiciário eram diferentes do que tais procedimentos poderiam oferecer como resolução. $\mathrm{Na}$ maioria das vezes havia um pedido por parte destas mulheres que figuravam como vítimas de que seus companheiros, ou mesmo seus ex-companheiros, fossem mais carinhosos, menos violentos, fossem mais atenciosos com os filhos, ou ainda, que parassem ou diminuíssem a ingestão de bebidas alcoólicas.

É importante lembrar aqui que o procedimento judiciário no âmbito criminal limita-se ao julgamento de um determinado fato, supostamente violento e criminoso, já ocorrido. A função da Justiça é, portanto, realizar o julgamento acerca deste fato e reparar o que for de direito. Não cabe a um juiz, ou qualquer outro operador do Direito, determinar que alguém, mesmo se culpado de um crime, seja mais carinhoso, pare de beber, seja mais atencioso ou pare de ser violento. O que cabe aos operadores do Direito fazer quanto à questão da violência, para além de responsabilizar legalmente pela autoria de determinado fato e garantir uma reparação, é alertar quanto a possíveis sanções e penas cabíveis para o caso de reincidência ou novos fatos criminosos e tomar medidas protetivas para as vítimas diretas ou indiretas quando necessário. 
- Muitos casais se queixaram do não cumprimento de determinados contratos, formais e informais celebrados/combinados por ambos.

Muitos dos pares atendidos, conjunta ou individualmente, relataram grande descontentamento com a resposta de seu cônjuge (ou ex-cônjuge) em relação a combinações informais ou até em relação a contratos formalizados na Justiça, a maioria no âmbito Civil, como por exemplo: acordos de divórcio, visitas, férias dos filhos, pensão, alimentos, guarda, divisão de bens etc. Os entrevistados ainda apontavam ligação direta entre eventos violentos recentes e estes desencontros.

- Outras queixas e pedidos não diretamente relacionados à Justiça eram dirigidos ao psicólogo. Problemas de comunicação intrafamiliar, da educação dos filhos, da dinâmica do casal ou ex-casal, de finanças pessoais, etc, além de toda a gama de sintomas psicológicos e psicossomáticos.

Importante citar a repetida afirmação, por parte dos entrevistados, que em outros momentos da vida houve tentativas de dirigir tais pedidos e queixas a outras instituições, porém que não foram ouvidas, nem mesmo quando procuraram um órgão da Saúde Pública na busca por algum apoio psicológico. Cabe aqui uma questão: em casos nos quais da dinâmica familiar emergem sociopatias, desencontros contratuais, utilização de entorpecentes etc, é à Saúde Pública que a família deve reportar-se a fim de buscar transformações nesta dinâmica?

- Parecia fazer sentido para os entrevistados o oferecimento de escuta psicológica que visasse à elaboração de marcas psicológicas oriundas das experiências violentas, traumas etc.

Palavras como "cuidado", "apoio" e "reparação" emergiam da boca dos entrevistados associadas a "orgulho ferido", "humilhação", "submissão", "lesão”... 
- O funcionamento da burocracia institucional parecia poder operar quase que à revelia da subjetividade dos usuários da dita instituição.

Este ponto pareceu desde o início crucial uma vez que deixava em aberto a seguinte questão: é possível pensar em cidadania sem atentar para a subjetividade destes cidadãos? Ou ainda pior: que cidadania sem sujeito é essa na qual as formas mais pragmáticas parecem investir/insistir?

Esta percepção, e todas as questões que suscita, foram guardadas pois o psicólogopsicanalista entendeu que ainda era cedo para propor algum tipo de questionamento deste cenário, uma vez que este parecia ser o "jeito/estilo da casa” (Fórum) funcionar, sua ética. No entanto, a própria juíza diretora afirmava que uma das intenções do trabalho seria oferecer "um tratamento mais humano" do que o funcionamento comum da Justiça Criminal aos usuários do JECRIFAM. Como vimos na carta acima, o Juizado pretendia transformar um pouco o "jeito da casa", mas um dado já era perceptível desde o começo do trabalho: o Tribunal de Justiça, como instituição total, operava a partir de uma burocratização tal que as possibilidades de manifestação subjetiva pareciam não ter lugar. Este "tratamento mais humano" do Juizado parecia operar de forma "estranha" em relação ao resto da instituição, e aparentemente gerava incômodo.

Ao debater os resultados da pesquisa com a juíza diretora o psicólogo-psicanalista afirmou que talvez fosse interessante sustentar a realização de um trabalho junto a este profissional antes do momento da audiência, visando possibilitar que estes usuários pudessem melhor se localizar na relação com a Justiça que estavam estabelecendo e começar um trabalho de elaboração psíquica de possíveis traumas e lutos decorrentes da violência vivida. A juíza também relatou que os casos que passavam pela entrevista psicológica chegam à 
audiência "mais calmos e com mais clareza" sobre o que queriam, o que, de seu ponto de vista, constituía argumento consistente para a implementação de um trabalho prévio psicológico. Além disso, ambos concordaram que para alguns casos talvez fosse interessante uma quantidade maior de entrevistas antes do momento da audiência, a fim de possibilitar um trabalho maior junto ao psicólogo-psicanalista.

Um ponto debatido que referendava a realização deste trabalho era o senso comum de que em casos de família existiam dinâmicas interpessoais que ultrapassavam em muito às possibilidades de operacionalização da Justiça Criminal, mas que interferiam nos ritos.

Diante dos dados apresentados a juíza diretora decidiu estabelecer uma nova burocracia, na qual seria oferecida a possibilidade dos grupos familiares usuários do JECRIFAM participarem de um serviço psicológico antes do momento processual propriamente dito e decidiu batizar o serviço como fase pré-processual. A participação ficou definida como não obrigatória, mas optativa. A idéia era convidar tais famílias a participarem do trabalho junto ao psicólogo antes da data da audiência, de forma a possibilitar que algumas entrevistas pudessem ser agendadas, de acordo com a pertinência observada pelo profissional e a vontade de cada família, ou pessoa, envolvida.

Acho importante ressaltar o sentido empreendedor da M.ma Dra. Carmen Lúcia da Silva que, por seu ato, legitimou a criação de uma forma de trabalho clínico psicológico/psicanalítico no âmbito judiciário, na busca de desenvolvimento de práticas judiciárias no acesso e realização do cidadão à Justiça.

Neste mesmo período também foram realizadas duas Perícias Psicológicas, a pedido da Juíza. Chamou a atenção o fato de em ambos os casos haver ao menos um dos integrantes do litígio familiar que portava um discurso delirante, errático. Foi realizada a opção de não definir um tipo psíquico a partir de classificação nosográfica. Em ambos os casos o relatório da perícia apontou para as possíveis dificuldades que estes cidadãos teriam para o exercício da 
cidadania nos moldes pretendidos pelo rito jurídico em questão (a audiência de julgamento da queixa-crime) naquele momento. $\mathrm{O}$ modelo de funcionamento deste rito (audiência) pressupunha decisões articuladas a posicionamentos simbólicos o que, aparentemente, poderia ser vivido como algo invasivo/violento por estes sujeitos.

Ficou a impressão de que este dispositivo "audiência" não contava com os recursos necessários para se realizar frente a discursos delirantes, muito provavelmente porque fora pensado a partir de um ideal de homem que não abarca tal possibilidade. A possibilidade de um atendimento prévio junto a estas famílias parecia oferecer condições para que tais sujeitos se preparassem para a audiência por vir, assim como a discussão sobre tais perícias iniciou um debate frutífero sobre o funcionamento do rito em questão.

Três motivos sustentaram o posicionamento do psicólogo-psicanalista de que seu papel não seria, portanto, o de perito: em primeiro lugar parecia difícil sustentar concomitantemente um trabalho de "cuidado" psicológico e "preparação" para a audiência juntamente com a prática pericial, pois tal junção abriria campo para a emergência de paranóias e persecutoriedades; em segundo lugar a prática pericial poderia gerar alguma celeuma junto aos psicólogos peritos contratados pelo Tribunal de Justiça (que trabalham em outros Fóruns), dado que este psicólogo-psicanalista que aqui escreve é contratado por outra instituição (SJDC), o que poderia ser entendido como desvio de função; em terceiro lugar havia uma preocupação em afirmar uma direção de defesa da cidadania e laudos podem se prestar à função de argumento para pedidos de interdição judicial, ou seja, de apagamento (mesmo que temporário) das possibilidades de exercício da cidadania. À frente são apresentados pormenorizadamente recortes de casos nos quais foram percebidos discursos delirantes e algumas possibilidades de trabalho.

Com base nesta primeira pesquisa foi apresentado à coordenação do CRAVI o Projeto do Setor de Psicologia do JECRIFAM, que propunha este trabalho pré-processual, 
surpreendentemente aprovado sem discussões ou debates. Neste projeto estavam contidas as formas fundamentais da burocracia institucional e algumas propostas de um modelo interventivo, mas não havia ainda muita clareza quanto a que tipo de trabalho seria realizado, apenas apontava que a escuta a ser oferecida teria a Psicanálise como fonte na qual seriam procuradas referências. Uma motivação para a realização dessa pesquisa de mestrado foi justamente melhor precisar pertinência, possibilidades e limitações desta prática a partir de discussão acadêmica.

Em março de 2004 começou a funcionar o Setor de Psicologia do JECRIFAM. A fim de realizar a função de projeto-piloto foram criados modelos de relatórios, prontuários e estatísticas, com a finalidade de coleta de dados que pudessem embasar alguma proposição de política pública pertinente e coerentemente articulada. Todos os entrevistados eram avisados de que o material das entrevistas (triagens, acolhimentos, atendimentos, acompanhamentos, mediações etc) poderia ser utilizado em pesquisa sendo resguardados os nomes e qualquer referência que pudessem identificá-los. Alguns perguntavam sobre que tipo de pesquisa, com que finalidade etc. Apenas dois casos pediram para que não fosse utilizado o material de seus atendimentos em pesquisa, o que foi respeitado.

Como projeto-piloto havia também o compromisso de questionamento contínuo e experimentações de soluções alternativas, assim como articulações de rede que agregassem saberes e valores, de forma a contribuir com o desenvolvimento do projeto.

Havia alguma apreensão quando do início da implementação do Projeto do Setor de Psicologia, posto que a referência burocrática de forma alguma aliviava a preocupação quanto a como funcionaria a prática clínica. A referência da Psicanálise dava subsídios para a realização de escuta e intervenções a partir de uma ética bastante clara, mas o que ou quanto dessa ética caberia ser realizada dentro do Fórum Criminal? Prestaria-se como referência para o atendimento de famílias e casais dentro deste contexto no qual se atualizam os conflitos 
atuados? E outros casos de discurso delirante que porventura chegassem, que trabalho seria oferecido?

A falta de posicionamento e discussões no CRAVI, que se repetiu nos meses subseqüentes, foi fator fundamental para que o projeto-piloto ficasse referido mais consistentemente à coordenação do Juizado, tendo o psicólogo que apelar a outros laços em momentos de dúvida (análise pessoal, supervisão do consultório particular, colegas de profissão, professores, família etc), que vale ressaltar: foram muitos. O serviço parecia portado/legitimado unicamente pelo Tribunal de Justiça e a vontade profissional/pessoal do psicólogo. 


\section{Artigos específicos do Código Penal (129, 130-136, 146-149) nos quais se enquadravam os casos atendidos}

Esta parte visa realizar um breve sobrevôo sobre o Código Penal a fim de circunscrever a tipificação jurídica dos casos atendidos. A intenção é apresentar a população usuária dos serviços do Setor de Psicologia do JECRIFAM também a partir de Leis, referência fundamental do discurso e organização da burocracia institucional.

A Justiça trabalha, no âmbito criminal, a partir da tipificação do crime. Por tipificação podemos entender a associação de determinado fato ocorrido à lei escrita. Um réu só pode ser imputado de alguma penalização se o crime se enquadrar no previsto em Lei. Tipificação é, portanto, o trabalho de estabelecer a adequação de determinado fenômeno factual ao texto da Lei. Temos um exemplo disso quando alguém dá um chute em outrem e deste ato resta um hematoma, o que poderia ser tipificado como lesão corporal dolosa, Artigo 129. A proposição da ação penal cabe ao Ministério Público Estadual, portanto, ao Promotor de Justiça. Cabe, assim, a cada promotor se posicionar a respeito da tipificação de uma queixa-crime e requisitar uma audiência, na qual pode oferecer denúncia contra o réu se houverem provas suficientes. É necessário lembrar que a ação penal cabível ao JECRIFAM no caso de violência doméstica é condicionada à representação. Por este motivo, na audiência preliminar os operadores do Direito colhem a manifestação da pessoa que fez a queixa, ou seu representante legal, acerca de seu posicionamento quanto sua vontade de que aquele caso vire, ou não, ação penal.

A tabela abaixo traz o recorte jurídico dos usuários do JECRIFAM, a Partir do Código Penal, pela tipificação dos crimes que deram origem aos Termos Circunstanciados de Ocorrência. O texto foi retirado do Código Penal, atualizado, no sítio virtual da Presidência da República, http://www.planalto.gov.br/ccivil_03/Decreto-Lei/Del2848.htm: 


\begin{tabular}{|c|c|c|}
\hline \multicolumn{2}{|r|}{ Artigo } & Descriçãa \\
\hline 129 & Lesão corporal & $\begin{array}{l}\text { Ofender a integridade corporal ou a saúde de } \\
\text { outrem. }\end{array}$ \\
\hline 133 & Abandono de incapaz & $\begin{array}{l}\text { Abandonar pessoa que está sob seu cuidado, } \\
\text { guarda, vigilância ou autoridade, e, por qualquer } \\
\text { motivo, incapaz de defender-se dos riscos } \\
\text { resultantes do abandono. }\end{array}$ \\
\hline 134 & $\begin{array}{l}\text { Exposição ou abandono de } \\
\text { recém-nascido }\end{array}$ & $\begin{array}{l}\text { Expor ou abandonar recém-nascido, para ocultar } \\
\text { desonra própria. }\end{array}$ \\
\hline 136 & Maus tratos & $\begin{array}{l}\text { Expor a perigo a vida ou a saúde de pessoa sob sua } \\
\text { autoridade, guarda ou vigilância, para fim de } \\
\text { educação, ensino, tratamento ou custódia, quer } \\
\text { privando-a de alimentação ou cuidados } \\
\text { indispensáveis, quer sujeitando-a a trabalho } \\
\text { excessivo ou inadequado, quer abusando de meios } \\
\text { de correção ou disciplina. }\end{array}$ \\
\hline 146 & Constrangimento ilegal & $\begin{array}{l}\text { Constranger alguém, mediante violência ou grave } \\
\text { ameaça, ou depois de lhe haver reduzido, por } \\
\text { qualquer outro meio, a capacidade de resistência, a } \\
\text { não fazer o que a lei permite, ou a fazer o que ela } \\
\text { não manda. }\end{array}$ \\
\hline 147 & Ameaça & $\begin{array}{l}\text { Ameaçar alguém, por palavra, escrito ou gesto, ou } \\
\text { qualquer outro meio simbólico, de causar-lhe mal } \\
\text { injusto e grave. }\end{array}$ \\
\hline 148 & Seqüestro e cárcere privado & $\begin{array}{l}\text { Privar alguém de sua liberdade, mediante seqüestro } \\
\text { ou cárcere privado. }\end{array}$ \\
\hline 149 & $\begin{array}{l}\text { Redução a condição análoga à } \\
\text { de escravo }\end{array}$ & $\begin{array}{l}\text { Reduzir alguém a condição análoga à de escravo, } \\
\text { quer submetendo-o a trabalhos forçados ou a } \\
\text { jornada exaustiva, quer sujeitando-o a condições } \\
\text { degradantes de trabalho, quer restringindo, por } \\
\text { qualquer meio, sua locomoção em razão de dívida } \\
\text { contraída com o empregador ou preposto. }\end{array}$ \\
\hline
\end{tabular}

Sobre a população usuária do Setor de Psicologia teríamos a seguinte leitura a partir da tipificação da queixa: 49\% de casos relativos ao Artigo 129; 37\% de casos relativos ao Artigo 147; 6\% de casos relativos ao Artigo 136; 4\% de casos relativos ao Artigo 146; e 3\% de casos relativos aos outros Artigos. No capítulo sobre estatísticas algumas informações sobre esta temática são apresentadas pormenorizadamente. Durante os atendimentos era comum o relato de outros fatos que poderiam ser tipificados como crimes, alguns se encontravam em andamento na Justiça enquanto outros não haviam sido reportados às autoridades competentes. 


\section{Estágio e Voluntariado}

O projeto-piloto do Setor de Psicologia do JECRIFAM ofereceu estágio e contou com mão-de-obra voluntária durante sua existência. Um programa de estágio se presta à função de extensão universitária, possibilitando aos estudantes experiências práticas no campo de trabalho profissional. Por este motivo o estágio sempre esteve vinculado a disciplinas curriculares das instituições de ensino que firmaram contrato com o Tribunal de Justiça. Em nenhum momento o programa de estágio serviu para cobrir a falta de mais profissionais no Setor de Psicologia, o que pode ser confirmado pelas estatísticas de atendimento que apresentam médias similares de atendimentos mensais com ou sem o estágio.

Desde abril de 2004 foi realizado o programa de estágio para alunos de $5^{\circ}$ ano de cursos de graduação em Psicologia. Neste ano foram contratados quatro estagiários, dois junto ao Instituto de Psicologia da Universidade de São Paulo, USP, e dois junto à Faculdade de Psicologia da Pontifícia Universidade Católica, PUC-SP. No ano de 2005 foram contratados cinco estagiários, sendo quatro da PUC-SP e um da Faculdade de Psicologia da Universidade Presbiteriana Mackenzie e, em 2006, outros quatro estagiários, todos da PUC-SP. No período compreendido entre setembro de 2005 e junho de 2006 contamos também com a colaboração de um psicólogo voluntário.

O programa de estágio era anual e requeria quinze horas semanais de presença no Juizado. O psicólogo voluntário se adequou ao modelo do estágio, participando das atividades juntamente com os estagiários, o que não impediu de recaírem sobre ele maiores responsabilidades e cobranças.

A intenção foi realizar uma transmissão de um saber-fazer clínico em instituição a partir da circulação e experiência neste determinado contexto, ou seja, um aprendizado direto, 
mais próximo dos moldes de uma aprendizagem artesã, experiencial. Além desta aprendizagem presencial, contava-se com dispositivos semanais de estudo, elaboração, responsabilização e capacitação: supervisão institucional, supervisão de casos, reunião e grupo de estudos. Os estagiários também recebiam indicações de leituras pertinentes às questões suscitadas nos casos que acompanhavam. No início havia algo da ordem de uma apresentação e capacitação para os dispositivos, suas burocracias, papeladas, relações com os outros setores do Juizado etc.

A participação nos atendimentos contava com quatro momentos diferentes:

$1^{\circ}$ - leitura e discussão de prontuários de casos já encerrados;

$2^{\circ}$ - Entrada como observador em caso novo, acompanhando o psicólogo;

$3^{\text {o }}$ - Entrada participativa junto com o psicólogo;

$4^{\mathrm{o}}$ - Realização de atendimento acompanhado de outro estagiário ou sozinho.

A passagem de um momento a outro dependia da avaliação conjunta do psicólogo e de cada estagiário, chegando até a ser pauta da supervisão institucional.

A presença dos estagiários possibilitou, também, que muito da produção discursiva dos atendimentos fosse anotada, principalmente no momento em que entravam como observadores, quando era possível uma transcrição de diversas falas. No capítulo sobre atendimentos este material, que é apresentado com os devidos cuidados já citados, enriquece em muito a discussão.

A realização de anotações durante os atendimentos se sustentava no fato deste ser um projeto-piloto, que portanto priorizava a coleta de informações sobre o campo. Muitos cidadãos também citavam a anotação, mas, ao contrário do que ocorre em outros contextos, pediam que determinadas falas fossem anotadas. Este fato se deve certamente, entre outras coisas, ao contexto da Justiça. 
A anotação durante uma sessão pode, no entanto, suscitar questões acerca das dificuldades em se realizar uma escuta flutuante e anotar ao mesmo tempo. Realmente, em atendimentos com um só profissional geralmente muito pouca coisa pode ser anotada, mas após o atendimento é possível complementar tais anotações com suas impressões e lembranças.

Por tudo isso parece justa a apresentação de estagiários e voluntário por seu esforço e rica contribuição para o Setor de Psicologia e também para esta dissertação:

Turma de 2004:

Daniella R. Valverde de Almeida, Lígia Polistchuck, Roberta Brandi Ferreira e Vanessa Abdo França.

Turma de 2005:

Ana Carolina H. F. de Campos, Daniela Fuchs, Kláucia do Prado Molan, Thaïs Albernaz Guimarães, Vanessa Cristina B. Alves.

Turma de 2006:

Cristina Pinheiro Costas, Liliane Tomi Motooka, Maíra Kazue Ogawa, Mariana Fancio Gonçalo e Patrícia Dancieri Martinelli.

Voluntário:

Francisco Meirelles de Azevedo Pimentel. 


\section{Algumas referências do serviço implementado}

Quando da fundação do Setor de Psicologia havia a preocupação de como iria operar o serviço de atendimento psicológico para os usuários do Juizado. Afinal o projeto previa que a referência dos atendimentos seria a Psicanálise sem, no entanto, esclarecer como tal referência iria funcionar. Apenas com a prática de atendimentos foi possível construir um campo de pertinências e limites da operacionalização desta referência psicanalítica.

A opção pela notação psicólogo-psicanalista deve-se à consideração de que a presença deste profissional era legitimada por dois vieses que se atualizavam quando de suas realizações: o ator institucional, agente do Estado, realizava seu trabalho a partir do lugar de psicólogo contratado, no mesmo tempo em que um psicanalista operava a partir de uma ética sustentada em seu desejo. Porém se faz necessária uma separação teórica deste lugar condensado, de forma que quando for usada apenas a palavra psicólogo temos como referência este primeiro lugar, enquanto que a aparição de psicanalista aponta para a realização da estrita prática da psicanálise.

Este capítulo apresenta, então, algumas contribuições da Psicanálise que operaram como referência da atuação do psicólogo-psicanalista no começo do trabalho na instituição. Além disso, são apresentadas algumas referências do funcionamento do Fórum Criminal, fundamentadas na legislação vigente, que possibilitam uma leitura sobre os limites institucionais, de forma a melhor situar o leitor acerca do contexto.

Esta apresentação possibilita uma primeira leitura sobre as particularidades de uma escuta psicanalítica cabível a este contexto, o que permite retomar a questão-guia: qual escuta cabe oferecer neste contexto? 
A apresentação das referências psicanalíticas para os trabalhos dentro de um Fórum Criminal pode ser enriquecida por um percurso acerca de alguns pontos fundamentais, que serão aqui apresentados ora em forma de questões ora como afirmativas, sobre a psicanálise e este específico contexto.

A primeira afirmação a se considerar recai sobre as particularidades de um serviço de atendimento proposto no contexto da Justiça que tem algumas diferenças em relação à clínica psicanalítica assim como foi proposta originalmente por Freud. Não se faria possível transpor o método psicanalítico (aos moldes de uma análise tradicional de consultório) diretamente para dentro de uma instituição sem considerar as especificidades e limitações impostas pelo contexto, principalmente porque tal instituição não tem uma meta clínica, analítica ou terapêutica. Ficou, desde o início, claro que uma sala, um analista e um analisante (talvez até um divã, quem sabe?), não seriam suficientes para dar suporte à realização de análises dentro do Fórum Criminal. Além disso, quem procuraria fazer sua análise em um Fórum Criminal? ${ }^{1}$

Havia assim, de saída, o trabalho de enfrentamento das dificuldades inerentes à tentativa de encontrar pertinência a uma ética de tratamento psicológico historicamente consolidada $^{2}$ e uma instituição de realização de Justiça. Não será feito aqui um cálculo sobre possíveis efeitos analíticos ou terapêuticos frutos da realização de Justiça, o que até parece ser possível mas não é a intenção da presente dissertação. Antes, parece importante identificar as limitações impostas pelos objetivos institucionais, sua missão, assim como o lugar que ocupa tal instituição no tecido social. Afinal, o que caberia desta ética neste contexto? E o que implica a presença desta ética dentro deste contexto?

\footnotetext{
${ }^{1}$ Esta questão, que neste ponto pode parecer soar como uma piada, apresenta-se como fundamental para o entendimento do trabalho com as demandas. A discussão encontra-se nas considerações sobre os atendimentos. ${ }^{2}$ A psicanálise é uma prática ética, que opera num plano muito particular, ou seja, cada análise terá um proceder muito próprio, não se constituindo como uma técnica universal que possa ser aplicada a qualquer um em qualquer situação. Para um maior aprofundamento ver O Seminário, Livro 7 - A Ética da Psicanálise (LACAN, 1998).
} 
Como mencionado anteriormente, a missão da instituição judiciária é a realização da Justiça, ou seja, realizar legitimamente os ritos judiciários, garantindo os direitos e a responsabilização a quem de direito. A Justiça tem por missão portanto julgar e determinar, de forma a garantir a matéria constitucional e as outras Leis vigentes. A Justiça Criminal, especificamente, tem como particularidade geralmente se realizar quando de queixas de violação dos chamados direitos individuais (à vida, à liberdade, à segurança, à propriedade privada etc). Esta individualização de direitos e responsabilidades e suas implicações nos casos de crimes de família parecem merecer algumas reflexões e cuidados, que são apresentados à frente (pg. 121).

Não seria possível também deixarmos de considerar o fato de que a Justiça é uma referência do tecido social. Porém, tal consideração implica em uma atenção para os efeitos que tal função de referência faz incidir sobre as possibilidades de oferecimento de uma escuta. Parece necessária a atenção para que esta escuta não possa incidir de maneira a esvaziar o sentido da realização de Justiça, nem tampouco concorrer ou substituí-lo. Parece importante lembrar que um sujeito pode ficar fortemente vinculado a um analista em determinado momento de um trabalho. Neste contexto há que atentar para que tal vinculação não opere na contramão da realização de Justiça e do exercício de cidadania possível dentro da Justiça Criminal.

Podemos, assim, desdobrar nossa questão-guia em outras questões. A partir destas reflexões acima temos, portanto, uma primeira questão: que escuta pode realizar um analista neste contexto?

Além dos limites que o objetivo da instituição implica, há que considerar também quais condições devem ser resguardadas a fim de viabilizar um trabalho de escuta referido à ética da psicanálise neste contexto. Tais condições também estão sujeitas à limitação da

\footnotetext{
${ }^{3}$ Aqui remeto ao desenvolvimento de questão análoga em outro contexto: no trabalho O que pode um analista no Hospital (MORETTO, 1996).
} 
pertinência, ou seja, devem ser cabíveis a tal contexto. Podemos formular, assim, outra questão: quais condições, em sendo cabiveis, devem ser observadas para o oferecimento de escuta dentro desse contexto?

Um caminho possível para abordarmos estas questões pode partir de um aprofundamento sobre uma das principais referências para a Justiça Criminal: aquela que articula a noção de cidadão a um contexto de democracia de direitos.

Como é de conhecimento comum, a noção de cidadão teve sua origem na Grécia. Segundo Silva ${ }^{4}$, com "o advento da democracia (...) o poder político saiu das mãos dos reis e passou para a assembléia dos cidadãos", tal cidadania baseada nas noções de isonomia e liberdade, sendo o cidadão um "partícipe do poder" político. Por isonomia podemos entender que o exercício de cidadania não teria como "requisito qualquer conhecimento teórico ou técnico", ou seja, não se supunham "habilidades ou capacidades especiais". O requisito de que se tratava, para o exercício da política, era "a condição de homem livre".

Sobre a liberdade, neste contexto grego, se faz necessário entender uma diferenciação, comum à época, entre liberdade e necessidade. Homem livre era aquele que não se encontrava subordinado à necessidade de trabalhar para sobreviver, isso porque "supunha-se que a deliberação acerca do bem da cidade excluía a defesa de interesses próprios ao reino da necessidade" (ou dos seus) não se encontrariam em condições de se posicionar em prol do bem comum. As funções políticas ficavam, desta forma, a cargo de uma elite de proprietários e comerciantes, os cidadãos portanto. Além de àqueles que trabalhavam, estava vedada a participação a mulheres, crianças, jovens, estrangeiros e escravos.

\footnotetext{
${ }^{4}$ SILVA, L.S. - Felicidade, 2007.

${ }^{5}$ Id., ibid.
} 
Ainda segundo Silva ${ }^{6}$, o advento da democracia (e da cidadania) marcou uma passagem das noções de organização humana (sociedade) e da própria condição humana. De uma organização que destacava o valor individual, a singularidade, exemplificada na imagem do herói (período homérico), passou-se para formações solidárias, nas quais "o desempenho de cada um está vinculado ao de todos os outros". Porém tal passagem não significou o desaparecimento do indivíduo, o autor propõe que "este [indivíduo] e a cidade devem ser concebidos em termos de uma vinculação orgânica, de modo que um seja impensável sem a outra". Afirma, ainda, que "é nesse vínculo orgânico que repousa a virtude do cidadão, portanto a justiça na cidade e a felicidade comum" e que esta passagem modificou a condição humana, de forma ao "indivíduo somente se realiza[r] como tal numa cidade justa, razão pela qual política e justiça [passaram a estar] intimamente associadas”.

A partir destas considerações se faz possível sustentar o entendimento de que haveria uma articulação necessária, uma co-determinação, entre cidadania e Justiça, que operaria como alicerce fundamental já na democracia da Grécia antiga.

A noção de cidadão se transformou ao longo dos séculos. De um partícipe direto das decisões e do poder político da cidade-estado, encontramos hoje em dia uma cidadania fundamentada na noção de representatividade política. Através do voto, cabe ao cidadão escolher seus representantes nos debates e decisões estatais ${ }^{7}$.

Uma retomada dos cinco fundamentos da República Federativa do Brasil (Artigo $1^{\circ}$ da Constituição Federal da República) permite uma compreensão da dimensão que a noção de cidadania possui atualmente, são eles: "soberania, cidadania, dignidade da pessoa humana,

\footnotetext{
${ }^{6}$ Id., ibid.

${ }^{7}$ Os dados disponíveis atualmente apresentam grande preponderância de normas jurídicas vigentes propostas pelos representantes eleitos. Em artigo recém publicado no jornal Folha de São Paulo (06 de janeiro de 2008), Larissa Guimarães, apresentou as estatísticas oficiais da produção de Leis de origem popular, ou seja, de Leis propostas por cidadãos ao Congresso. Afirma, neste artigo, que desde a entrada em vigor da Constituição Federal em 1988 já foram aprovadas quatro (4) Leis a partir de propostas de origem popular no Brasil, o que corresponde a $0,05 \%$ das " 9.429 proposições que se tornaram norma jurídica no período".
} 
valores sociais do trabalho e da livre iniciativa e pluralismo político". Temos portanto a cidadania como um dos alicerces fundamentais da República.

Atualmente a noção vigente de cidadão também se alargou e em nosso país abarca a todos os brasileiros. Segundo a Constituição, em seu Artigo $5^{\circ}$,

Todos são iguais perante a lei, sem distinção de qualquer natureza, garantindo-se aos brasileiros e aos estrangeiros residentes no País a inviolabilidade do direito à vida, à liberdade, à igualdade, à segurança e à propriedade.

Temos, portanto, estes valores como fundamentos da cidadania. Ainda segundo a Constituição, em seu Capítulo III, Artigo 12. ${ }^{\circ}$, são considerados cidadãos brasileiros:

I - natos:

a) os nascidos na República Federativa do Brasil, ainda que de pais estrangeiros, desde que estes não estejam a serviço de seu país;

b) os nascidos no estrangeiro, de pai brasileiro ou mãe brasileira, desde que qualquer deles esteja a serviço da República Federativa do Brasil;

c) os nascidos no estrangeiro de pai brasileiro ou de mãe brasileira, desde que sejam registrados em repartição brasileira competente ou venham a residir na República Federativa do Brasil e optem, em qualquer tempo, depois de atingida a maioridade, pela nacionalidade brasileira;

II - naturalizados:

a) os que, na forma da lei, adquiram a nacionalidade brasileira, exigidas aos originários de países de língua portuguesa apenas residência por um ano ininterrupto e idoneidade moral;

b) os estrangeiros de qualquer nacionalidade, residentes na República Federativa do Brasil há mais de quinze anos ininterruptos e sem condenação penal, desde que requeiram a nacionalidade brasileira.

$\S 1^{\circ}$ Aos portugueses com residência permanente no País, se houver reciprocidade em favor de brasileiros, serão atribuidos os direitos inerentes ao brasileiro, salvo os casos previstos nesta Constituição.

$\S 2^{\circ}$ - A lei não poderá estabelecer distinção entre brasileiros natos $e$ naturalizados, salvo nos casos previstos nesta Constituição.

Vemos, assim, uma definição de cidadania bastante abrangente. Não parece, no entanto, relevante para este momento do texto um aprofundamento nas regras de exceção que definem diferenças de responsabilidades no exercício de cidadania (idade, alfabetização, militares, agentes do Estado etc).

A leitura da Constituição também revela como vigente a premissa que articula cidadania e Justiça, instituição que neste texto evidentemente figura como arena privilegiada 
do exercício de cidadania. Assumiremos aqui a posição de que tal articulação também é condição à nossa sociedade, uma vez que o presente trabalho se pretende condizente com nossa Constituição e outras Leis em vigência, posto que estas referências legais indicam claramente o Tribunal de Justiça como uma das arenas do exercício da cidadania.

A Justiça, vale lembrar, julga a fim de determinar: a garantia dos direitos dos cidadãos e instituições e a responsabilização dos cidadãos e das instituições, ou seja, as garantias da cidadania. Na Justiça o cidadão é responsabilizado por seus atos no sentido de cumprir as determinações da lei escrita que, além de direitos, regra deveres. Uma das referências do trabalho do Setor de Psicologia do JECRIFAM deveria ser, portanto, fomentar o exercício de cidadania quando do percurso destes sujeitos-cidadãos na instituição judiciária. A questão que emergia era: como o oferecimento de escuta clínica poderia ajudar no exercício de cidadania?

A Constituição deve ser o contrato fundamental de uma sociedade que tem por referência um Estado Democrático de Direitos. Porém, como é de conhecimento comum, nem todos os princípios, direitos e responsabilidades definidos pela Constituição Federal do Brasil vêm sendo garantidos, seja pelo Estado seja pela sociedade (cidadãos, agrupamentos e instituições não-estatais). Desde a época de sua entrada em vigor em 1988, muitos avanços já ocorreram nesse sentido, porém as lacunas são facilmente identificáveis. Apesar dos esforços de uma parcela de população e do Estado, parece que uma função da Constituição, a de norteador ideal das relações sociais, tem sido de difícil implementação, aplicação e manutenção. Diariamente vemos uma série de direitos e deveres serem desrespeitados, por agentes do Estado e particulares.

No âmbito judiciário, portanto, o trabalho dos operadores do Direito é atravessado pela noção de responsabilização legal, seja cível ou criminal. Esta responsabilização incide sobre o conjunto de comportamentos, posicionamentos e realizações concretas de determinado cidadão no que tais atos podem ser pertinentemente associados a contratos ou a alguma 
determinação judicial, que vale lembrar, tem força de Lei. A responsabilização legal dá-se quando a determinado cidadão é imputado algum dever, pena, restrição etc.

A responsabilização também é questão de suma importância para o trabalho de um psicanalista. A realização de atendimentos pautados na ética da psicanálise também promove um movimento de responsabilização. Porém, a escuta de um analista tem por referência outros parâmetros de responsabilização.

A Psicanálise, a partir de Freud, sustenta um modelo de homem não totalmente senhor de si. A partir de seu trabalho como clínico, Freud, percebeu que seus pacientes portavam um grande desconhecimento acerca de seu próprio funcionamento psíquico e suas identidades, o que acarretava que decisões e posicionamentos comportassem sempre algo de uma profunda alienação acerca de suas motivações, que operavam como tendências inconscientes. Assim, uma parte de toda conduta humana parecia psíquica e socialmente descentrada, errática ou desordenada.

Freud, em Sobre os sonhos (1910), propôs que o trabalho de uma análise implicasse em um movimento de responsabilização por estas tendências inconscientes, ali onde tais tendências se realizavam através de escolhas. Neste texto aludiu a um momento comumente considerado de total inconsciência, o sono, para propor que até o despertar, ou o não despertar, de determinado sono estivesse sempre articulado a uma escolha à qual caberia responsabilização.

Pelo menos, devemos supor que, mesmo durante o sono profundo, um certo quantum de atenção livre monta guarda contra os estímulos sensoriais e que esse guarda pode considerar às vezes mais aconselhável o despertar do que a continuação do sonho. De outra maneira, não se explicaria que possamos ser acordados a qualquer momento por estímulos sensoriais de certa qualidade. (FREUD, Sobre os Sonhos, pg. 40)

Freud, neste mesmo texto, ofereceu diversos exemplos de como o despertar e o manter-se dormindo seriam escolhas e que, mesmo em sendo inconscientes, haveria 
responsabilidade sobre este posicionamento, ou seja, qualquer que seja a ação/posição assumida por quem está dormindo implicaria em efeitos/respostas psíquicas.

A escuta de um analista tem por referência a fala de seu paciente. Opera, por esta forma, escutando essas construções discursivas como fruto de diversas escolhas, algumas conscientes, outras inconscientes. A posição de um analista frente à fala, portanto, será sempre supor alguma implicação do sujeito falante a suas escolhas inconscientes, o que no percurso de uma análise provoca o analisante a se assenhorar de seus atos e motivações, no que implicam, no sentido da realização, as tendências inconscientes.

Um fundamento ético da psicanálise se articula a este movimento de responsabilização: tais "leituras" desse inconsciente são operação possível só-depois. Apenas após um determinada fala faz-se possível construir um sentido para as manifestações do inconsciente. Em uma análise, portanto, este movimento de se assenhorear, dessa responsabilização como construção de sentido, se dará em um tempo a posteriori.

Freud percebeu também que as questões relativas à constituição de cada sujeito iriam incidir de forma determinante sobre suas escolhas, seus sintomas e visões-de-mundo, atualizando as particularidades de tal constituição, e que tal operação era correlata de um profundo desconhecimento destes mesmos sujeitos acerca da própria constituição, que permanecia inconsciente. Desta forma todo o espectro de condutas humanas pareceu-lhe remetido a uma organização psíquica que operava prioritariamente remetida ao inconsciente. Propôs que a referência para a realização das tendências inconscientes deste aparelho psíquico seria um desejo inconsciente irredutível à satisfação.

A partir desta visão psicanalítica temos que o próprio movimento civilizatório produz homens que, ao se conduzir dentro desta civilização, invariavelmente realizam uma série de desencontros (num âmbito psíquico e/ou social) vividos como angústia e sofrimento, cuja negação pode se realizar em uma série de contradições, violências e alienações. 
A psicanálise propõe desde Freud, então, alguns modelos conceituais que ajudam psicanalistas (e outros clínicos) a dirigirem os tratamentos dessas pessoas. Conceitos como inconsciente. Este conceito possibilita, em uma primeira aproximação, a leitura de uma condição humana na qual o homem não é completamente senhor, no sentido da decisão consciente, dos seus atos. Em seu uso clínico, permite circunscrever: algo da multiplicidade de motivadores de cada decisão; o compromisso entre diversas forças ou tendências inconscientes que buscam satisfação; o conjunto de realizações e efeitos condensados resultantes de cada ação; e, ainda, o conjunto de materiais recalcados, ou seja reprimidos da consciência.

Inconsciente é, muito provavelmente, o mais importante conceito psicanalítico. Sua definição, no entanto, pode parecer difícil, uma vez que em diferentes contextos, inconsciente pode se prestar a diferentes usos. A escuta de um psicanalista estará sempre atenta ao inconsciente, no que as manifestações do inconsciente desvelam algo de desconhecido de e para aquele que fala.

As contribuições de Jacques Lacan sobre o tópico do inconsciente agregam precisão às proposições freudianas. Podemos retomar a passagem, da Introdução à edição alemã de um primeiro volume dos Escritos, em Outros Escritos (2003), na qual Lacan propôs que:

E, no entanto, o recurso é o inconsciente, a descoberta de Freud de que o inconsciente trabalha sem pensar, nem calcular, nem tampouco julgar, e que, ainda assim, o fruto está aí: um saber que se trata apenas de decifrar, já que ele consiste num ciframento. (LACAN, Outros Escritos, pg. 553)

Junto aos analistas, inconsciente aparece como um significante privilegiado da condução do trabalho psicanalítico, dada sua irredutibilidade completa à consciência. Mesmo o fim de uma análise não esgota o inconsciente. O fim de uma análise marca o fim do trabalho sobre as formações relativas às questões e dramas do sujeito, no que isso foi possível sob transferência. Esse limite da transferência é ponto que marca a passagem: de uma posição na qual se depende do trabalho de um psicanalista para se responsabilizar por tais formações a 
um se assenhorear do que concerne a suas questões e dramas. Tal passagem não determina o fim deste tipo de formações, posto que o sujeito continua sendo continuamente afetado em seu percurso de vida, o que implica na construção de novas formações inconscientes. Marca antes o fim de um trabalho possível com aquele psicanalista, geralmente pelo atravessamento da fantasia que sustentava essa transferência.

Numa abordagem lacaniana, temos alguns conceitos fundamentais que oferecem algum oriente para a escuta clínica. O conceito de Outro como campo da linguagem, inconsciente, foi ponto de partida (desde os primeiros seminários de Lacan) para o trabalho com esse sujeito efeito de linguagem ao qual faz escuta um psicanalista. A partir desta consideração que o desejo do homem é o desejo do Outro, Lacan propôs que "o sujeito se manifesta em sua hiância, ou seja, naquilo que causa seu desejo" (Mais, Ainda, pg. 20).

Esta questão, segundo Zizek em Eles Não Sabem o Que Fazem (1992), é suportada como expressão de um hiato que resta da articulação entre identificação simbólica, I( $a$ ) (que se refere ao Ideal-do-eu), e identificação imaginária, i(a) (que se refere ao eu-ideal), e que pode ser traduzida da seguinte forma "você me diz isso, mas que está querendo me dizer com isso, através disso?". Zizek comenta que tal articulação “sob o domínio da identificação simbólica, constitui o mecanismo pelo qual o sujeito é integrado num dado campo sóciosimbólico", a partir do encadeamento dos diferentes lugares ocupados, o que nos interessa diretamente pela perspectiva política. Diz Zizek:

Depois de cada basteamento da cadeia significante, que fixa retroativamente seu sentido, resta sempre um certo hiato, uma abertura que se expressa, na terceira forma do grafo, pela famosa pergunta 'Che vuoi?' - 'Você está me dizendo isso, mas que quer fazer, onde quer chegar?'(pg. 109)

Essa pergunta-sinal, que se coloca acima da curva do basteamento, indica, assim, a insistência de um abismo entre o enunciado e sua enunciação: no nivel do enunciado você me diz isso, mas que está querendo dizer com isso, através disso? (pg. 110)

E é exatamente na posição dessa pergunta, que surge acima do enunciado, no lugar do 'Porque você está me dizendo isso?', que devemos situar o desejo (...) em sua diferença da demanda. (pg. 110) 
Este Outro foi abordado num segundo momento também numa perspectiva corporal. O gozo do corpo do Outro é operação apontada por Lacan como tentativa de interrupção da fórmula do ser sexuado, por apontar a infinitude, o interesse de a partir de dois fazer um. $\mathrm{O}$ amor seria a manifestação desse desejo de ser um.

Um sujeito situado a partir de desejo e gozo é referência para a escuta de um psicanalista em uma abordagem lacaniana. Em seu seminário Mais, Ainda, Lacan propõe que o gozo seja uma forma de satisfação "que não serve pra nada" (pg. 11), no sentido de não ser útil. Neste mesmo livro, sustenta que o amor é "signo de uma troca de discurso" (pg. 27), posto que o amor "se baseia numa certa relação entre dois saberes inconscientes" (pg. 197), sendo uma resposta que nega a impossibilidade, real, de inscrição da relação sexual no dizer: "não há, dentro do dizer, existência da relação sexual” (pg. 198). A partir disso definiu a relação sexual "como aquilo que não pára de não se escrever" (pg. 198), cuja negação pela via do reconhecimento opera a ilusão de substituir essa impossibilidade por um "pára de não se escrever", tendendo a um "não parar de se escrever" que vai produzindo mais inconsciente ainda.

A proposta de Lacan parece condizente com as considerações de Freud em $\mathrm{O}$ MalEstar da Civilização, na qual afirmou que seríamos mais felizes se abdicássemos de vez dessa vida social repleta de cerceamentos e leis de convívio e voltássemos a buscar satisfação nas formas mais primitivas de relacionamento. Mas se neste contexto de Justiça, ou seja em um lugar onde se operam legitimamente restrições à satisfação pulsional, a busca pela felicidade se apresenta como incabível, o que buscam os cidadãos usuários desta instituição?

A fim de maior precisão, temos o discurso do analista como uma suposição: suponho que há mais no que você disse do que esperava ser reconhecido por mim, ou seja, para além dessa negação - a operação de um saber-fazer inconsciente com alíngua e toda sorte de produções/produtos que se atualizam nesse dito, nesse ato - atesta aí um real. O que implica 
que o psicanalista opere pelo rechaço do que lhe é demandado via amor de transferência, ou seja, não reconhece nem legitima essa negação do real, faz-lhe escuta, provoca o analisante a falar desta transferência.

Neste ponto há também outra interessante contribuição de Lacan na sua Introdução à edição alemã de um primeiro volume dos Escritos, em Outros Escritos (2005), que já aponta para a direção de transmissão de um real, que se atualiza pela insistência desse abismo, e para o qual aponta a intervenção do analista:

É por escapar (no sentido do tonel) que um discurso adquire seu sentido, ou seja, pelo fato de seus efeitos serem impossiveis de calcular. (Pg. 550)

É disso que resulta só haver comunicação na análise por uma via que transcende o sentido, aquela que provém da suposição de um sujeito no saber inconsciente, ou seja, no ciframento. (Pg. 555)

Lacan, neste mesmo texto, transmite uma forma de apreensão deste real a partir de sua articulação com o discurso:

Como não considerar que a contingência, ou o que cessa de não se escrever, não seja o lugar por onde se demonstra a impossibilidade, ou o que não cessa de não se escrever? E que por aí se ateste um real que, apesar de não ser mais bem fundado, seja transmissível pela escapada a que corresponde todo discurso. (Pg. 556)

O psicanalista, portanto, não pode sustentar uma posição inocente nestes diversos encontros (com cidadãos e outros atores institucionais), antes parece cabível assumir a responsabilidade afirmativa de que em tais encontros uma realização puramente pragmática (cidadania sem subjetividade) é algo que não se sustenta, posto que necessariamente os sujeitos-cidadãos envolvidos estão psiquicamente implicados com seus ditos, posições e escolhas. Para um psicanalista, um encontro neste contexto nunca é sem efeito sobre o psiquismo daqueles que se oferecem como presença. Mas a responsabilização por este "se oferecer como presença" não parece das mais fáceis.

As produções negativas desse real acabam por gerar uma série de desencontros nos mais diversos âmbitos institucionais, principalmente nos encontros entre atores institucionais 
e cidadãos. É aí que o pragmatismo operacional da instituição parece fazer função: cala os sujeitos usuários em nome da sustentação do sentido da realização de Justiça. Se a realização de Justiça depende deste silenciamento subjetivo dos sujeitos envolvidos, no que (ou como) tais sujeitos poderão, posteriormente, se responsabilizar por tal realização?

Aqui, claramente há uma opção de leitura institucional na qual o rito judiciário é entendido como encontro no qual todos os presentes tem participação e responsabilidades, o que implica que somente a realização das funções dos atores institucionais não garantiria a realização de uma Justiça cidadã, ou seja, uma Justiça na qual o cidadão seja contemplado com uma experiência participativa, de realização de justiça.

Retomando, assim, o contexto da Justiça, entretanto, temos ainda que inconsciente neste contexto de Justiça infelizmente remete diretamente à possibilidade de interdição civil, ou seja, tal significante já vem de história prévia na instituição, e justamente com a função de apagamento da cidadania. Por conta do risco da realização do ato de interdição, que legalmente cabe à instituição judiciária, é imprescindível muita atenção ao uso do significante inconsciente no dia-a-dia do trabalho. No entanto seria impossível uma contribuição da Psicanálise que pudesse prescindir do uso da noção de inconsciente.

Disso, temos que a circulação do discurso psicanalítico na instituição também deve ser matéria de atenção do clínico.

Estas limitações que implicam um trabalho em instituição, que podem se afigurar primeiramente como diferenças são de suma importância para a direção e condução dos trabalhos. A fim de melhor situar o leitor acerca destes limites, direção e condução os capítulos subseqüentes apresentam o modelo de serviço implementado a partir do relato de casos atendidos. Outras contribuições da Psicanálise ao modelo de atendimento psicológico do Setor de Psicologia serão apresentadas e discutidas a partir dos casos. 
A escolha pela apresentação de casos clínicos tem como propósito possibilitar a transmissão de aspectos clínicos que escapariam de uma apreciação puramente teórica. Há, portanto, a aposta no relato de experiências como via de transmissão. O trabalho de um clínico tem por referência os discursos realizados nas sessões e não possíveis dados da realidade comunicados pelos usuários. A particularidade de cada caso também aponta para a limitação da apresentação de um recorte puramente teórico, que geralmente só pode se situar a partir de modelos genéricos ou ideais de homem. Temos disso algumas limitações e potencialidades que incidem tanto na questão da transmissão quanto no entendimento das situações clínicas.

Atentar à produção discursiva remete à possibilidade de apreensão não de uma realidade, mas de algo de uma verdade clínica desses sujeitos. Tal referência possibilita, no entanto, apenas a apreensão de uma meia-verdade, aquela possível pelo meio da linguagem. Como nos propõe Dominique Fingermann, “... não há mais o que esperar das palavras do outro: a palavra é o pior, mas não existe nenhum outro jeito, há que continuar, pois o silêncio é o pior". 


\section{Condições gerais de trabalho e supervisão}

Uma ampliação das conversas com o CRAVI foi pedida persistentemente pelo psicólogo junto à coordenação desta instituição. Além disso, algumas melhorias das condições de trabalho também foram insistentemente frisadas, entre outras: salário, materiais para a realização dos atendimentos, computador, supervisão, mais técnicos etc. Em março de 2004 a primeira resposta: um computador, sem impressora. Até então o trabalho fora realizado apenas com um caderno, papel sulfite, canetas e lápis, além de uma prancheta, trazida pelo próprio psicólogo. A coordenação do Juizado, ao tomar conhecimento da situação, emprestou uma impressora matricial que não estava sendo usada.

Em abril de 2005, então, a coordenação do CRAVI acatou os reiterados pedidos e decidiu contratar uma supervisão. Uma psicóloga da própria ONG parceira (Instituto Therapon Adolescência) foi escolhida pela coordenação do CRAVI para dar supervisão no Setor de Psicologia do JECRIFAM. O modelo oferecido era nomeado como supervisão institucional de equipe. Na prática a equipe era composta por apenas uma pessoa, mas o trabalho foi desenvolvido em reuniões semanais nas quais participavam também os estagiários e o psicólogo voluntário. O modo de funcionamento deste dispositivo teve algumas alterações com o tempo. A supervisão operou como espaço privilegiado de elaboração das difíceis temáticas que emergiam nos atendimentos, além de facilitar a comunicação dessa soma de "equipe" e estagiários. Os principais temas discutidos eram: dificuldades nos atendimentos, relações entre estagiários, relações dos estagiários com o psicólogo e algumas dificuldades na realização do grupo de estudos.

Aos poucos as condições de trabalho foram melhorando, aparentemente também porque as repercussões do trabalho causavam algum efeito: tanto o Juizado ofereceu mais salas quanto o CRAVI passou a "conseguir" com menos demora os materiais pedidos. 


\section{PARTE II}

RELATOS DO PERCURSO DENTRO DO FÓRUM 


\section{O modelo de serviço implementado}

Neste capítulo é apresentado o modelo do serviço de atendimento do Setor de Psicologia do JECRIFAM. Para subsidiar as discussões abaixo apresentadas, além da experiência pessoal do pesquisador no campo, o principal material pesquisado foi o conjunto de pastas de prontuários de casos do Setor de Psicologia.

Tais pastas eram compostas de: transcrições e/ou anotações dos atendimentos, o prontuário do caso (que era subdividido em diversos itens), relatório de conclusão, declaração, formulário do telefonema de verificação de risco de vida, matérias gráficos produzidos pelos usuários (em casos de atendimentos a criança e/ou adolescente), cópia do Termo Circunstanciado de Ocorrência e do encaminhamento para o serviço (presente em aproximadamente metade dos prontuários), e outras papeladas (cópias de laudos de outros profissionais anexados no processo, anotações de supervisão, materiais trazidos pelos usuários, anotações de contatos telefônicos etc).

Para a pesquisa foram lidas aproximadamente 600 pastas que têm uma média de 10 a 30 páginas. Após uma primeira triagem foram escolhidos 25 casos, estudados mais profundamente para, só então, escolher entre estes os casos que seriam realmente usados no corpo do texto. Além disso algumas frases destas pastas (mesmo das que não foram escolhidas) foram anotadas e aparecem no correr das discussões.

Os critérios para a escolha dos casos foram: riqueza e clareza das anotações, capacidade de ilustrar uma situação corriqueira, apresentação de assuntos que parecem ter maior relevância para a pesquisa e possibilidade de supressão de dados sem muita perda de sentido (este último critério foi usado apenas após a primeira triagem).

$\mathrm{Na}$ apresentação dos casos optou-se, também, pela supressão dos dados mais horríveis por uma opção política, estética e ética. No entanto, apesar dos esforços neste sentido, algo do 
horror aparece nos casos apresentados, pois excluí-lo completamente seria esvaziar por demais uma das características do trabalho neste contexto: é ao Fórum Criminal que os horrores fruto da ação do homem são, geralmente, endereçados.

O serviço consistia no oferecimento de um dispositivo de escuta psicanalítico, cabível ao contexto institucional. Neste capítulo são discutidos as especificidades e limites deste dispositivo a partir da apresentação de sua realização. $O$ esclarecimento de tais especificidades e limites se faz obrigatório dado que sustenta a possibilidade de entendimento do campo, requisito/condição sem o qual não se faz possível a estruturação de um serviço psicológico. A questão-guia serve como oriente para o percurso desta apresentação. Para isso é discutido no que consiste escuta realizada a partir de exemplos práticos recortados em sua relação com os diferentes momentos da burocracia que sustenta tal dispositivo dentro da instituição judiciária. Acho importante esclarecer que tal escuta foi se desenvolvendo na prática cotidiana da instituição, a partir de experiências práticas, algumas frutíferas, outras não.

Retomando nossa questão guia: que escuta cabe oferecer neste contexto? Parece necessário afirmar algumas posições e suscitar precauções. De forma alguma o modelo proposto neste capítulo pode ser entendido como um modelo de escuta que pudesse ser realizado pelos diferentes trabalhadores que atuam na Justiça (juízes, promotores, advogados, defensores, pessoal dos cartórios etc). Longe de tentar consolidar um modelo universal de escuta institucional, esta dissertação (principalmente no presente capítulo) pretende oferecer algumas bases de um modelo de escuta possível para um psicólogo-psicanalista neste contexto institucional.

Há também que diferenciar a proposta aqui apresentada de uma garantia de escuta das vítimas durante o procedimento judiciário que, sustentando o objetivo de promoção da 
democracia e facilitação do fazer-justiça (da realização da Justiça), viesse dar conta das reivindicações políticas de maior participação das vítimas nos procedimentos judiciários criminais. Tais reivindicações clamam por uma maior participação das vítimas no rito jurídico propriamente dito.

Diferentemente, realizaremos um percurso acerca de como tal escuta interviu nos discursos desses usuários. As discussões sobre o quanto a presença de um analista também intervem no funcionamento judiciário pelo oferecimento de escuta aos usuários, assim como alguns recursos que a psicanálise parece oferecer para esta instituição, aparecem mais à frente.

Nossa questão guia deve também, a partir deste ponto ser complementada por uma outra questão, colateral: que falas são produzidas neste contexto? Tal questão não será fruto de um debate específico, mas é provável que o percurso apresentado adiante sobre a primeira questão seja enriquecido se o leitor puder ficar atento a esta última. Tal atenção parece agregar algum valor às discussões sobre a situação da violência familiar e das relações entre família, cidadania e Justiça na atualidade.

$\mathrm{Na}$ seqüência podemos acompanhar com detalhes o funcionamento da fase préprocessual $^{8}$ do Setor de Psicologia do JECRIFAM, que contava com dois momentos anteriores ao atendimento de fato: telefonema de verificação de risco e agendamento.

\footnotetext{
${ }^{8}$ O Setor de Psicologia oferecia também outros serviços como mediação de conflitos e atendimento a vítimas de violência sexual, em menor escala.
} 


\section{Telefonema de verificação de risco}

O primeiro contato com os usuários foi denominado de telefonema de verificação de risco, que consiste em, literalmente, telefonar para a pessoa responsável pela queixa a fim de verificar o risco de vida implicado na relação que gerou o procedimento judiciário (processo). Obviamente, apenas a pessoa que deu a queixa na Delegacia de Polícia é contatada neste telefonema.

Devido à grande variação da gravidade/intensidade da violência nos casos atendidos, existe pressa em realizar um primeiro contato, a fim de dar uma rápida resposta ao usuário marcando um primeiro posicionamento da Justiça.

A meta era conseguir contatar a pessoa em menos de 15 dias após a realização do $\mathrm{TCO}^{9}$, o que infelizmente nem sempre foi possível, por conta do enorme número de casos frente a um exíguo pessoal para a realização da tarefa (tanto do Cartório do JECRIFAM quanto do Setor de Psicologia). Esta era uma das tarefas realizadas principalmente pelos estagiários, após capacitação.

O telefonema consiste em: a afirmação de que o TCO chegara ao Judiciário e que já estavam sendo tomadas as devidas providências para o andamento do mesmo, apresentação e oferecimento do serviço de psicologia e, além disso, ainda se perguntava como estava a situação.

Nos casos nos quais a pessoa afirmou a possibilidade de ser morta por seu familiar, a primeira entrevista foi logo agendada, os outros casos passavam para a fila de espera, sendo atendidos conforme a ordem de chegada. A decisão quanto à pressa tinha, desta forma, a descrição fornecida pelo usuário como referência, o que pareceu ser a única medida viável de

\footnotetext{
${ }^{9}$ TCO, ou Termo Circunstanciado de Ocorrência é o modelo de queixa nas Delegacias de Polícia específico para esta temática, é correlato ao do Boletim de Ocorrência (BO) para casos de menor potencial ofensivo.
} 
avaliação dado que os TCOs não contêm informações detalhadas sobre a situação atual dos casos.

Falar sobre fila de espera em serviço público causa certo incômodo, mas por conta das limitações já supramencionadas foi recurso importante para a organização do Setor de Psicologia. Infelizmente é de conhecimento comum que este não é um caso isolado, mas que em muitos outros serviços públicos encontramos situações parecidas e que a prática de filas de espera, por pior que possa parecer, acaba sendo recurso imprescindível para a estruturação de diversos serviços.

Este modelo de telefonema foi especificamente criado em 2005, após um trágico incidente no qual uma pessoa que demandou ajuda para a Justiça foi assassinada antes do procedimento judiciário sequer chegar ao Setor de Psicologia (neste período muitos processos ficavam parados na malha burocrática do cartório, que chegou ao absurdo de 24.000 processos para sete funcionários! $!^{10}$ ). À frente há uma explicação mais pormenorizada sobre esta característica do contexto.

Os telefonemas são, portanto, momento muito delicado do procedimento, uma vez que há alguma exposição ao risco de re-incidência de fatos violentos. Podemos partir da percepção de que tal atividade afirma o valor vida como principal referência.

O que a experiência mostrou é que tal atividade não influía de forma a atrapalhar ou impedir o trabalho que era desenvolvido posteriormente. Antes, esse telefonema parecia constituir um primeiro campo de referência, um primeiro vínculo. Algumas vezes já fazia a função de uma intervenção, que parecia engendrar o sentido de uma afirmação da presença da Justiça no campo do conflito:

“... que bom que vocês ligaram, já me sinto segura".

“Agora que a Justiça ta do meu lado...”.

“... preciso muito falar com vocês porque já não sei mais o que fazer...”.

\footnotetext{
${ }^{10} \mathrm{O}$ assunto foi pauta de inúmeras reportagens nos principais veículos de mídia à época, o que pressionou a presidência do Tribunal de Justiça a garantir algumas mudanças na proporção funcionário/numero de processos.
} 


\section{Agendamento}

O agendamento era realizado preferencialmente via telefone, mas nos casos nos quais este procedimento ficava impossibilitado ${ }^{11}$ era enviado um Oficial de Justiça que levava pessoalmente o comunicado convidando para entrevista de triagem. O telefonema tem a vantagem de evitar encontros desagradáveis, uma vez que muitas vezes ex-cônjuges trazem os(as) atuais companheiros(as) amorosos como acompanhantes, o que pode gerar desconforto e as vezes até mais desentendimentos. Há casos também, nos quais a situação está intensa a ponto das partes não poderem realizar uma entrevista conjuntamente. Por conta dessas possibilidades é sempre melhor perguntar anteriormente se os usuários, partes do procedimento judicial, aceitam participar de uma entrevista em conjunto.

\footnotetext{
${ }^{11}$ Muitas vezes as pessoas dão números errados nas Delegacias, ou então os números foram cancelados, ou a pessoa nunca se encontra em casa ou simplesmente não possui telefone.
} 


\section{Atendimento}

Os atendimentos realizados no Setor de Psicologia podem ser divididos em três fases: um primeiro momento de triagem, um segundo momento de intervenção psicológica contratada com os usuários e um último momento de encerramento.

O serviço de atendimento é um dispositivo de trabalho psicológico fundamentado em escuta e intervenção que era oferecido aos usuários do JECRIFAM. Este dispositivo oferecia atendimentos individuais, para casais e grupos familiares. Estes atendimentos não consistiam em psicoterapia, uma vez que não tinham como meta cura, adaptação ou correção. O objetivo era realizar um pequeno número de encontros suficientes para: oferecer espaço propício para uma responsabilização pelo percurso na instituição Judiciária e dar início, ou continuidade, à elaboração das marcas e traumas advindos das violências, perdas e conflitos.

Por "espaço para uma responsabilização pelo percurso na instituição" pode se entender o oferecimento da presença do psicanalista como espaço para que o sujeito dirija suas falas partindo da consideração de que a passagem pela instituição judiciária causa efeitos em seu psiquismo.

Isso ocorre porque o fato de estar submetido à norma operacional do rito judiciário não implica que cidadão deixe de poder ser escutado em sua dimensão de sujeito de desejo e gozo. O oferecimento de escuta para esse sujeito desejante amplia a possibilidade do cidadão experimentar essa vivência na Justiça como um percurso que faça sentido ali onde articula as diferentes posições subjetivas que vai tomando, ou seja, tem um "preço": uma responsabilização sobre a construção de falas acerca da realidade na qual se encontra/vê inserido.

Faz-se necessário sustentar que o modelo de trabalho ora apresentado, portanto, não é igual a uma análise mas opera como uma análise no que isso é possível dentro de uma 
instituição, sendo mais bem descrito como um dispositivo de atendimento psicológico institucional cuja principal referência é a Psicanálise.

Ao longo deste capítulo são apresentados casos clínicos nos quais fica a impressão de que alguns momentos o dispositivo funciona igual a uma análise enquanto que em outros momentos funciona diferente. Apesar dessa impressão de diferentes momentos, há que sustentar que uma condensação dos papéis de analista e ator institucional está operante continuamente no exercício desta função.

As dificuldades da sustentação desse paradoxo podem ser representadas pela seguinte questão: como se responsabilizar por esta sobreposição? Diante desta questão somos rapidamente levados a pensar nos dispositivos consagrados: análise pessoal e supervisão. Sim, tais dispositivos se apresentaram na experiência concreta como condição para a realização do trabalho. Mas que outras condições para a realização desta função podemos elencar? Algumas já foram apresentadas, mas vale retomar: sigilo, legitimidade institucional, técnica, desejo, diálogo com outros atores institucionais. Mas a principal condição parece ser a ética. Esta ética, como já foi dito, se realiza a partir da assunção deste lugar que condensa as posições de psicanalista e psicólogo.

Outro ponto no qual se pode encontrar um limite institucional a este dispositivo é que sua realização se dá em curto prazo para a grande maioria dos casos. Por curto prazo entendase o período cumprido preferencialmente de dois a quatro meses. O tempo de um sujeito em um trabalho psicanalítico não pode ser pré-determinado, porém a experiência mostrou uma média variando entre 4 e 15 encontros para a realização do trabalho contratado. Geralmente após este período as questões em andamento são encaminhadas para outros serviços, mais pertinentes.

Além disso, para 32\% dos casos foi realizada apenas uma entrevista. Estes casos comportam: aqueles que com apenas uma entrevista conseguiam se assenhorear de uma 
posição em relação à Justiça ou já vinham com um posicionamento pré-definido, entre os quais haviam aqueles que se interessavam por algum trabalho psicológico mas preferiam realiza-lo em outra instituição e eram encaminhados; aqueles que não se interessavam pelo serviço oferecido; aqueles que apesar de demonstrarem interesse não tinham condições de participar do serviço (geralmente por conta da distância e/ou turno de trabalho), que também eram encaminhados para serviços que os pudessem atender nos fins-de-semana; e, ainda, aqueles que não tinham condições de sustentar um trabalho com atendimentos agendados, principalmente moradores de rua, os quais também eram encaminhados para serviços mais acessíveis.

A borda entre triagem e atendimento nem sempre fica clara, mas geralmente é possível se identificar o momento desta passagem de um dispositivo ao outro pela consolidação de um contrato de trabalho. Em uma análise se diria: pela entrada em análise, o que não é o caso aqui. No contexto do Setor de Psicologia do JECRIFAM tal contrato de trabalho só se justifica se a demanda do usuário estiver articulada à sua passagem pela instituição judiciária e/ou ao que motivou sua busca nesta, suas expectativas. A dissolução/atravessamento destas articulações, no sentido da responsabilização, se presta à função de referência para o término do trabalho junto ao Setor de Psicologia.

Por uma responsabilização que implica em dissolução/atravessamento de tal articulação entenda-se: o produto de uma pesquisa de análise (separação) dos conglomerados condensados de tendências que encontram satisfação nesta busca na Justiça. Isso de forma alguma quer dizer que o cidadão deva abrir mão de suas motivações mas, antes, que possa passar a se assenhorear de tais motivações e sustentar o endereçamento à Justiça apenas daquelas que achar mais pertinente.

Mas quando e como se dá tal dissolução? Os dois temas mais recorrentes que aparecem "amarrados" a tal referência são: a decisão de dar continuidade, ou não, ao 
procedimento judicial e a aproximação da data da audiência. Cabe lembrar aqui que o procedimento judicial no JECRIFAM é condicionado à representação da vítima, ou seja, a qualquer tempo a vítima pode se manifestar no sentido de pedir o encerramento da ação penal em andamento, por um simples encerramento ou quando da concretização de um acordo com o acusado.

Logicamente existe uma série de cuidados para a verificação da possibilidade desta vítima estar sofrendo algum tipo de ameaça ou pressão para a renúncia ao direito de representação, mas não é por este caminho que nos aproximaremos do tema em questão. Nem, tampouco, caberia a interpretação de que um objetivo do serviço seria essa renúncia, longe disso, aparentemente o efeito do dispositivo é incrementar e ampliar as possibilidades de falar sobre referências em jogo nestas tomadas de posição. Interessante é notar que apesar de tornar o campo mais complexo, tal incremento parece ajudar os usuários a melhor se situarem. Sobre a aproximação da data da audiência cabe, desde já, apontar que coloca a função da pressa em movimento. Algumas considerações sobre o tempo e a pressa aparecem durante o relato dos casos.

A entrevista de triagem consiste, assim, na apresentação e oferecimento de um serviço de atendimento psicológico para os usuários. Além disso, algumas dúvidas dos usuários sobre o funcionamento da instituição judiciária poderiam ser esclarecidas. A triagem seria o momento de entender junto ao(s) usuário(s) a pertinência e o porquê de pedidos e expectativas em jogo, na pertinência de um serviço psicológico-psicanalítico, no que isso poderia se articular à(s) expectativas(s) destes usuários em relação à/por Justiça, e realizar o encaminhamento para o dito serviço, ou seja, a triagem seria o momento de, havendo interesse e pertinência, "contratar" com os usuários um trabalho, delimitando seus objetivos, previsão de tempo, periodicidade etc. 
Poderia ser, mas não apenas, porque na prática a experiência mostrou outras tendências, uma vez que a triagem mostrou-se também como intervenção especialmente efetiva, o que nos possibilita fazer uma primeira aproximação do modelo do serviço à clínica tradicional. Além disso, é possível acompanhar as contribuições da Psicanálise neste "momento" do percurso na instituição.

Na grande maioria dos casos a triagem se apresentava como um primeiro momento de desabafo por parte dos usuários e já se operava um atendimento, a palavra acolhimento (na moda atualmente) talvez fizesse até mais sentido do que triagem. Isso porque se por um lado se tratava de um primeiro contato oficial da instituição, por outro, ao oferecer uma escuta para as queixas e pedidos presentes nos discursos dos usuários já se começava a escutar nestes discursos algo além da concretude imaginária de tais pedidos, posto que apontavam também para demandas inconscientes e tentativas de inscrição das singularidades.

Por estes motivos, desde o primeiro encontro o Setor de Psicologia se apresentava como lugar oportuno e legítimo de se romperem alguns silenciamentos. As dinâmicas familiares se apresentavam de forma a poder se verificar que geralmente algo ficava não-dito no dia-a-dia das famílias.

Em alguns casos o efeito da violência era tão intenso que o usuário não conseguia por em palavras o que havia ocorrido. Alguns casos que chegaram ao Fórum como denúncia de violência de menor potencial ofensivo acabaram por revelar-se como situações de estupro, tortura ou cárcere privado. A função do psicólogo-psicanalista, por sua posição ética, não era de fazer a denúncia pela pessoa, mas indicar o caminho para que o usuário a fizesse (junto ao Ministério Público), se achasse pertinente, uma vez que esse usuário pudesse portar um discurso de queixa sobre os ocorridos. 


\section{CASO 1}

No caso de Caroline, 21 anos, atendida no final do ano de 2005, um trabalho desta ordem se desenvolveu. Caroline chegou ao Setor de Psicologia encaminhada pelo juiz, que teve que adiar a primeira audiência pela ausência do acusado, mas não deixou de notar que a moça parecia estar sem condições de participar do rito, pois se apresentava "muito triste, calada e perdida" para participar da audiência, "não conseguindo responder ao que lhe era perguntado", o que havia preocupado sobremaneira os operadores do Direito presentes. A prática em questão, análoga à traigem/acolhimento, recebeu o nome de atendimento de emergência, no momento deste caso já constituída como prática corrente que apesar de não ser constante ocorreu também com alguns outros casos (dezenove no total), cada qual por motivos diferentes. $\mathrm{O}$ que se pode identificar de comum a estes casos pode ser resumido a dois fenômenos: o aparecimento de discurso delirante (ou algo que parecia ameaçar irromper, como neste caso) e a emergência de um quantum de agressividade entre as partes que parecia ameaçar a condução do rito em andamento.

Chegando ao Setor de Psicologia no momento diretamente posterior à audiência, nos apresentamos, Caroline se sentou e disse:

"Já ta tudo bem, já to melhor agora".

E silenciou. Era uma moça jovem, bem apessoada, com algumas cicatrizes visíveis no rosto e nos braços e com uma postura "encolhida" (ombros caídos, olhar e cabeça baixos, pernas fechadas e braços protegendo o tronco) que aparentava timidez. O silêncio durou alguns minutos até que:

“Acho que já to melhor agora, posso ir?".

"Pode ir quando quiser, mas se quiser aproveitar este espaço para contar o que houve ou porque trouxeram você da audiência pra cá, eu estou aqui para isso".

"Acho que eles ficaram preocupados porque eu não conseguia parar de chorar". 
Um novo silêncio.

“Geralmente eles encaminham pra cá as pessoas com quem ficam preocupados, mas você disse que não conseguia parar de chorar".

"É que eu tava muito nervosa que eu achava que ele ia aparecer qualquer minuto... se ele aparecesse eu não ia agüentar... não posso ver ele...não posso...".

Chorava. Pegou o lenço sobre a mesa ao lado, em silêncio e se secou.

"Você quer me contar de quem ou do que você está falando?".

"É meu ex-marido, ele é muito mal... separei dele, vai fazer dois anos... me ameaça e fala que vai matar meu filho...".

Durante algum tempo apresentou uma série de frases e palavras entrecortadas, silêncios, suspiros e choros. Parecia que Caroline se aproximava de algum tema mais difícil de articular.

"Parece que você quer me contar alguma coisa, mas está difícil".

"Aí.. eu nunca pude falar isso pra ninguém que eu não sabia o que as pessoas iam fazer com isso... ele fazia sexo comigo a força... [eu] me trancava no banheiro com meu filho porque ele me batia... quando separei na verdade fugi pro interior porque ele sabia onde meus pais moravam e eu não podia ir pra lá que ele me achava...".

Após mais algumas considerações, organizadas, parou de falar novamente.

"Que você acha de continuarmos amanhã?".

No dia seguinte, chegou com 30 minutos de antecedência, acompanhada do filho de quatro anos, que durante o atendimento da mãe foi atendido por uma estagiária, a pedido da mãe que o trouxe pois estava preocupada com a possibilidade possíveis traumas. Após entrar na sala, Caroline começou:

"Pensei muito ontem... que tem vocês aqui e por isso que eu trouxe meu filho, que eu to preocupada com ele dele ter ficado traumatizado...".

Após afirmar a presença a quem se podia referir continuou, não se aprofundou nesses possíveis traumas do filho, mas contou sua história:

“... tinha treze anos, ele passava na oficina do meu pai, nós teve amizade, ele falou que gostava de mim, ele disse que ia me fazer feliz... me pediu uma prova de amor, ter 
relação com ele, eu fiz e depois ele me bateu e eu escondi de todo mundo... se eu falasse ele matava eu e a minha familia... daí a gente casou, achei que ia melhorar, mas tinha medo... aí tive meu filho e achei que ia mudar... todo esse tempo eu não tinha pensado mais nisso, quando vinha lembrança tentava esquecer, pensar em outra coisa... depois de ontem fiquei pensando e lembrei de muita coisa ruim que ele fez comigo... ele me batia e fazia o que queria comigo... era que nem uma escrava pra ele, tinha que servir... quando ele saia me prendia numa corrente pra não fugir com meu filho... meu filho também tem medo dele... eu pensei ontem que se tinha alguém que eu pudesse falar disso era com o senhor...".

Como no primeiro atendimento parecia que neste momento entrávamos numa área mais instável, emergiram algumas palavras desconectadas ou pela metade (despedaçadas), choro, uma grande dificuldade de falar. Novamente a afirmação de uma presença a quem podia falar, o que parecia garantir alguma segurança para Caroline se aproximar novamente desses conteúdos desarticulados. Depois de uma intervenção do psicólogo-psicanalista, prosseguiu:

"É que ele fazia uma coisa comigo e com meu filho, acho que não da pra falar isso, nem pro senhor... isso não existe, não pode existir coisa assim tão ruim...”.

"Eu saí de casa depois que vi meu filho segurando a arma dele... nem sei se tinha bala, mas não pude suportar... aí quando ele saiu consegui fugir...”.

“... que ele fazia uma coisa... fazia sexo comigo a força na frente do meu filho e fazia meu filho ficar olhando... ele gostava disso... fez muitas vezes... não acredito que consegui falar isso...".

Um ponto a se atentar diz respeito a esta aproximação a um material tão difícil de colocar em palavras. Quando se trabalha com violência muitas vezes há que oferecer um espaço para que algumas experiências mais difíceis sejam colocadas em palavras, um trabalho de inscrever simbolicamente algo que ainda parecia muito desarticulado. Esse movimento de simbolização se apresenta como condição para a realização deste trabalho, posto que o psicólogo-psicanalista trabalha com a fala do usuário, o que, no entanto, não quer dizer que a pessoa deva falar, no sentido da obrigação. É importante respeitar a disposição e o tempo que o sujeito leva para a realização deste trabalho. 
Foi contratado com a usuária um acompanhamento, que foi breve e ao seu término gerou um encaminhamento para um tratamento psicológico em outra instituição, pertinente, a partir da seguinte declaração: "preciso cuidar de tudo isso que eu sinto só de pensar no que aconteceu... de uma ajuda para reconstruir minha vida e a do meu filho a partir daqui...".

Outro tema que pode ser abordado a partir deste caso é o do tempo do sujeito. Quando chega a hora de finalizar um trabalho o caminho é legitimar este partir. No encontro com a instituição, que está estruturada com seus tempos e burocracia (que, aliás, também tem seu tempo), parece haver uma tendência quase que imediata que tais tempos institucionais façam uma função de verdade quando do encontro com o usuário. Mas quanto ao tempo do sujeito, o que acarreta submetê-lo a essa pressa letárgica ${ }^{12}$

Em uma análise sob orientação lacaniana, o tempo que se presta à função de referência para a direção do tratamento não é de forma alguma o tempo cronológico (como aparece representado pela difundida imagem do analista encerrando a sessão exatamente aos 50 minutos de sessão com a frase: “nosso tempo acabou!”). Antes, o analista fica atento para uma dimensão do tempo que extrai sua lógica do funcionamento do inconsciente. Lacan nomeou como tempo lógico esta referência do trabalho psicanalítico, tempo lógico que pode ser dividido em três etapas: instante de ver, tempo de compreender e momento de concluir (LACAN, Escritos, 1998, pg. 204). Sustentar no trabalho de um analista em instituição o tempo lógico como referência para o trabalho parece agregar importante valor, é possível supor que se trata de uma condição de trabalho, desde que não se esqueça dos limites de tempo institucionais.

Mas como sustentá-lo operativamente no contexto institucional? Ou seja: como sustentar esta referência nas decisões quanto ao tempo de cada atendimento e tempo do percurso junto ao Setor de Psicologia? O primeiro ponto depende da formação/experiência

\footnotetext{
${ }^{12}$ A notação pressa letárgica é uma tentativa de nomear a operação temporal da burocracia institucional, na qual um processo urgente pode perdurar por anos, mas que ao mesmo tempo em cada ritual ou dispositivo opera da maneira mais rápida possível, muitas vezes "atropelando" o cidadão.
} 
clínica do profissional (ética e técnica), mas em geral não sofre interferências de outros atores institucionais. É no segundo que a interferência do funcionamento institucional pode parecer complicar as coisas. A primeira saída encontrada foi investir no diálogo com o resto da equipe da instituição. Quando ficaram patentes as limitações da possibilidade de um tempo de trabalho justo, a partir dessa referência dialógica, a indicação passou a ser: levar ao usuário a situação. Levando a dificuldade diretamente para o usuário abre-se a possibilidade que este usuário se responsabilize pelo modo que realizará o trabalho no Setor de Psicologia e seu percurso na Justiça tendo por referência esses limites institucionais.

Sobre o tempo do sujeito cabe apontar também o detalhe do agendamento do retorno para o dia seguinte. A decisão foi tomada levando em conta dois fatores articulados: ainda não havia clareza de um diagnóstico diferencial e ficou perceptível que a aproximação à temática poderia ter um efeito desagregador. Abrir um determinado campo de articulações psíquicas pode levar a uma aproximação intensa a um material quase insuportável, o que pode gerar um efeito devastador como até o desencadeamento de uma psicose. A estratégia de retomar o trabalho em regime de urgência (que geralmente causa algum transtorno na agenda do profissional) visa: possibilitar o acompanhamento da evolução dos efeitos de tal aproximação e, ao mesmo tempo, é responsabilidade do profissional que direcionou a essa aproximação, no sentido de uma afirmação mais ou menos como: "nos aproximamos juntos deste material difícil, então me coloco à disposição para tratarmos dele juntos”.

Há que atentar, também, que outras atuações relativas às articulações com a instituição também emergem de maneira profícua: falsear, escamotear, inventar, apagar, desvalorizar, esvaziar, esquecer etc. A aproximação ao momento da determinação judicial provoca a criatividade do homem a patamares incríveis! Tal aproximação também influi na pressa dos usuários. É um momento de concluir com hora marcada. 
A questão do tempo incide em todos os atendimentos. Especificamente neste contexto, nos casos de atendimentos a casais, outra característica do tempo pode ser observada: a produção massiva de falas acusatórias ou denunciantes parece promover um efeito de aceleração da emergência das questões subjetivas. Aquilo que aparentemente opera como perversidade, ou seja, o apontamento de uma divisão ou de uma falta, no outro, também pode ser escutado como a "abertura de uma porta", cujo caminho consiste em trabalho de responsabilização pelas realizações de desejo e o gozo em jogo.

O apontamento de uma falta ou divisão no outro, que se presta nas relações humanas à função de agredir, quando na presença de um analista, pareceu abrir campo para uma responsabilização, tomando-se por base que tais faltas e divisões são ancoragem destes discursos produzidos e apontam para os investimentos libidinais ${ }^{13}$ que sustentam os vínculos em jogo. Para além de apontar para uma possível carência ou incompletude, já são a apresentação de uma questão, a questão do desejo, que escapa em frases que podem ser traduzidas por: por quê reajo desta forma? O que posso fazer com essa falta? O que, ou onde, me mobiliza? O que quero com isso? Ou seja, se presta à função de dar direção ao trabalho, assim como uma porta que se abre, e à percepção de tal abertura um caminho se descobre e permite avançar nessa direção. Tal direção, vale lembrar, é uma direção à qual o sujeito vê-se implicado, pois que é direção da implicação a seu desejo.

Tais agressões operam também, nestas dinâmicas familiares, um efeito de provocação: de provocação da reprodução em ato de determinadas cenas. Aparentemente estas dinâmicas familiares repetidamente reproduziam tais cenas, à maneira de uma fixação. Freud, em Recordar, Repetir e Elaborar (1914), retoma e precisa as afirmações que já havia apresentado em Fragmento da Análise de um Caso de Histeria (1905), e propõe que a atuação do paciente em análise renova a transferência, realizando a fantasia inconsciente:

\footnotetext{
${ }^{13}$ Sobre a economia dinâmica dos investimentos libidinais, recomendo a leitura de Os Três Ensaios Sobre a Sexualidade, in: Edição Standard Brasileira das Obras Psicológicas Completas de Sigmund Freud, de Sigmund Freud.
} 
podemos dizer que o paciente não recorda coisa alguma do que esqueceu e reprimiu, mas expressa-o pela atuação ou atua-o (acts it out). Ele o reproduz não como lembrança, mas como ação; repete-o, sem, naturalmente, saber que o está repetindo. (Freud, 1914).

Temos assim, que ali onde o sujeito se apresenta propondo algo da ordem de uma denegação, posto que apontar a divisão no outro é forma de não se haver com a sua, no mesmo tempo produz laço social, ou seja, ali onde vemos uma perversidade operando podemos encontrar também um sujeito que tende para a política. Trata-se, essa perversidade, de uma tentativa, um tanto complicada, de inserir a marca de sua singularidade em um laçosocial a partir da mostração da divisão do outro.

Em alguns casos parecia que a busca por Justiça era também a busca por alguém que: admirasse tal atuação e/ou intervisse em tal atuação. Quanto ao primeiro interesse, no qual aparece claramente apenas o intuito de uma mostração como uma vontade de gozo, se era a única operação à qual tais sujeitos se dispunham a se assenhorear a solução era manda-los embora: "vão gozar em outras vizinhanças". Mas a busca por um terceiro que pudesse intervir nesta dinâmica aparentemente já fixada justificava a proposição de um trabalho interventivo.

Outro assunto relevante para o entendimento do dispositivo é a informação: podemos perceber que ao invés de questões e pedidos de informação acerca do funcionamento da instituição judiciária geralmente os usuários portavam diversas certezas, muitas das quais equivocadas, o que complicava uma tarefa informativa de esclarecimento. Assim como nas entrevistas da pesquisa que constituiu o modelo do serviço, os cidadãos usuários traziam diversas expectativas em relação à Justiça, muitas das quais incabíveis/injustas para a instituição.

A posição do profissional (psicólogo-psicanalista) frente a estes posicionamentos difere de um informador ou pedagogo. Algo informativo parecia encontrar espaço para ser transmitido, mas é oportuno adiantar que tal tarefa tinha como complicadores: a sobreposição de papéis, o trabalho com a transferência e também o fato de encontrarmos alguma resistência 
aos informes por parte dos usuários. Freud disse ao discutir a Educação que é comum encontrar resistência quando da transmissão de informações, talvez por isso chegou a afirmar que a Educação é uma profissão impossível. Mas o que quis dizer Freud com isso? A proposta da Psicanálise é que tais resistências estão diretamente articuladas à constituição do sujeito. A noção de constituição do sujeito é pedra fundamental do trabalho analítico, e muitos trabalhos de diversos analistas incidiram sobre esta noção.

Podemos encontrar uma rica discussão, realizada por $\mathrm{Kupfer}^{14}$, sobre as contribuições de Freud à Educação. A autora remete ao texto O Mal-estar na Civilização no qual Freud trouxe o exemplo da dificuldade e resistência dos pais em assumir a sexualidade infantil dos filhos, tal resistência estando articulada ao esquecimento de sua própria sexualidade infantil, reprimida, a partir do que articulou que "as práticas educativas são determinadas pelos recalcamentos sofridos pelo educador, que incidem sobre a parte infantil de sua sexualidade".

Parece viável entender que se o sujeito se encontra inacessível para o interlocutor haverá resistência ao informe que poderia melhor situar o usuário quanto às suas possibilidades de posicionamento dentro da instituição. Mas que posição de referência sobre esta temática cabe ao psicólogo nesta chegada do cidadão à Justiça se a via da transmissão da informação parece fadada ao insucesso, desencontro ou incompletude?

A solução encontrada para a questão da informação pode ser dividida em duas frentes de trabalho: especificamente dentro do Setor de Psicologia e multiprofissional. Sobre o trabalho junto à psicologia, as afirmações dos usuários acerca da Justiça apresentavam uma primeira cena de encontro com a instituição, cena esta que servia como entrada para um trabalho junto às fantasias que estariam operando. A opção era, portanto, propor que falassem mais de tais cenas e de suas expectativas em relação à Justiça. Além disso, algumas informações sobre limites institucionais eram transmitidas pelo psicólogo-psicanalista. Um

\footnotetext{
${ }^{14}$ KUPFER, M. C. M. - Freud e a Educação (1997).
} 
ponto a ser elucidado é que nos momentos em que se optava por oferecer tais informações, estas serviam como material interventivo. Em alguns momentos ao afirmar algo sobre o funcionamento institucional provocava-se uma dialética ou uma retificação subjetiva ${ }^{15}$ ou, ainda, os usuários simplesmente deslocavam suas expectativas a partir desta nova referência, sustentando as mesmas posições subjetivas.

Sobre a dimensão multiprofissional do trabalho, esta se dava em conjunto com os outros setores do Juizado. Quando uma questão pertinente à instituição judiciária era dirigida, no sentido da realização de Justiça, eram acionados os outros setores do Juizado, pois não podemos esquecer que acesso à informação e realização de Justiça são direitos do cidadão, ou seja, a instituição tem o dever de realizar Justiça e bem informar o cidadão, mas não necessariamente o psicólogo-psicanalista tem tal missão.

A partir disso, casos com dúvidas já articuladas eram encaminhados, principalmente, para os promotores do Ministério Público Estadual, profissionais legitimados e autorizados a explicar as possibilidades de cada caso ou tomar as atitudes pertinentes para a realização de alguma determinação institucional. Tais encaminhamentos ajudaram a consolidar com o passar do tempo um trabalho em equipe multiprofissional.

Outra particularidade desta fase do trabalho deriva do fato de que os TCOs (termos Circunstanciados de Ocorrência) geralmente contêm pouco mais de 10 linhas de relato, traduzidos pelo escrivão, quando muitas vezes estamos falando de casos com mais de 30 anos de casamento.

Por isso, principalmente durante a triagem, um caminho era pedir um breve relato para os usuários sobre o que ocorrera e sobre como as coisas se desenrolaram após os fatos. Um tema recorrente para grande parte dos usuários era o apontamento de transformações nas dinâmicas familiares. É possível descrever os modelos mais comuns destas narrativas, sendo a

\footnotetext{
${ }^{15}$ Esta noção é explicada mais à frente.
} 
transformação atribuída a: o fato violento em questão (ou a outro fato violento articulado), os efeitos do TCO (ou BO) e a separação do casal. Abaixo algumas frases tiradas de diferentes prontuários.

"Desde que ele me bateu nunca mais dormi com ele... não consigo... quando ele chega perto fico gelada... nojo dele... aquele cheiro... acho que nunca mais vou poder ter um homem na minha cama...”.

"Depois que fiz o BO ele nunca mais me bateu... a gente briga sabe... eu também sou de discutir, não sou de abaixar a cabeça não... mas esse negócio de bater nunca mais...”.

“Olha nem sei por que fiz esse BO... acabou com a minha vida... ele foi embora de vez... meu filho nem olha mais na minha cara... era muito chegado no pai...”.

"Depois que a gente separou ela não me deixa mais ver as crianças... age assim por vingança... só quero ver minhas filhas...".

É possível afirmar, assim, que a triagem/acolhimento se configura como momento crucial do encontro entre os usuários e o Setor de Psicologia, chegando a ser considerado para alguns casos como o momento decisivo no qual algum efeito ocorrera junto a determinado usuário ou família.

Para aprofundar o debate faz-se importante lembrar que uma análise também conta com um momento inicial, anterior ao tratamento propriamente dito. Freud nomeou este momento como tratamento de ensaio. Foi Freud quem primeiro apresentou as diferenças em relação ao tratamento: "durante essa fase [de ensaio] deixa-se o paciente falar quase o tempo todo e não se explica nada mais do que o absolutamente necessário para fazê-lo prosseguir no que está dizendo". Lacan, posteriormente, re-nomeou este início de tratamento como entrevistas preliminares (Escritos, 1988). As entrevistas preliminares se configuram como momento decisivo no tratamento e já tem por base de seu funcionamento a associação livre. Nestas entrevistas se realiza um diagnóstico diferencial a partir do sintoma analítico proposto pelo paciente ao analista e do estabelecimento da transferência. 


\section{CASO 2}

O diagnóstico diferencial estrutural em uma análise presta-se à função de orientar a direção do tratamento. A referência para tal diagnóstico é a estrutura do Simbólico apresentada pelo analisante, isso porque é "no registro simbólico, onde são articuladas as questões fundamentais do sujeito (sobre o sexo, a morte, a procriação, a paternidade, a filiação) quando da travessia do Édipo", conforme nos lembra Quinet ${ }^{16}$. Um psicanalista realiza seu trabalho a partir da fala de seu paciente. Existem dois recortes fundamentais no trabalho do diagnóstico diferencial.

Um primeiro recorte incide sobre o modo de negação do Édipo e possibilita a diferenciação entre neurose, perversão e psicose. Tal diferenciação se faz necessária pois o modo de negação da falta constitutiva do Outro da linguagem irá determinar o que se pode esperar de um trabalho psicanalítico. É com o retorno disso que foi negado que se conduz um tratamento, ou seja, com sintoma (neurose), fetiche (perversão) ou delírio (psicose). O tipo de trabalho proposto junto a cada usuário será portanto diferente, respeitando as características da produção deste sujeito. Quando não há a proposição de um sintoma analítico o diagnóstico diferencial aponta para uma estrutura não neurótica ou, apenas, para a falta de interesse em fazer análise.

Um segundo recorte, dentro do campo das neuroses, também seve como guia para a condução de uma análise: a diferenciação entre neurose obsessiva e histérica. A diferença na produção do sintoma obsessivo (anulação do desejo) e histérico (insatisfação) também traz implicações à forma da condução do trabalho.

A função diagnóstica também é importante neste contexto, mas requer alguns cuidados específicos. Isso porque é na Justiça que se determinam as interdições civis, geralmente

${ }^{16}$ QUINET, A. - As $4+1$ condições de análise (1990). 
fundamentadas em diagnósticos psiquiátricos. De forma alguma um serviço que oferece escuta, em um trabalho nos moldes de um tratamento, poderia se prestar ao uso de diagnósticos com esta função.

Segue o relato de um caso no qual a partir do diagnóstico diferencial estrutural realizado na triagem se conduziu um trabalho que ajudou uma família em seu percurso pela Justiça. Essa família foi atendida no Setor de Psicologia em 2005 por um período de sete meses, num total de 31 entrevistas.

O grupo familiar morava na mesma residência e mantinha as seguintes relações de parentesco: Mariana, 64 anos, era mãe de Luiz, 35 anos, este era casado com Rita, 52 anos, e eram pais de Luizinho, de 13 anos. A queixa descrita no TCO continha apenas declaração de Mariana, que afirmava que o filho agredia a todos na casa e que na data dos fatos a havia agredido sem motivo aparente.

Apenas Mariana compareceu a primeira entrevista de triagem. Relatou que tinha um filho com "doença... bi-polar... já falaram até em esquizofrenia..." com quem se desentendia diariamente, quando questionada respondeu "meu filho é louco mesmo". Narrou o incidente que deu origem à queixa na Delegacia:

"Ele havia comido toda a comida... sempre acaba com tudo que eu compro... quando fui dar um corretivo nele, porque com o Luiz só batendo pra ele entender, ele segurou minha mão... apertou forte... ficou até um hematoma... ai dei queixa... tem que me respeitar... ".

Explicou que "educava" seu filho, de 35 anos, com a cinta, pois era o "único jeito" de fazê-lo "obedecer" e "respeitar". Após comentar um pouco o dia-a-dia familiar dirigiu pedidos à Justiça:

“... quero que arranje tratamento para ele... já foi em todos os lugares e não conseguiu... alguém que dê um limite pro meu filho... a Justiça é a última saída... alguém que o ajude...”.

Os pedidos de Mariana não são exclusividades deste caso: é bastante comum o pedido por um limite ser endereçado à Justiça nesse contexto (principalmente à figura do juiz). Assim 
como um pedido de que a Justiça possa obrigar alguém a fazer um tratamento e se transformar. Abaixo algumas frases de prontuários de outros casos ilustram essas recorrências:

“... quero que o juiz ponha um limite nele pra ele parar de me bater...”.

“... quando bebe fica descontrolado... queria que a Justiça fizesse ele parar de beber”.

“... ela faz tudo isso pra se vingar... queria que você falasse com o juiz pra ela parar com isso".

“... ele tem que mudar, o juiz vai mandar ele...”.

“... é nossa última esperança... se a Justiça não fizer ele mudar acho que então...”.

“... e você falar pro juiz obrigar ele a fazer um tratamento...”.

“... vocês não podem internar ele até ele... se o juiz mandar...”.

“... o juiz não pode arranjar um lugar pra internar ele?”.

“... se vocês aqui da Justiça arranjarem um tratamento pra ele fico com ele...".

Vemos que o pedido por um tratamento aparece, o que é constante, articulado à função da determinação judicial, ou seja, pede-se que o juiz determine que alguém faça um tratamento. Tais pedidos apareciam principalmente em casos de alcoolismo, drogadição e discurso delirante. Entramos aí numa ceara difícil. Um dos principais valores agregados à Constituição Federal de 1988 foi a inclusão da Declaração Universal dos Direitos Humanos como referência fundamental. Nesta Declaração encontramos claramente a saúde como direito e não como dever. Além disso, é de conhecimento dos profissionais da área da Saúde Mental (psicólogos, psicanalistas e psiquiatras) que um encaminhamento "forçado" dificilmente resulta em uma adesão efetiva ao serviço. A discussão sobre esta pauta rendeu alguns diálogos com a juíza diretora no ano de 2004, dos quais foi tirada uma posição política do JECRIFAM: não haveria determinações de encaminhamentos para a área da saúde, mas recomendações.

$\mathrm{Na}$ primeira entrevista de triagem com Luiz, este se apresentou agitado e intenso, fez diversas gesticulações, levantou três vezes da cadeira, falou todo o tempo em alto volume, além de produzir um discurso desenfreado: 
“... sei que apanho direto dentro de casa... ela mesmo me agride... chega e diz que foi agredida... meu pai faleceu em 2003... ajudava com 1.300 por mês... pagava o aluguel... to me aposentando por problema psicológico... sem trabalho desde 2002... a empresa me mandou embora... se utilizaram de mim... me aproveitaram de mim... antes tava em hospital dia... posso falar sem interrupção? Assim a coisa fica dificil to tentando falar e você me interrompe... conversei com uns amigos da escola... falaram que tinha que trazer provas para Justiça, que só acreditam em quem tem todas as provas... trouxe tudo comigo... você não vai ver agora? ... depois, depois... ela me bate com a cinta... ela fala: 'quero que você morra, quero te matar, vou te dar um tiro na cabeça' e bate... dói... to com a cara inchada porque fiz muita musculação na adolescência... achei que ia ter mais oportunidade com meu pai se me casasse... que fosse me respeitar mais, me dar um carrinho e um emprego... nada... ".

A constante troca de assunto sem aviso prévio, aparentemente sem encadeamento chamava atenção. Após rude insistência espalhou sobre uma mesa da sala diversas provas enquanto se justificava:

"Só consegui encontrar as de matemática, de biologia e de história... pode ver as notas aqui... é, essas não estão muito boas... mas olha meu boletim, acho que vou pegar no máximo três recuperações...”.

Luiz cursava, nesta época, o supletivo do $2^{\circ}$ ano do ensino médio. A apresentação das provas escolares era algo inédito que apontava para um uso delirante do significante "provas". Por uso delirante da linguagem podemos entender uma articulação entre significante e significado que exclui o fato de um significante como tal não significar nada fora de um contexto. Luiz parecia não poder usar esta palavra prova em sua dimensão simbólica, metafórica. Nesta articulação de Luiz o significante "prova" aparece "colado" a este determinado significado, operando como uma certeza. Uma outra possibilidade seria Luiz ignorar o uso jurídico do termo "prova", o que no entanto parecia improvável dado sua idade, classe social e grau de instrução.

Após as explicações sobre o porquê das baixas notas das provas apresentadas, puxou uma fotografia do envelope e disse:

“Aqui tem mais uma prova... olha só ela aqui... dá pra ver a maldade...". 
A foto apresentada mostrava os quatro (Mariana, Luiz, Rita e Luizinho) abraçados sorrindo, era uma bela fotografia de família, ele explicou que fora tirada em uma viagem de férias e mostrou onde localizar a maldade: no céu azul sobre sua mãe e também no rosto dela. Estaria Luiz enxergando algo nesta foto para além daquilo que se apresentava? O termo técnico para um fenômeno deste tipo é alucinação. Desde esta primeira entrevista já havia material suficiente para a suposição de um diagnóstico de psicose, o que se confirmou nas entrevistas seguintes.

Retomando o pedido que sua mãe endereçou à Justiça desde a primeira entrevista (“alguém que dê um limite para ele") à luz dessas constatações, podemos nos colocar a questão: estaria Mariana pedindo a inscrição do seu filho na norma fálica? Ou seja: que a Justiça, ou o Setor de Psicologia, o transformasse em neurótico? Neste ponto cabe retomarmos a posição política da psicanálise, consolidada após diversos debates e reflexões éticas, qual seja: não se pode transformar um psicótico em neurótico. Mesmo tentar tal intento poderia se configurar como grave violência subjetiva.

Não entrarei no mérito de discutir a questão do momento de escolha estrutural, se é escolha ou não, quando se dá e sobre as possibilidades de intervenção e promoção da instauração da referência simbólica, posto que tal debate ainda hoje causa algumas celeumas no meio psicanalítico e não ajudaria na matéria em questão. Aqui se trata de um caso de um adulto que se apresentou consolidado em uma posição a partir de uma escolha estrutural que forclui o nome-do-pai.

Uma das principais particularidades da direção do tratamento para casos como este toma desta consideração sua referência. Vemos no dia-a-dia da clínica que os atos e posicionamentos delirantes e/ou alucinados re-atualizam tal escolha, ou seja, quando cobrado pela assunção de uma posição simbólica o paciente nesta condição atua novamente excluindo a função simbólica, o que implica que um analista não deva esperar uma responsabilização ao 
estilo das referidas ao nome-do-pai em um trabalho com a psicose. O trabalho segue por outra direção.

Por nome-do-pai quanto ao diagnóstico diferencial, entendemos a inscrição da função paterna, simbólica, no aparelho psíquico que sustenta a entrada na norma fálica quando da travessia do complexo de Édipo. Trata-se da inscrição de outro referente (significante) que substitui o primeiro significante, materno, operando portanto qual uma metáfora. Nas palavras de Lacan, em seu seminário As Formações do Inconsciente: "O pai é, no Outro, o significante que representa a existência do lugar da cadeia significante como lei” (pg. 202), e podemos acrescentar: como lei do Simbólico. Por lei do Simbólico temos portanto já duas referências: encadeamento e lugar.

Em não sendo a lei simbólica o único norteador do trabalho com as psicoses, a postura assumida é de oferecer a ajuda possível para que a travessia pela Justiça fizesse algum sentido e que fosse cuidadosa, no sentido de cobrar uma responsabilização possível de Luiz. Afinal, o que esperar do encontro deste modelo de discurso com o rito judiciário? O trabalho possível para um caso como este parte, então, de duas posições: não seria necessária a interdição civil (esta foi a postura para todos os casos) e que se ajudaria a estruturar condições para que o percurso pela instituição fizesse sentido. $\mathrm{O}$ andamento deste caso não será apresentado em detalhes, mas apenas um pequeno resumo com algumas observações pontuais.

A partir das entrevistas de triagem foi contratado um trabalho familiar com este grupo de usuários. Ficou acertado que focaríamos o trabalho nos conflitos familiares, principalmente da relação mãe-filho, e nos desdobramentos das dinâmicas de toda a família pois essa passagem pela Justiça poderia causar efeitos diretos nesta relação e nessas dinâmicas. O foco do trabalho contratado seria uma ajuda a esta relação mãe-filho e a passagem pelo contexto da Justiça, o que pareceu fazer sentido para todo grupo familiar. 
A saída encontrada para este caso, parecida àquela que foi utilizada em outros casos, foi operar com duas direções em vista: oferecendo um espaço terapêutico para a família e como um mediador "concreto", que indica os limites, do encontro desta família com a Justiça. Esta mediação se configurando como a abertura de um espaço de discussão com a família sobre as expectativas e possibilidades em jogo. A diferença, em relação a outros casos, está na assunção de uma posição mais afirmativa, que tenta não provocar enigmas e questões estruturais do sujeito. O posicionamento assumido pelo psicólogo operava no sentido de não supor um sujeito do inconsciente, mas orientar de forma direta o quê dessas expectativas não era cabível à Justiça e para onde deveriam ser dirigidas. Por terapêutico pode-se entender o oferecimento de um espaço que possibilitasse que as realizações de algumas tendências pudessem se transformar de atuações para o campo da palavra, principalmente em relação à Mariana.

Tal posicionamento sustentava como referência as impossibilidades de: Luiz estruturar uma demanda sob transferência e Maria conseguir alguém que inscrevesse seu filho na norma fálica. Um compromisso ético de um psicanalista é não prometer aquilo que não pode entregar. Lacan, em seu seminário sobre a ética da psicanálise, sustentou que o analista não pode desejar o impossível.

Nos atendimentos em família, dos quais participavam primeiramente mãe e filho, e depois os três adultos, diversas denúncias foram remetidas. Mãe e filho só convidaram Rita de maneira efetiva após dois meses de trabalho, e Rita demorou a aderir ao serviço, vinha uma vez, faltava outra, apenas ao final sustentou uma seqüência de atendimentos. Rita, mulher de Luiz, apresentava claros sinais de melancolia. Os principais problemas discutidos nesses encontros eram relativos aos conflitos familiares, em dado momento pararam de falar na Justiça. 
Aqui cabe um parêntese: na maioria dos casos atendidos, com as mais diversas configurações familiares e também individualmente, durante um período geralmente curto parece haver um esquecimento do contexto judiciário, os usuários se voltam para questões que parecem completamente desligadas do contexto institucional. Na maioria dos casos os próprios usuários se apercebem deste aparente desligamento, mas há momentos em que coube ao psicólogo-psicanalista "lembra-los" do contexto.

Os rumos da participação da família no dispositivo começaram a mudar quando Mariana começou a se responsabilizar pela ambigüidade com que atuava na relação com o filho, qual seja, ela o rejeitava no mesmo tempo em que não conseguia se separar dele. A dinâmica familiar, ao que parece, operava simultaneamente como uma montagem perversa e compensatória: errância, voracidade e erotomania de Luiz provocavam Mariana a atuações terríveis dirigidas a ele, que respondia intensificando tal quadro de Luiz, até que Mariana atuava uma violência que, de alguma forma, realizava/satisfazia ambos e estabilizava a situação.

Mariana começou a se questionar sobre essa dinâmica: "deve ter outro jeito da gente se organizar, viver como família...", e resolveu renunciar ao direito de representação, sustentando que construiu, ao longo de seu percurso no Setor de Psicologia, o entendimento de que toda a família precisava de tratamento. Foram encaminhados para a realização deste tratamento pedido. 


\section{CASO 3}

Um outro ponto importante da sustentação do dispositivo é o trabalho com a transferência. O estabelecimento da transferência é o marco de entrada em uma análise, e corresponde à produção de um sujeito suposto saber. A suposição de um saber sobre o ciframento inconsciente é condição para se instituir um sujeito da associação livre sob transferência, ou seja, é o que irá sustentar o endereçamento de fala em um trabalho que pretende a liberação de algum sintoma. O efeito da transferência é a emergência de um amor, dirigido à figura do analista. Este amor de transferência opera ao mesmo tempo como resistência à questão do desejo e como atuação da realidade sexual inconsciente. Portanto é no trabalho com a transferência que se realiza uma análise.

Em uma análise o estabelecimento da transferência marca o atravessamento da queixa na direção da constituição de uma demanda de análise. $\mathrm{O}$ atravessamento da certeza que sustentava a queixa para a emergência de uma questão se dá ali quando a presença do analista é requerida como garantia de que há um saber a se apreender ou decifrar acerca do campo estrutural que começa a se fazer observar, já que sua insistência e ambigüidades são apontadas pelo analista. Ocorre que ao se desfazer dessa posição de certeza e se questionar, o sujeito supõe a existência de um saber sobre estas estruturações, um saber que se coloca para além de onde vê daquele lugar que sente ocupar. Geralmente supõe que o analista tenha tal saber e endereça ao analista o pedido de acompanhamento nessa pesquisa que pretende "descobrir" tal saber.

Um analista escolhe acolher ou não aquela proposta de sintoma analítico endereçada por seu paciente. No entanto, seria impossível impedir a transferência, o que é agravado ao se fazer escuta para o sujeito do inconsciente quando das emergências dos lapsos e falhas na 
linguagem, posto que a provoca. Daí decorre-nos uma questão ética: qual o limite do trabalho com a transferência neste contexto? Quanto, ou o que, cabe apontar para este inconsciente?

Conforme já mencionado, neste contexto a escolha possível é por um contrato no qual serão trabalhadas as questões articuladas à busca na Justiça, cujo prazo será, portanto, pautado pelo atravessamento do suporte desta articulação. Desta forma, durante este percurso muitas questões do sujeito irão emergir articuladas a esta busca na Justiça, enquanto outras não, e se faz importante ajudar o usuário a localizar nestas incidências do sujeito seus endereçamentos, a fim de que possa se responsabilizar e, posteriormente, re-endereçar estas outras questões para onde melhor lhe convir. Mas cabe apontar que muitos pedem um trabalho que se proponha a acolher tais questões (análise ou terapia). Alguns chegam até a pedir que o psicólogo-psicanalista os atenda em seu consultório, o que deve ser barrado, evidentemente, no mesmo tempo em que abre a possibilidade de um trabalho cuidadoso de encaminhamento.

É possível se aproximar de um dos limites que se impõe ao trabalho com a transferência a partir da constatação de que a Justiça já é, de antemão, destinatária e garantidora de posicionamentos subjetivos. Os sujeitos já endereçam queixas, questões e demandas à Justiça, posto que já a supõe em alguma conta ${ }^{17}$.

Um primeiro ponto com o qual se depara constantemente neste contexto, e que contribui para uma leitura destas suposições, é uma diferença entre o que aparece (d)escrito no Termo Circunstanciado de Ocorrência, que faz supor o pedido por uma responsabilização legal daquele que é apontado como autor pelos fatos, e as falas sobre expectativas e pedidos dirigidos à Justiça. O que havia sido percebido na pesquisa que fundamentou a criação do Setor de Psicologia e a fase pré-processual se confirmou no dia-a-dia dos atendimentos. Aparentemente, nas Delegacias de Polícia os agentes estatais já "filtram" as queixas de forma

\footnotetext{
${ }^{17}$ Sobre as contas de um sujeito recomendo a leitura de O Calculo Neurótico do Gozo, de Christian Dunker.
} 
a escrever apenas o possível de ser enquadrado pela instituição judiciária, excluindo todo o resto da produção discursiva dos cidadãos.

Por um exemplo sobre este tópico, que articula alguns elementos da psicanálise e expectativas e endereçamentos à Justiça, podemos retomar o caso, atendido em 2005:

O TCO descrevia a queixa de uma mulher que declarava que: seu marido havia chegado embriagado em casa e a ameaçara, então ela se trancara no quarto com as duas filhas e que apenas no dia seguinte fora à Delegacia dar seu depoimento, declarando ainda que a situação de violência era constante e que quando o marido chegava embriagado precisava se trancar no quarto, posto que ele já a havia agredido fisicamente em outros momentos anteriores.

Arlete, mulher de 38 anos, veio para a entrevista de triagem junto com suas duas filhas, Carla de treze e Renata de dez anos. Aparentemente muito nervosa, Arlete insistiu que as filhas entrassem junto na entrevista, e logo após nos apresentarmos já começou a falar:

"Meu marido, ele ta preso na XX [cadeia] por causa de nós duas (apontou para a filha mais velha), por besteira... chegou em casa embriagado, falando besteira... me tranquei no quarto com minhas filhas... tava cansada do trabalho... ele não fez nada”.

O psicólogo-psicanalista, parte de um não saber sobre os contextos, sobre o que busca a pessoa que lhe dirige a palavra, a quem ela imagina que endereça suas demandas etc. A assunção desta posição de não saber é condição para a escuta de um psicanalista.

Pede-se, então, que fale mais sobre o assunto, de vez em quando que explique mais um ponto ou outro, optei por não colocar todas as falas do psicólogo-psicanalista, trazendo apenas o material apresentado pelos usuários:

“Ele gritava 'vou matar vocês'... e começou a gritar 'Carla... Carla' da terceira vez que ele gritou Carla desceu... gritos da Carla... desci e ele tava com a cueca nos pés, eu 
comecei a gritar 'ele ta tentando estuprar minha filha'... sem saber o que tava acontecendo...".

Chamava atenção a presença das filhas quando do relato da mãe, por isso, no momento em que Arlete afirmou "é isso", como que colocando o primeiro ponto final em seu discurso, foi perguntado às crianças como estavam se sentindo e se sabiam porque estavam ali. Carla tomou a palavra:

"a gente ta triste... viemos libertar o pai... ele não fez nada... ele é que nem criança”.

Após algumas poucas falas da filha Arlete retomou a palavra:

“... minhas filhas sabem de tudo da minha vida nunca escondi nada delas...”.

O modelo de família e transmissão entre gerações parecia não propor limites do que é apresentado/proposto às crianças, inclusive acerca de questões relativas à sexualidade. Haveria realmente uma dificuldade em se responsabilizar por estes limites? E quanto à tentativa de estupro mencionada? Este modelo sugerido pelo discurso desta usuária provoca uma questão que é importante e causa de uma das maiores dificuldades na inserção da Psicanálise dentro de um contexto de Justiça: as crianças estão ameaçadas ou recebendo tratamento não condizente com os pressupostos do Estatuto da Criança e do Adolescente? Como se posicionar frente a tais informes se eles emergiram num contexto de escuta sigilosa?

“As menina é muito pegada com o pai... fica agarrando o pai... como é aposentado passa o dia com elas... falei isso porque tava cansada... na minha mente seria só um castigo... ta sendo castigado e minha consciência não ta tranqüila... o que interessa pra mim é a inocência dele... o advogado não ta dando tanta importância no caso...".

Podemos perceber neste trecho emergência de um primeiro sinal de culpa, articulado à queixa de uma dificuldade de se responsabilizar por seu ato que dera origem a prisão do marido. Arlete nesta fala se apresentou dependente do advogado, como se estivesse em uma posição de imobilidade:

“tomo remédio pra síndrome do pânico... faz quatro anos... passo no posto com o psiquiatra uma vez por mês... com a psicóloga uma vez por mês... na minha cabeça era 
assim: ele ia pra delegacia, nós dormia em paz e ele voltava no dia seguinte mais calmo... ele não bebe todo dia mas quando bebe é terrivel... é isso".

Dificuldade em se responsabilizar, ignorância e não saber como dar conta da situação encontravam como subterfúgio um discurso médico (síndrome do pânico) que fazia função de uma ancoragem consciente?

“... só Deus sabe o que eu passo com aquele homem... já tinha um ano e três meses que a gente tava separado... morando junto... mas ele dizia 'se você sair eu te mato' e ficava me chamando de... porque tomo remédio sou louca... só quero falar a verdade...”.

É possível notar bastante ambigüidade quanto aos sentimentos em relação ao marido. Chamou atenção também o "falar a verdade" que apareceu como um significante que poderia ser um articulador ou representante da busca desta usuária na Justiça.

“... fui no fórum duas vezes... não consegui ver o juiz... não interessa o que vai acontecer comigo, interessa contar a verdade... ele não pode pagar por uma coisa que não fez... as testemunha nem conhecia ele e mentiu pro policial... apanhou muito na delegacia...".

A primeira descrição de uma posição de imobilidade, mais passiva, ganhava novos contornos quando da descrição de seus movimentos em busca da Justiça (histeria?). O quanto poderia esta usuária se responsabilizar pelas ações que já empreendia? Outro ponto que pareceu relevante é a descrição de uma suposta brutalidade por parte da Polícia, que parecia incidir confirmando uma clara posição do marido dentro de seu discurso: de vítima.

“... não sei porque a gente se esconde dele, ta tão embriagado que se tocar nele ele cai... tive uma crise e arranhei minha filha inteira... é ele que me controla, no ônibus quase quebro o fio... pensei em me matar...".

Novos materiais ambíguos, que à sua maneira já apontavam para uma divisão subjetiva.

“... esse homem, devo minha vida pra esse homem... era menina de rua... fui quase estuprada pelo meu pai... meu pai me deu duas opção: ou virava mulher dele ou rua... fui pra rua... minha irmã teve filho com ele... ele [marido] me tirou da rua, deu tudo e agora isso... fui eu que quase fui estuprada pelo meu pai, não ela [Carla].”. 
O surgimento de material profícuo para articulação de transmissões e repetições entre gerações é bastante comum neste trabalho, mas chamou a atenção o surgimento deste tipo de articulação já na primeira entrevista. Poderia esta mulher se responsabilizar pelo que lhe foi constituinte em suas vivências com a geração ascendente de forma a não trazer sua repetição apenas com o estatuto de uma queixa ou atuações?

A facilidade de trazer já numa primeira entrevista material tão íntimo chamou a atenção, tendo em vista que em uma análise tradicional isso pode demorar algum tempo a aparecer. Porém, em uma análise, desde a primeira entrevista, também já surgem temas que acompanharão todo o processo. Como nos lembra Nasio, em Um Analista no Divã, na primeira sessão o analisante já traz o tema que será trabalhado no final de sua análise. Isso ocorre porque um sujeito traz a questão que o levou à análise, mesmo que inconscientemente. Mas é importante também considerar que este contexto é diverso da clínica tradicional. E no que tal contexto poderia influir acerca desta temática?

Para além das questões já citadas acerca do tempo lógico no encontro com a instituição, outras considerações podem servir como referência: grau de escolaridade, alfabetização e classe social. Não há aqui a intenção de realizar uma profunda análise de todas as implicações destas temáticas. Porém, pessoas situadas em condições sociais menos favoráveis apresentam-se, constantemente, "agarrando" o que pode ser uma das únicas chances de serem escutadas. Isso se apreende, em alguns casos, por uma vinculação maciça (a esta "oportunidade") e por uma pressa (provavelmente derivada da experiência cotidiana de, nas "oportunidades que aparecem", ter que se explicar e posicionar em poucos segundos quando em um serviço público).

Retomando as considerações acerca dos limites do trabalho com a transferência neste contexto. Ocorre que enquanto na clínica tradicional o analisante primeiramente supõe no analista um saber aos moldes do saber de um médico, no contexto da Justiça Criminal 
também incidem outras suposições, que tem como referência a realização de Justiça, o discurso do direito e suas aplicações. Enquanto o discurso médico propõe como principal referência uma verdade, no ambiente jurídico a maior referência é a Lei, ou seja, a letra escrita que determina o que pode e o que não pode em termos de ato, o que inclui desde o princípio a noção de escolha. Para uma comparação, no discurso médico a escolha não aparece necessariamente como operador, o que torna possível sua aparente retirada do campo das referências. Esta relação médico-paciente foi pauta de diversos pensadores de outras áreas também, por exemplo, Foucault, em $O$ Nascimento da Clínica, considera que esta abordagem médica chega ao extremo de permitir em sua clínica a realização de uma relação instituição doença, o que implicaria em um apagamento total dos sujeitos em questão neste encontro. Mas não iremos por este caminho.

Podemos sustentar que algumas especificidades do discurso jurídico o diferenciam do médico: enquanto este se presta à estruturação de uma relação objetiva, aquele opera num campo dialógico referido por uma legislação escrita. Esta diferença tem suas implicações, que serão discutidas adiante, no capítulo Os (des)encontros entre os usuários do JECRIFAM e a Justiça.

Neste ponto da discussão entraremos na diferença de expectativas e suposições (discurso médico versus discurso jurídico). Ao nos debruçarmos sobre a história da Psicanálise, vemos com facilidade que o número de trabalhos e investimentos na pesquisa sobre a relação com a medicina são inúmeras desde Freud em suas Conferências Introdutórias e, portanto, o rigor atual portado pelos analistas sobre tal temática deve-se muito a todo este trabalho realizado. Como se sabe a Psicanálise é um método criado por um médico (Freud) e apesar de todos os esforços de diferenciação da Medicina, são utilizados alguns conceitos originários do discurso médico. Há, por isso, muito material escrito para consulta, do qual um dos valores é a sustentação da diferença dos campos de intervenção médico e psicanalítico. O 
mesmo não ocorre acerca do contexto discutido nesta dissertação. Mesmo assim, parece importante já adiantar que uma definição das implicações de um remetimento que espera como resposta esta referência do discurso do jurídico mereceria desenvolvimento mais consistente. Esta presente pesquisa procura apenas contribuir com o entendimento deste outro campo, da Justiça Criminal, no qual parece caber algo da Psicanálise, que por suas dessemelhanças parece ainda um pouco carente (em comparação) de mais pesquisas.

A presença da Psicanálise na área da Saúde não parece passível de ser questionada. Como vimos, no começo de uma análise há um pedido de cura (erradicação, supressão ou melhoria) de um sintoma. Num nível consciente se espera de um atendimento psicanalítico um tratamento análogo ao médico, ou seja, que tal sintoma tenha como condição estatutária ser extrínseco ao sujeito em questão, podendo ser portanto retirado ou suprimido.

Um analista, no entanto, não deve responder a este tipo de demanda, mas sustentar uma posição tal que a questão em jogo aponte para a sua constituição no campo do Outro, ou seja, implicando necessariamente o sujeito e suas escolhas, o que abre o campo de trabalho com a questão do desejo e, portanto, diferencia os modelos analítico e médico. Podemos dizer que uma demanda explicitamente consciente por cura representa (ou traz articulada consigo) uma demanda inconsciente de tentar "por em pratos limpos" essa relação entre o sujeito e seu objeto que se engendra no campo do Outro. É a essa demanda inconsciente que se faz escuta. De uma suposição de um saber médico o analisante passa a supor um saber sobre o desejo.

No contexto aqui discutido há um endereçamento para a Justiça, porém, diversamente da clínica psicanalítica tradicional, é difícil a cura de um sintoma aparecer como tema principal: são outras as expectativas explicitas em jogo. No entano, em alguns casos os usuários afirmam que não superarão determinado quadro depressivo, de pânico, insônia, frigidez sexual etc. "se a Justiça não resolver essa situação...". Parece haver espaço para alguma confusão aí, como por exemplo sentir-se tentado a acolher um pedido de cura de um 
desses sintomas acima descritos. Mas é preciso afirmar que o pedido explícito neste caso é pelo "funcionamento" da Justiça, mesmo que tal "funcionamento" esperado se articule à realização de uma fantasia, que para tal coloca a Justiça no lugar de um Outro aparentemente poderoso. É fato também que quando da determinação judicial, que como se diz no Fórum "tem a força de lei", a Justiça realmente se realiza com potência. A expectativa de um discurso jurídico e de uma determinação judicial aponta assim para uma particularidade deste contexto. Mas que sutilezas à escuta pode se esperar por conta dessa particularidade?

O pedido, ou medo, pelo/de funcionamento, ou não funcionamento, da Justiça aparece na maioria esmagadora dos casos. Geralmente articula-a à melhoria de algum problema relacional, a um sintoma ou à elaboração de um trauma ou luto. Desta forma, temos que um pedido justificável seria por um tratamento que pudesse dar conta de uma questão que, do ponto de vista do usuário, impediria ou dificultaria a realização daquilo que é sua responsabilidade na participação da realização de Justiça. Cabendo ao profissional a escolha de aceitar ou não tal pedido. Parece impossível impedir que o usuário do serviço também opere a passagem da suposição de um saber sobre o que acontecerá na Justiça para uma suposição de um saber sobre o desejo.

Mas o contexto do Fórum Criminal aparentemente incide de forma a esta passagem não se operar completamente, antes parece que os usuários sustentam as duas suposições concomitantemente. O manejo desta concomitância, que sobrepõe os papéis de psicólogo da instituição judiciária e psicanalista, é pedra angular da direção do tratamento dentro deste contexto. Assim, há que se atentar ao manejo da angústia nas constantes aproximações à divisão do sujeito no mesmo tempo em que há de manejar o encaminhamento do caso em sua relação com a Justiça. Não é fácil.

A possibilidade de apreensão desta diferença, como um assenhorear-se de seus endereçamentos, marca geralmente o ponto de entrada na saída do serviço psicológico. A 
partir desta diferenciação faz-se pertinente o encaminhamento do caso: de volta à burocracia institucional e externo, posto que quando fica a impressão de um pedido claro por um tratamento psicanalítico tradicional a única opção é o encaminhamento para a realização de tal tratamento em uma instituição com essa finalidade, ou seja, que possa dar suporte a um trabalho desses. Também nem sempre é fácil encaminhar um caso com o qual já se iniciou um percurso mas é a única solução possível. Além disso, a grande maioria dos sujeitos parece não querer realizar um trabalho de análise no Fórum Criminal: "é lugar de bandido, o povo vê a gente entrando...”, “... um lugar mais reservado...” etc.

Em um trabalho neste contexto pode também parecer pertinente colocar-se uma questão que propõe um posicionamento: Escuto agora o cidadão ou o sujeito? O que aparece na seguinte questão: ajudo concretamente o andamento do processo, a realização de Justiça, ou cuido do tratamento deste sujeito? Falsas questões que podem incidir como pressão sobre o profissional, afinal: de quem é a responsabilidade pelo andamento do processo? Seria do psicólogo-psicanalista a responsabilidade pelo andamento do processo? Essa escolha por cidadão ou sujeito parece também estabelecer uma separação segura que, no entanto, não se sustenta quando de uma aproximação. Haveria como na prática separar com exclusividade sujeito e cidadão, à maneira de um debate teórico? Enfim, pode a consciência se separar/desarticular do inconsciente? A resposta para todas essas questões é não, o que não desemplica o psicólogo-psicanalista de abordá-las em seu cotidiano.

Uma antinomia cidadão-sujeito pode se prestar à função de polarizar a circulação pelo social, no sentido de des-responsabilizar a articulação cidadão/sujeito em uma de suas tendências, aquela que os dirige à política: se vou pelo desejo finjo que não vejo a lei, se vou pela lei finjo que não existe o desejo, me faço objeto ou mercadoria (fetiche). A operação em questão é uma denegação da articulação irredutível entre desejo e lei, pois em ambos os casos 
tais referências encontram-se articuladas e operantes. Lacan, em seu seminário sobre a angústia, propõe que desejo e lei são correlatos.

O que se apresenta como escolha entre uma ou outra referência, pode afinal encontrar resposta em outra escolha: a escolha ética de sustentar uma posição frente aos discursos (incluindo aí as atuações) que lhe são remetidos. O caminho neste caso é oferecer um espaço no qual aquilo que está sendo remetido possa circular de forma a propiciar um espaço de responsabilização. Por exemplo: devolver para o usuário, com um "vejo que você pede isso da instituição, o que pode ser remetido a... mas parece que no mesmo tempo você...”.

Desde esta primeira aproximação ao discurso do usuário (e/ou da família usuária) fica portanto perceptível que um dos motes do trabalho diz respeito ao encontro do cidadão com a instituição judiciária. Tal encontro é portanto, sem sombra de dúvidas, tema fundamental dos atendimentos. Vale atentar, retomando o caso de Arlete, para a insistência da temática da prisão do marido, apesar de o psicólogo ter afirmado em dado momento que os fatos de que se tratava o procedimento judicial referente ao TCO, e que deu motivo ao convite para essa entrevista no Setor de Psicologia, ser sobre outro ocorrido, anterior, o de ela ter se queixado de ser ameaçada pelo marido.

Em um caso como este é provável a existência de outro processo correndo em alguma Vara Criminal sobre a denúncia de tentativa de estupro da filha, que resultou na prisão de seu marido. Este caso também ilustra, o surgimento de um tipo de endereçamento bastante comum ao início do trabalho já mencionado: o entendimento da Justiça como instituição total consistentemente articulada! Ou seja, como um Outro absoluto. Porém, quando de uma aproximação, podemos ver que na grande maioria dos casos se espera deste Outro algo não tão consistente/completo.

Sobre isso cabe uma impressão que sugere um valor: parece que o encontro com outras áreas é movimento profícuo para o desenvolvimento da Psicanálise, o que 
provavelmente também poderia ser estendido para outros encontros. Fica claro, ao revermos a história da Psicanálise, que os encontros com lingüística, antropologia, lógica etc propiciaram grande desenvolvimento tanto para a Psicanálise quanto para estas outras áreas. O extenuante trabalho de aproximação, mistura, distanciamento e diferenciação, em muitas idas e vindas sobre diversos pontos, construiu maior precisão à própria técnica. Mas o que os encontros com a Justiça podem agregar ao desenvolvimento da Psicanálise? Deixo tal questão em aberto, na expectativa de desenvolvê-la posteriormente, em outra pesquisa. 


\section{CASO 4}

Algo que, pelos motivos discutidos acima, também se repete em grande parte dos casos, é o psicólogo-psicanalista ser entendido como um mediador deste encontro com a instituição. Foi possível observar que tal entendimento opera de diferentes maneiras, não exclusivas entre si: como resistência ao trabalho psicológico, como recurso facilitador para o exercício da cidadania e como resposta à demanda de inserção de um mediador simbólico/concreto na dinâmica familiar (em muitos casos podemos entender a busca por Justiça também como um convite a um interventor, um terceiro, concreto). Mas a decisão entre responder a esta demanda, e como fazê-lo, ou seu rechaço depende de dados particulares a cada caso.

Quanto a essas expectativas dirigidas à Justiça como instituição total aparentemente consistente cabe reconhecer que algo do que estaria previsto para ser trabalhado preferencialmente durante os atendimentos já aportava com alguma insistência desde o primeiro encontro. Como exemplo temos as discussões sobre a possibilidade de recontratação de visitas e pensões para filhos (no início do trabalho geralmente são dirigidas apenas discursos queixosos sobre problemas relacionados a estas temáticas) em casos de excasais, que aparecem como o "verdadeiro motivo" dos conflitos na fala dos usuários. Frente a estas insistências, que operam muitas vezes também no sentido da resistência (não só ao trabalho analítico proposto, mas também ao exercício da cidadania em questão na Justiça), um caminho para alguns casos é propor uma retomada dos motivos pelos quais foi buscada a Justiça quando da decisão de realizar a queixa que deu origem ao TCO.

O pedido mais comum, em casos de casais em situação de conflito, que chega à instituição é a expectativa de que a Justiça determine qual dos dois está certo sobre algo (leiase: sobre tudo!). Fica perceptível que partimos de um pedido enquadrado em uma lógica na 
qual duas posições antagônicas batalham por legitimação, autorização e/ou confirmação. O convite a este terceiro parece mais um convite a dizer quem ganhou e quem perdeu. São sustentadas posições tão radicalmente exclusivas que pela via da compreensão cairíamos no seguinte problema: a realização da proposta de um implica necessariamente na erradicação/submissão total da proposta do outro. Mas como se posicionar frente a esta configuração, que parece um tanto paranóica, antinômica?

Ao encontrar tais configurações de discurso cabe atentar para o que se articula para além da significação proposta, ou seja, às relações simbólicas e às tentativas de inserção/inscrição dessas singularidades. O pedido por uma terceira presença em si já não é a afirmação de uma tentativa de estruturação simbólica? Tais insistências, portanto, podem agregar o valor de um primeiro movimento de constituição de uma demanda, como no caso relatado a seguir:

Hilda chegou sozinha à primeira entrevista de triagem, tinha 27 anos. Centrou seu discurso no relacionamento que teve com João, 28 anos, ex-marido, contra quem prestara a queixa que deu origem ao procedimento judicial.

“... nosso casamento foi um grande erro... foi uma fuga... morei um ano junto com ele e os pais dele e aí construímos nossas coisas... engravidei e entrei em depressão... fiz terapia por dois anos porque eu comecei a rejeitar minha filha... não levei alta, parei...”.

“... perdi minha mãe muito cedo... ele achava que tudo ele podia fazer porque não tinha ninguém para me proteger... fui para um albergue um dia para tentar... eu queria um marido que ficasse comigo... cobrava dele que cuidasse da filha... fica dizendo que fui morar com meu patrão... 'você só pode porque deu pro patrão'...”.

“... ele foi um pai nota mil... cuidou da menina quando entrei em depressão... não me respeitava quando eu não queria sexo... mas enquanto marido eu não posso falar isso... a menina ele vê quando está calmo, que eu deixo... se a gente voltasse...”. 
Suas posições em relação ao marido pareciam atualizar diversas ambigüidades. O que queria esta mulher da Justiça? Decidimos continuar na outra semana e deixamos combinado contato telefônico para determinar a hora. Quando nos despedíamos, já com a porta aberta, chegou João. Ela foi de cabeça baixa e não se cumprimentaram. Ele ficou na sala de espera, havia disponibilidade de agenda para a realização de mais uma triagem naquela tarde. Ao entrar na sala João afirmou não ter nada para dizer, após a proposta de contar o que houvera disse, entre outras coisas:

“... foi o patrão dela, um senhor de idade, que levou a chegar nesse ponto... ela ficou 24 horas por dia na casa dele... cheguei até a falar com ele... gostava dela bastante... procurava ela bastante... algumas vezes calmo, outras nervoso... quando comecei a ter problema financeiro que ela começou a desaparecer...”.

Geralmente a primeira entrevista com alguém que está sob acusação é diferente da com um demandante. Aparece muita resistência em falar e muitos não aderem ao serviço. Alguns dizem não se sentir confortáveis para falar neste ambiente em que são acusados de algo que não fizeram (ao menos é o que dizem na primeira entrevista). No entanto geralmente produzem um discurso de queixas, o que vemos também neste caso. A maioria se apresenta bastante preocupada com os rumos que o procedimento judicial pode tomar, com as possíveis conseqüências penais, posto que geralmente cada qual sabe do que está sendo acusado.

Como Hilda e João haviam concordado, separadamente, em realizar uma entrevista conjunta agendamos para a semana seguinte. Ambos vieram na hora. Restaram poucas anotações do discurso concreto produzido nesta sessão. Algumas vezes em uma sessão com um casal (e também com famílias ou grupos) o ritmo e a quantidade de falas podem acabar dificultando a tarefa de anotação. A opção sempre foi privilegiar a condução do trabalho junto aos usuários em detrimento da pesquisa. O material apresentado a seguir segue de maneira fiel 
boa parte das anotações (excetuando-se o que poderia servir à identificação das pessoas envolvidas). Abaixo o resumo das anotações do atendimento:

Durante toda a sessão trocaram inúmeras acusações. Ele começou reclamando dela impedi-lo de ver a filha. Ela respondeu apontando uma série de negligências dele no cuidado da filha. Ele retrucou apontando também uma série de negligências dela em relação à filha. Ela o acusava de 'esquecer a filha', de deixar a menina 'com qualquer um, até com a nova namorada', falou mal dessa 'nova mulher' e de 'falar mal de mim pra menina', 'falar que eu não presto'. Ele a acusou de 'jogar a menina contra' ele, de impedir ele de ver a menina 'pra se vingar de mim porque arranjei uma nova namorada' e de usar o dinheiro da pensão 'pra comprar coisas pra ela mesma, cosmético e roupa', defendeu sua atual companheira e comparou-a ao senhor que ele afirma que 'é um velho tarado que não presta' 'me ameaçou porque trabalha [em instituição de segurança pública]'. Ela disse que não tem nada com esse homem, só aluga um apartamento dele. Foram feitas duas intervenções pelo aumento de volume das falas, ambos baixaram o volume; depois foi apontado que um começava a retrucar enquanto o outro ainda falava, ela parou, ele diminuiu. Ficou a sensação de que ela parece ainda ter esperança de voltarem. Narraram diversas brigas no momento de entrega da criança. Parece que querem trazer a briga para os atendimentos. Focam todo o conflito na figura da menina. Foi perguntado a eles como será que a menina estava lidando com isso. Apresentaram preocupação e culpa. A menina tem quatro anos. No que diz respeito ao diagnóstico diferencial, aparentemente ambos parecem propor um sintoma neurótico. Foi combinado de continuar outro dia, disseram que vêm. Saíram conversando.

O questionamento sobre como se sentia a filha parece ter trazido à tona a dimensão de que tal filha também é sujeito, mas como isso se manifestaria nesta dinâmica, no dia-a-dia? O conflito atuado poderia prescindir da figura da filha? Estariam dispostos a remeter tal conflito para um trabalho psicológico? Já poderiam esses usuários se responsabilizar por isso? As 
reações de culpa e preocupação, as ambigüidades e as provocações pareciam confirmar o diagnóstico de neurose. Muitas questões sobre a direção de um trabalho emergem após um atendimento.

A segunda entrevista conjunta começou com atraso de cinco minutos, ele atrasou, mas tomou a palavra no início:

João: "Ela me deixou ver a menina nesse fim de semana, foi ótimo que não brigamos...".

Hilda: “Mas você atrasou de novo... não dá pra confiar nele... sempre atrasa... parece que tenho que ta ali à disposição dele... já esqueceu de pegar ela várias vezes... só quer saber dele mesmo...".

João: “... você passa por mim e finge que não conhece... me esnoba... teve uma vez que ela deixou minha filha sem roupa pra trocar no fim-de-semana... tive que sair pra comprar roupa pra ela".

Hilda: “Só assim pra você comprar alguma coisa pra ela mesmo... passa o fim-desemana sem dar banho na menina... dá só porcaria pra ela comer...”.

João: "Não mesmo, na minha casa sempre tem comida boa porque a [nova companheira] é ótima cozinheira, diferente de você que quando casou comigo...".

Falar da nova companheira aumentou a irritação de Hilda, voltaram a trocar acusações de negligência sobre a criança, desde esquecê-la no meio de uma feira pública até deixá-la sem casaco numa tarde fria. O psicólogo-psicanalista apontou que determinadas falas pareciam provocação, a resposta foi uma negativa, mas esta fala teve como efeito colateral esfriar um pouco a briga, tom e ritmo se atenuaram. Porém, poucos minutos depois, vinham à tona novas temáticas claramente provocativas. Ambos assumiram novamente um lugar de buscar provar que o outro não tinha condições de cuidar da criança, várias falas como: “Ele(a) não tem a menor condição de cuidar da criança". A cada fala destas uma questão era dirigida 
ao profissional: "Você entende que...?". Ambos pareciam ter entrado em uma disputa por um mesmo objeto. Uma intervenção:

“Acho que na verdade não estou entendendo nenhum dos dois. Se for levar ao pé da letra o que vocês estão dizendo o que entendi até agora é que nenhum de vocês tem a menor condição de cuidar dessa criança, é isso? Então vocês dois concordam que essa criança não devia ficar com nenhum dos dois?".

A resposta foi um silêncio, não muito longo, com algumas lágrimas de Hilda.

Uma intervenção que devolve aos falantes aquilo que falaram é lugar comum na prática de um clínico. Este tipo de intervenção opera como uma insistência do profissional para que o sujeito escute o que fala, que os significantes apresentados circulem um pouco mais nesse espaço, no sentido de possibilitar/provocar que se responsabilize por sua própria produção significante.

Porém, no contexto da Justiça, as coisas se complicam um pouco. Como vimos, a Justiça opera determinando e isso não é um detalhe. O psicólogo-psicanalista é visto como parte da instituição Justiça, pois, como discutido anteriormente, seria impossível pensar que um trabalho neste contexto estivesse completamente desarticulado do funcionamento institucional. Ao mesmo tempo, a Justiça pode e deve determinar a retirada de uma criança de um lar no qual não venham sendo resguardados os pressupostos do ECA (Estatuto da Criança e do Adolescente). A fala do psicólogo-psicanalista soara, juntamente e para além de seu efeito tradicional, como uma ameaça de tirar a criança desse lugar assumidamente tão conflituoso? Tal intervenção teria chamado para uma responsabilização os cidadãos, além dos sujeitos?

João: “Não é nada disso, ela é ótima mãe... é que ela fica me provocando...".

Hilda: "Ele também é bom pai, mas a gente briga muito... eu provoco ele as vezes, mas ele também me provoca... só queira que a gente parasse de brigar...". 
"Então vocês estão me dizendo que ficam se provocando e brigando e que a menina serve de desculpa pra essa briga toda? E também que ficam colocando ela no meio dessa briga que talvez ela nem consiga entender?”.

Novamente a sobreposição chama atenção: o convite a re-inserir a criança como sujeito nesta dinâmica não convocaria para uma dupla responsabilização? Não seria ao mesmo tempo um convite para inserir um cidadão de direitos (criança)?

A fim de entender a fundamentação teórica dessas duas intervenções podemos retomar o conceito de retificação subjetiva. Lacan, propôs que no momento das entrevistas preliminares um psicanalista possa intervir, em um sentido aparentemente contrário daquilo que será sua posição ética no decorrer do tratamento, realizando uma interpretação que proponha um "primeiro discernimento de sua posição no real”. Apesar da aparência há que atentar para o fato de que a retificação subjetiva não propõe algo da ordem de uma adaptação à realidade, mas aponta para a responsabilidade do paciente na criação (e/ou manutenção) desta realidade da qual se queixa. Quinet (1994) propõe que na retificação subjetiva "trata-se de introduzir o sujeito em sua responsabilidade [...]. A retificação subjetiva aponta que, lá onde o sujeito não pensa, ele escolhe; lá onde pensa, é determinado, introduzindo o sujeito na dimensão do Outro". O que nos possibilita entender a pertinência desta intervenção quando do diagnóstico de neurose.

Voltando ao caso, após a intervenção emergiram primeiramente algumas autorecriminações e depois foram dirigidas algumas perguntas sobre a possibilidade da filha ter ficado traumatizada e se fosse o caso se haveria cura. Nestes dois movimentos agiram conjuntamente, um completando a idéia do outro, parecia que haviam deixado as posições polarizadas para assumirem uma postura solidária. Ainda neste momento solidário Hilda propôs uma questão: “Porque será que a gente tá fazendo isso? A gente se dava tão bem...”. E rapidamente após enunciar esta questão dirigiu uma pergunta: "Vocês aqui ajudam as pessoas 
a resolver esse tipo de problema?". A partir destes posicionamentos foi, então, contratado um trabalho junto ao Setor de Psicologia.

Quando da contratação de um trabalho junto ao Setor de Psicologia, ficou pré-definido o seguinte: realizaríamos alguns atendimentos individuais com cada um em separado, pois: cada qual demonstrava querer entender qual a sua participação no conflito e o que poderia fazer para transforma-lo de forma a "proteger" a si mesmos e a menina; ambos achavam que seria "dificil" trabalharem juntos pois haveria "muita discussão" e que aproveitariam melhor o trabalho individualmente; e Hilda tinha dúvidas se queria manter ou não a representação e gostaria de um espaço "só seu” para discutir esse assunto. O serviço contratado visaria: o atravessamento do ciclo repetitivo de conflitos estruturados entre as partes; algo da ordem de uma orientação aos pais separados quanto à criação da filha; e a tomada de decisão de Hilda sobre o andamento do processo. Também ficou contratado que nestes atendimentos avaliaríamos a viabilidade de voltarmos a um dispositivo conjunto mais à frente.

Foram realizados ao todo treze atendimentos após as triagens: num primeiro momento três com Hilda e três com João e depois seis com ambos, com um atendimento individual para João entre a quarta e a quinta sessão conjunta. O período compreendido para a realização destes atendimentos foi de três meses e meio. Grande parte do percurso destes usuários será apresentado de forma descritiva, aos moldes de um resumo, por conta do extenso volume de material transcrito e anotações fruto destes atendimentos.

Alguns dados possibilitam uma visão mais geral da relação pregressa com a Justiça. Estavam separados judicialmente havia um ano, a guarda da filha estava sob responsabilidade da mãe e estavam estipulados o modelo de visitas e o pagamento de pensão. O caso foi encaminhado pelo Ministério Público.

Em atendimentos a casais separados é comum que em sessões individuais os usuários se ponham a narrar a história do relacionamento. Neste caso ambos tomaram este caminho. 
Hilda narrou parte do que entende ser sua história de vida: fora abandonada pela mãe aos quatro anos e criada por tios, até que conheceu João aos dezessete anos e teve início um relacionamento amoroso. Foi então morar na casa da família dele por um ano e logo depois se casaram. Considerava-se muito dependente de João quando jovem, no sentido emocional, e colocara-o como sua única referência de vida, no relacionamento do casal havia como um contrato não-dito de que ele deveria cuidar dela.

Após este trabalho de recuperação de sua história de vida, Hilda começou a se questionar sobre a pertinência do procedimento judicial. Em dado momento deste questionamento deu-se conta que seu movimento na Justiça visava algo da ordem de uma vingança, e não pelos fatos descritos no B.O., mas pela falha de João como cuidador, pela subseqüente separação e pelo que sentia como um abandono da filha. Disse sobre esses assuntos coisas como: "to péssima com tudo isso, ele é ótimo pai, a [menina] é tudo pra ele na vida", "ele não agüentou a perda do irmão e eu não soube ficar do lado dele..." e "acabou mesmo, é uma pena... sempre achei que ia ser pra sempre".

João, de sua história contou o seguinte: foi um rapaz criado por um pai alcoolista juntamente com um irmão, mais velho que ele, e tinha este irmão como principal referência, uma vez que "pouco" pode contar com o pai. Sofrera diversas agressões físicas deste pai, o que o levou a se distanciar dele, e na atualidade nem saber de seu paradeiro. Ocorreu que este irmão de João faleceu. Afirmou que neste momento ela fazia de tudo para que ele se sentisse "impotente", e que era a verdade pois não conseguiu cuidar de sua mulher "por algum tempo", uma vez que se sentia "perdido". Como efeito sentiu um distanciamento cada vez maior de Hilda ("ela nunca estava lá") que levou às brigas e a separação. Passou de uma posição de acusá-la de traição para a fala de que "foi tudo minha culpa", sobre um movimento que chamou de "abandonei ela". 
Nestes encontros individuais em nenhum momento apareceu o tema da orientação acerca da criação da filha. Porém, pelo que narraram, a filha fora retirada da arena do conflito. Mais, as brigas deixaram de acontecer naquele mês. Uma suposição possível é que cada qual estava começando a se responsabilizar por seus próprios conflitos, no sentido de que os conflitos com o outro pareciam inegavelmente articulados a questões pessoais pendentes. Há que considerar também a possibilidade de haver algum temor em relatar tais atuações ao “psicólogo da Justiça”.

$\mathrm{Na}$ volta ao dispositivo de atendimento conjunto algumas surpresas. De início pareciam colaborar um com o outro, com afirmações que enalteciam uma situação melhor consolidada:

Hilda - "Está tudo bem, melhorou muito".

Após alguns minutos, no entanto, a situação mudou:

João - “Aprendi a respeitar o espaço dela, ligações não tenho feito mais... evito ficar perturbando... nós estando longe é melhor, muito melhor... eu não aceito a opinião dela e ela não aceita a minha... mas a gente é obrigado a ter contato por causa da nossa filha".

As falas de João provocaram uma reação imediata em Hilda:

Hilda - "Eu acho que a minha filha é muito esperta, ela percebe todas as conversas que estão sendo ditas...”.

João - "Eu também acho ela esperta... o suficiente pra saber que o que você fala da [nova companheira] é um monte de besteira, porque a [menina] adora ela...".

Neste ponto começaram a se atropelar em diversas acusações que retomavam as temáticas das entrevistas de triagem. A função da "denúncia" no atendimento a casais (neste caso um ex-casal) aparecia constantemente nestes atendimentos. Nesta hora, o caminho foi sustentar o tema em questão como algo que incomoda/afeta a ambos e não como um modelo 
em que um denuncia o outro. É interessante notar que ambos produziam frente a este posicionamento:

João - "Acho que os problemas dela começaram faz tempo... ela morava com o irmão e com a esposa dele... essa mulher ficava infernizando a vida dela... perdeu a mãe cedo, com oito anos... o pai dela bebia e ela morria de medo dele".

Hilda - "Minha mãe fugiu de casa quando eu tinha quatro anos... meu pai batia nela... chegava em casa bêbado... nessa hora eu falava: 'não vou passar pelo que minha mãe passou'... sai da casa e fui morar com meus tios... minha mãe morreu e fui morar com meu irmão...".

$\mathrm{Na}$ sessão seguinte começaram narrando um briga que tiveram durante a semana quando da entrega da filha para João:

João - "Ela atrasou de novo... é isso, não adianta ficar aqui conversando e aí ela vai e...".

Hilda - “Eu esperei pra falar pra você aqui porque você tava muito nervoso... eu atrasei porque... foi difícil para toda a família... [nome] que era o irmão dele era como um pai pra ele... tava desempregado e dava ouvido pra todo mundo...”.

João - "Nessa época eu ia fazer uma operação quase certa... 99\% de chance de dar certo...".

Mal Hilda começara a falar da morte do irmão de João e ele mudou repentinamente de assunto. Hilda aceitou a mudança de tema. A morte do irmão de João foi o principal tema da sessão seguinte. Demonstrou muita tristeza em rever tal tema, a ponto de pedir um atendimento individual para falar da temática, que ainda via como muito difícil.

Com a realização do trabalho começaram a se haver com sua situação, pelo que produziram de entendimento, Hilda e João mantinham uma forte ligação com muitas questões comuns em aberto, apesar de separados de corpos e judicialmente. Estas questões remetiam à 
constituição e percurso de vida de cada um deles, mas houve como que uma fixação que operava de forma que tais questões eram atualizadas quando dos encontros e desencontros entre ambos. Aparentemente a responsabilização de cada qual por estas questões foi operando uma separação simbólica entre ambos e a criança foi tirada do campo do conflito.

Somente neste momento do trabalho voltaram a se questionar sobre o percurso que estabeleciam na Justiça. Foi trabalhada a questão da pertinência das demandas em relação ao Judiciário. Hilda abriu mão das vontades de vingança e reaproximação a João, mas manteve a representação "por via das dúvidas... para ver se as coisas mudaram mesmo...".

Neste ponto o caso foi encaminhado de volta ao cartório para ser realizada a audiência preliminar. O caso também foi encaminhado para a rede, uma vez que Hilda achava que ainda sobravam pendentes assuntos de sua infância que gostaria de tratar em uma terapia. No dia da audiência preliminar Hilda passou para "dar um alô" e dizer o quanto as coisas estavam melhor e também para comunicar que estava decidida a renunciar ao direito de representação uma vez que entendia que neste caso ambos eram responsáveis pelos fatos acontecidos.

Um último ponto a ser levantado quanto ao dispositivo diz respeito ao encaminhamento. Havia dois momentos "chave" para a realização dos encaminhamentos: ao final da triagem e no fim do trabalho dos atendimentos. Na triagem, o encaminhamento de um caso tem três possibilidades: interno, para o serviço de atendimento do Setor de Psicologia ou para Mediação; externo, para o(s) serviço(s) adequado(s) à demanda do usuário; e encerramento, nas vezes em que o trabalho realizado na triagem já trazia um resultado que era entendido como suficiente pelos usuários. Além disso, havia casos que não compareciam ou que compareciam e não se interessavam pelo serviço oferecido.

Os encaminhamentos internos, como já foi dito, dependiam da possibilidade de articulação entre a demanda para um trabalho psicológico e a passagem pela Justiça. Os 
encaminhamentos externos eram o recurso para casos que: ao portar um pedido por serviço psicológico afirmassem não querer, ou não poder, realizar o trabalho no Setor de Psicologia, por ser em um Fórum Criminal, por indisponibilidade de horários ou transporte, por preferir se tratar no particular etc; ou aos que entendiam que as questões suscitadas devessem ser trabalhadas de forma desarticulada ao percurso no Judiciário.

Quanto ao encerramento são principalmente dois tipos de casos: há os casos que diziam que "o serviço não está ajudando em nada", posto que algumas expectativas objetivas não eram respondidas, e que eram encerrados por desinteresse; e há aqueles em que a abertura de um espaço no qual se podia realizar uma primeira reflexão era o suficiente para que tais usuários se posicionassem de forma a querer resolver seus conflitos sem a presença da Justiça como intermediador ou esperando da Justiça apenas o que lhe é constitucionalmente cabível, o que implicava remeter outras questões para contextos mais pertinentes. Em alguns destes casos o encerramento e o encaminhamento externo eram realizados conjuntamente. 


\section{CASO 5}

Quanto ao encaminhamento interno cabe atentar a um limite, sobre o que pode/cabe ser escutado pelo profissional. Há que diferenciar a proposição de um trabalho de construção de um saber e/ou transformação de uma situação (um espaço de escuta e intervenção), como o aqui proposto, de o oferecimento de um espaço no qual tudo pode ser dito, ou seja, um espaço para se "vomitar" aquilo com o que não se sabe bem o que fazer a fim de se desresponsabilizar, um espaço de mostração (e repetição) do horror, um espaço de negação pela realização da vontade de causar angústia no profissional, um espaço de puro gozo. Essas possibilidades também devem ser barradas pelo profissional.

Ainda sobre o encaminhamento interno uma restrição: há que se atentar nesse contexto para a possibilidade de proposição perversa de adesão ao serviço por um interesse outro. Nestes casos não aparece a busca por um serviço psicológico, mas sim o interesse: na procrastinação do andamento do processo criminal; no uso do espaço para obtenção de vantagens pessoais (bens, dinheiro etc); no uso do espaço como "prova" de que sofreu um trauma psíquico (geralmente com finalidade indenizatória); em vingança (no sentido de ser um espaço para obtenção de informações do ex-cônjuge); na tentativa de "consertar o outro"; e no uso do espaço apenas como forma de se reaproximar do ex-cônjuge. A postura assumida frente a tais interesses, até agora, é que devem ser claramente barrados. Entre estes, o interesse mais recorrente é: vingança.

O caso apresentado a seguir deixou questões sobre que uso se pretendia fazer do serviço oferecido:

Fernanda chegou encaminhada pelos funcionários do cartório em 2004, a audiência havia sido cancelada, mas um dos funcionários que fazem a recepção das partes e seus advogados procurou o psicólogo-psicanalista com a seguinte questão: "ela não tá bem, você 
não quer ver se pode ajudá-la?". Como havia disponibilidade ainda naquela tarde foi pedido que Fernanda aguardasse na sala de espera.

Ao entrar na sala de atendimento logo se sentou e esperou. Sua fisionomia era bastante sofrida, estava suja e com os cabelos desgrenhados, aparentemente uma mendiga. Após as apresentações, o psicólogo-psicanalista explicou um pouco o que era o Setor de Psicologia e perguntou se ela precisava de alguma ajuda. Em alguns casos podemos começar falando até que a pessoa reconheça algo que a faça endereçar uma primeira fala.

“To aqui porque meu ex-marido me agrediu... muitas vezes... separou há mais de um ano mas ainda fica no meu pé... não trabalho, sobrevivo de cesta que consigo na Igreja $[\mathrm{X}]$... to assim toda largada mas não sou de rua não, moro num apartamento meu... é que já faz três anos que não consigo me cuidar, nem banho eu tomo... olha que situação a minha... tudo porque ele me humilhava... nunca me respeitou... sou formada em [profissão] e fiz uma especialização em $[\mathrm{X}]$... trabalhava no Hospital $[\mathrm{X}]$ e era amiga de todo mundo lá... se você perguntar eles confirmam tudo pra você... era muito esforçada... plantão... até consegui comprar um apartamento meu... pequeno mas meu... agora largada... um horror... hoje nem vinha, mas a vizinha disse que a Justiça... pelo menos quando ele morava comigo eu tinha que me arrumar um pouco mais...”.

O psicólogo-psicanalista realizou uma fala que articulava os dados trazidos até então de cuidado de si, respeito, percurso dela (estudos e trabalho) e a situação atual à época, na qual ela parecia repetir algo de um desrespeito para consigo mesma, mesmo após a saída de seu ex-cônjuge, tal fala foi seguida de algo como: O quê você está fazendo da sua vida Fernanda?

“Aí! Não sei doutor, aquele homem mexeu com a minha cabeça, gostava muito dele, me entreguei de corpo e alma... ai me bateu e parece que tudo na vida perdeu o sentido... não posso mais ficar assim... quem vai querer ficar perto de alguém com esse cabelo?”. 
A primeira impressão foi de uso dos recursos simbólicos referidos à norma fálica, parecia supor a circulação de um saber sobre o que deveria se feito para mudar a situação, por isso uma primeira hipótese diagnóstica de neurose, enquanto as temáticas de impotência e insatisfação apontavam para um tipo histérico.

A fala do psicólogo-psicanalista parecera operar como retificação subjetiva. Faltou no retorno na semana seguinte, não ligou. Após três semanas apareceu, chegou vestida impecavelmente, com o cabelo arrumado, contando que não poderia vir mais porque arranjara um emprego de vinte horas semanais numa clínica particular e mais: ia fazer uma entrevista para um segundo emprego também de vinte horas no dia seguinte. A conversa, informal (estávamos de pé no corredor), durou algo em torno de dez minutos, na qual agradeceu efusivamente diversas vezes, afirmando-se em "divida pro resto da vida com você". Ligou alguns dias depois para informar que conseguira o outro emprego e agradecer novamente, disse ainda que dali a quarenta dias haveria a audiência remarcada e que passaria "para dar um alô". Essa mudança tão radical assustou, afinal o que teria causado esse efeito? Também a primeira idéia de diagnóstico de neurose foi questionada. Aquilo que na hora parecera ter operado como retificação, agora se apresentava como que um passe de mágica. Como interpretar o ocorrido afinal?

Uma semana antes da data da audiência ligou. Chorava soluçando, disse que seu exmarido havia arrombado a porta de sua casa e a violentado sexualmente havia quinze minutos, achava que ele ficou descontrolado ao receber a convocação para a audiência. Narrou o episódio, o que teve um efeito aparente de acalmá-la. Pediu então que eu ordenasse a polícia a prendê-lo, diante da resposta da impossibilidade daquela proposição se retratou e perguntou o que tinha que fazer para "vê-lo atrás das grades?". Foi informada do procedimento para este tipo de caso, mas então ficou novamente ansiosa e disse: 
"não posso fazer isso, to suja, preciso me lavar, não to mais agüentando o cheiro dele em mim... me sinto suja por dentro... to com nojo de mim mesma... posso ir mais cedo pra conversar com você no dia da audiência?... preciso desligar, vou tomar banho..."

No dia da audiência chegou à porta e perguntou:

"Ele também está aí, será que posso convidar ele pra conversar com você também, nós três?".

"Sim, se ele concordar".

O que rapidamente demonstrou ser um equívoco do psicólogo-psicanalista. Logo após entrarem na sala, Fernanda começou a "disparar" contra o ex-marido sendo extremamente agressiva e ameaçando-o com a Justiça, chegou até a criticar o intumescimento de seu pênis! O psicólogo-psicanalista interrompeu: "Fernanda, você pode me dizer porque queria uma entrevista conjunta com $[\mathrm{X}]$ ?" Pergunta tardia, deveria ter sido feita quando da proposição da entrevista a três, antes da aceitação da proposta. A proposta pareceu viável, posto que diariamente atendia casais em conflito, mas provavelmente confiou em sua imaginação de que conseguiria conduzir o caso, péssima idéia. Esqueceu de tomar algumas precauções costumeiras, como entender minimamente os motivos de cada uma na participação da dinâmica, uma hipótese diagnóstica confiável, o momento que cada um atravessava, as possíveis "pressões" da proximidade da audiência por vir etc. "Pra ele saber que agora vai pagar por tudo", respondeu Fernanda, e recomeçou a atacá-lo verbalmente. O homem só olhava pra baixo, sem nada falar. O psicólogo-psicanalista falou de novo:

“Fernanda essa é uma casa de Justiça, não de vingança. Acho que deve ser justo você sentir raiva e que tem todos os motivos para atacá-lo, mas dentro dessa sala as coisas não podem caminhar nessa direção”.

“Quer dizer que você vai ficar do lado dele, apoiando esse estuprador? Não posso acreditar, você que era meu salvador...”. 
“Aqui não se trata de estar do lado de alguém. Estou para ajudar, mas nunca para a realização de uma vingança pessoal, só posso te ajudar como psicólogo ou no seu acesso à Justiça".

“Então não sei mais o que to fazendo aqui, se é pra ver você se bandear pro lado dele... prefiro ir embora a ter que ver isso...".

E foi embora mesmo, nunca mais procurou o serviço. Apesar do evidente descuido, parece possível extrair algum entendimento, questão ou valor da experiência. Em primeiro lugar: nunca aceitar uma proposta (contrato) de trabalho sem dar ao contratante o trabalho de explicar o que quer ou o por quê desta proposta. Do ponto de vista do lugar proposto ao psicólogo-psicanalista pudemos acompanhar uma virada compreendida entre a ocupação de um lugar que realizava algo quase mágico para um lugar de falha total, de salvador a messias, sem meio termo. As hipóteses levantadas acerca deste movimento poderiam remeter a questões diagnósticas estruturais. Mas quanto a Fernanda ficou a dúvida, acho que nunca saberemos ao certo o que houve. 


\section{Encontros e desencontros dos usuários do JECRIFAM com a Justiça}

Observando o grupo de usuários do Fórum Criminal, podemos perceber que em alguns casos mais de um fator mobiliza o cidadão em seu percurso junto à Justiça. Percebemos que mesmo quando existe pertinência da queixa em relação à Justiça (quando ocorreu um fato que pode ser tipificado como crime previsto pelo Código Penal ou alguma Lei específica) foi possível observar pedidos destes cidadãos endereçados à instituição judiciária, para além da efetiva responsabilização legal cabível esperável. Vimos que em muitos casos os cidadãos esperavam da instituição judiciária também a realização de algum interesse e/ou que esta instituição se prestasse ao papel de referência para posicionamentos acerca de outras questões abertas nas relações "diretamente” implicadas aos procedimentos judiciários (processos, etc), o que nos permite situar tais pedidos como um endereçamento para além dos fatos de que trata o procedimento.

Um pedido por referência é bastante justificado, pois, como sabemos, a Justiça Criminal é um dos pilares da nossa sociedade e deve se prestar ao papel justamente de referência para um justo exercício de cidadania, quando cabível, enquanto que pedidos associados a algum interesse cívil (a se reportar ao âmbito Cívil da Justiça) ou à obtenção de referência para questões de foro íntimo (ética, moral e/ou outros) nem sempre parecem tão pertinentes. Ocorre que em alguns casos o cidadão dá maior relevância a estes outros pedidos ou questões do que à responsabilização legal do acusado, ou seja, maior importância para as respostas a estes outros do que ao andamento do processo. Em outros casos estas questões e pedidos se encontram tão condensados que o próprio cidadão tem dificuldades para entendêlos. Ou então, o sofrimento é tal pela aproximação ao trauma e/ou às marcas da violência experimentada, ao que o cidadão está invariavelmente exposto num processo no qual é parte, que pode ocorrer um efeito de distanciamento e alienação. 
Surgem, por conta desses excessos ou dificuldades de endereçamento, alguns desencontros comunicativos no percurso destes cidadãos na instituição judiciária, uma vez que há diferença entre expectativas e possibilidades do cidadão, e objetivo e burocracia do Judiciário. Muitas vezes essa diferença não ficava clara nem para os cidadãos nem para os operadores do Direito, por conta de diversos fatores, dos quais são apresentados alguns, abaixo:

- O cidadão não se encontrava com disposição para apresentar suas questões e pedidos uma vez que a reaproximação, ou rememoração, dos fatos violentos de que foi vítima, direta ou indireta, afetava-o quase que integralmente, silenciando-o;

- O cidadão encontrava-se pouco informado sobre o funcionamento da Justiça e acabava postando-se de maneira passiva diante dos procedimentos, respondendo apenas ao que lhe era diretamente perguntado, agindo de forma "mecânica", não se esforçando por fazer reconhecer seus pedidos e questões;

- O cidadão sabia de seus pedidos e questões, mas tinha dificuldade de colocá-los em palavras, por falta de recurso pessoal, por não achar adequado, por timidez ou por não enxergar espaço para tal colocação na audiência ou outro momento de encontro com os operadores do direito em questão;

- O cidadão ignorava algumas de suas questões, que atuam inconscientemente;

- O momento de audiência era investido e fantasiado de forma que alguns usuários simplesmente sentiam-se "paralisados", "confusos" ou "congelados", e acabavam por nada dizer;

- O cidadão chegava a nomear questões e pedidos, mas pareciam inadequados para o operador do direito, seja por ser de difícil compreensão ou por conter temática não diretamente ligada aos fatos em questão, o que fazia com que o operador reagisse excluindo tal demanda da cena; 
- O cidadão chegava a nomear questões e pedidos, mas pareciam inadequados para o operador do direito, por serem impossíveis em relação às possibilidades da instituição judiciária (por exemplo um pedido de atenção, carinho ou cuidado), o que fazia com que o operador também reagisse excluindo tais discursos da cena;

- O cruzamento entre a demora da burocracia e a pressa da instituição acabava causando sensação de "estar perdido" no cidadão, que se sentindo assim se desinteressava, distanciava e alienava do procedimento judiciário em andamento;

- As expectativas e conhecimentos do cidadão sobre os ritos jurídicos estavam fundamentadas em modelos midiáticos e/ou tinham por referência conversas com pessoas não tão bem informadas, sendo diferentes do funcionamento de fato da instituição judiciária. Esta diferença também pode ser causa de desencontro, se o cidadão não puder flexibilizar suas expectativas e seu olhar sobre a instituição;

- A reprodução de aspectos da relação historicamente construída entre cidadão e Estado no Brasil, com pouquíssimo diálogo, na qual muitas vezes os governantes parecem autorizados a sustentar que o aspecto decisório possa prescindir de uma responsabilização discursiva ante ao corpo civil, o que também atualizou um modelo de Estado paternalista no qual cidadão se apassiva enquanto este Estado decide os rumos a serem tomados;

Cabe um parêntese aqui sobre esta construção social histórica da relação cidadãoEstado. Um caminho de entrada para tal discussão pode usar como referência as proposições de Sérgio Buarque de Hollanda em Raízes do Brasil (1996). Nesta obra, o autor utiliza uma metodologia de apresentação de contrários para explorar conceitos polares capazes de suportar intervalos tensos propícios a uma primeira leitura sobre o campo em questão. Propõe, assim, um jogo dialético de constituição de lugares e pertinências que trata de maneira dinâmica nosso processo histórico. Parte, sob esta ótica, do modelo político trazido da Península Ibérica, que exaltava prestígio pessoal articulando-o a privilégios, para introduzir 
elementos que possibilitam reflexão sobre as formas de expressão das relações de trabalho e hierarquias. Propôs, como uma de suas teses principais, rediscutir a noção de "homem cordial" (apresentada inicialmente por Ribeiro Couto), afirmando que este "homem cordial", o brasileiro, buscaria engendrar uma "relação de simpatia", como em um modelo familiar, ao encontrar/enfrentar o Estado, fugindo das relações burocráticas impessoais (que caracterizariam esta relação com o Estado) para migrar para padrões pessoais e afetivos. Tal tentativa, mesmo quando só nas aparências, implicaria numa inadequação à possibilidade de participação nos ritos estatais, entre outros.

- O fato de durante alguns anos de regime militar, a chamada "ditadura" (mas não só), muitos crimes de Estado terem sido realizados e escamoteados pelas instituições de Segurança Pública e Justiça, o que provocou distanciamento e pouca confiança na comunicação do cidadão com as ditas instituições;

- A dificuldade do cidadão brasileiro comum em entender e se responsabilizar pelo modelo de Estado do país, a saber: de direitos e democrático. Dificuldade esta diretamente ligada às decisões políticas de direcionamento da educação formal e da precariedade dos modelos de encontro família-Estado estabelecidos;

Cabe, neste ponto, mais um parêntese. Parece de extrema relevância que se inicie uma discussão, ou amplie as aparentemente tímidas discussões já estabelecidas, a respeito das relações entre famílias e Estado, especialmente sobre o tópico da educação para os direitos ${ }^{18}$. Temos em nossa Constituição Federal o estabelecimento de algumas séries de estruturas diretamente amparadas nas relações pessoais e institucionais com leis e contratos, que fundamentam a própria noção de cidadão contratada/instituída. Ocorre que no tópico da formação deste cidadão para esse modelo contratado/instituído, as responsabilidades da educação formal e da família não encontram bordas claramente definidas. Muitas vezes

\footnotetext{
${ }^{18}$ Para uma introdução a algumas interessantes questões referentes aos problemas na educação formal, para além da relação família-Estado, indico o livro Em campo aberto (BRANDÃO, C. R., 1995).
} 
podemos perceber que, na prática, cabe ao grupo familiar a transmissão de uma série de valores fundamentais para a formação do cidadão, valores que extrapolam a formação individual atravessando o campo das relações públicas. Porém, ao lermos a carta régia podemos nos deparar com a seguinte constatação: parece não haver dispositivo instituído que ofereça suporte para as famílias nessa tarefa de transmissão. Sobre essa temática é possível propor diversas questões cuja discussão aprofundada não cabe no presente projeto, mas acho pertinente, ao menos, citar algumas: Que implicações esperar de uma responsabilização estatal sobre parte da transmissão de valores realizada nas famílias? Como garantir que tal responsabilização não levasse à promoção de modelos ditatoriais/fascistas? Será possível criar dispositivos que garantam efeito democrático em uma responsabilização dessas? Para além dessas questões acho relevante questionar também o quanto e como atualmente as famílias brasileiras se encontram representadas nos diversos pontos de encontro com o Estado. Às vezes parece que a posição mais comum deste Estado é de enfrentar tais encontros focando apenas um cidadão individualizado.

Esta individualização de direitos e responsabilidades e suas implicações nos casos de crimes de família parecem merecer algumas reflexões e cuidados. Há casos nos quais toda a família se percebe implicada na construção da cena na qual um ato violento se realiza. A passagem pela Justiça parece, assim, operar uma negação do percurso de vida deste grupo familiar, ao supor a antinomia vítima versus autor dos fatos.

- O modo de funcionar da Justiça, que muitas vezes preteriu uma leitura do contexto no qual figurassem as ambigüidades subjetivas do cidadão em prol de um funcionamento altamente burocratizado;

- As dificuldades do cidadão em entender o discurso jurídico e circular em uma instituição quase que totalmente referida a este discurso; 
Para além de ressaltar o quanto destas dificuldades é inerente à pífia formação nas matérias jurídicas, campo do Direito, do brasileiro comum, parece interessante apontar que a discussão das dificuldades decorrentes do não entendimento das práticas jurídicas e do funcionamento extremamente burocratizado são questões antigas. Já em 1530 Rabelais, em Gargântua e Pantagruel - Livro Segundo (capítulos X a XIII, 1991), denunciava jocosamente o funcionamento deste encontro entre cidadãos e Justiça da época, no qual os primeiros levavam pedidos e expectativas incabíveis à instituição enquanto que esta respondia com operações e burocracias incompreensíveis a tais cidadãos, de forma a sustentar por anos uma relação desencontrada.

- A pressa institucional atual é outro fator que tende o funcionamento do Judiciário a optar por apenas realizar a burocracia, à revelia do oferecimento de espaço para grandes debates ou reflexões junto à cidadania usuária.

A frase, lugar comum atualmente, "a Justiça está sobrecarregada" soa como jargão no dia-a-dia da instituição. A impressão é que a instituição está sempre atrasada devido ao infindável número de processos a julgar e por isso tenta se realizar da forma mais rápida possível.

O JECRIFAM parecia operar de maneira diferenciada, o número de casos de violência doméstica tinha uma média pouco superior a mil por ano. Por conta deste número havia tempo para um aprofundamento de cada caso, apesar da estrutura estar um pouco aquém da ideal para tal funcionamento. Porém, já em meados de 2004, dez meses após sua inauguração, houve uma mudança na distribuição de processos e o Juízo (magistrados) teve que se responsabilizar por todos os procedimentos judiciários cabíveis à Lei 9.099/95. Mais de 15.000 processos foram encaminhados de uma só vez e aquela estrutura que se mostrava um pouco aquém do ideal foi responsabilizada por algo impossível de realizar. E um número enorme de processos continuou chegando. A partir deste momento o julgamento dos casos de 
família foi afetado, apesar dos grandes esforços dos juízes em sustentar alguma qualidade mínima.

O primeiro efeito direto destes desencontros era um descontentamento pessoal dos cidadãos, que aparecia na repetida, e desconfortável, fala dos usuários do Fórum: "não era bem isso que eu esperava...”. Esta frustração se dava, também quando os cidadãos implicados no procedimento judiciário criavam a expectativa de que a Justiça realizasse aquilo que achavam, particularmente, justo, o que muitas vezes ia à contramão do funcionamento da instituição. O cidadão acabava por se alienar do exercício de cidadania que estava realizando por conta do desconforto causado por esses desencontros discursivos.

Alguns desses desencontros geravam, ainda, o efeito de perda do sentido da Justiça e/ou depreciação da Instituição Judiciária no imaginário popular, o que pode afetar diretamente as possibilidades de exercício da cidadania numa perspectiva presente (quando deste específico percurso) e futura.

Por fim, algo da função de referência da Justiça ao cidadão parecia ainda operar quando de uma recomendação do juiz: a palavra do magistrado pareceu ainda ter efeitos de autoridade sobre os cidadãos. 


\section{Da presença do psicólogo-psicanalista junto a atores institucionais}

A presença de um Setor ao qual podiam referir-se sobre questões da subjetividade acabou promovendo algumas mudanças no discurso dos atores institucionais mais diretamente próximos. Promotores, juízes e advogados dativos em diferentes momentos dirigiram falas ao psicólogo-psicanalista. Parece importante reportar algo destas falas a fim de melhor localizar as relações intra-institucionais e seu funcionamento. Além destas falas é importante ressaltar que também alguns documentos oficiais circularam entre o Setor de Psicologia e os outros setores do Juizado. As mudanças dos discursos dos parceiros institucionais que ocorreram ao longo do tempo podem servir como recurso para entendermos a legitimação do Setor de Psicologia dentro da estrutura do Juizado.

Considero relevante relatar apenas as demandas, aqui no sentido de pedidos apresentados via linguagem, dirigidas ao Setor de Psicologia. Os pedidos dirigidos ao Setor facilitam o entendimento quanto às expectativas e o lugar ocupado por este dentro da dinâmica do JECRIFAM. As demandas inicialmente formuladas foram: o cuidado das vítimas e acalmar as partes antes do julgamento.

Ao longo destes mais de três anos outras falas foram sendo dirigidas ao Setor de Psicologia do JECRIFAM. As demandas que se seguem são apresentadas na mesma ordem em que foram faladas: que os usuários resolvam quanto ao que querem antes de ir à audiência; outra referência para o entendimento das dinâmicas entre as partes; que a resposta da Justiça seja mais efetiva, no sentido de diminuição da re-incidência; que se trabalhe junto às famílias para que estas lhes dirijam demandas pertinentes às possibilidades de resposta judicial; recursos para os operadores do Direito não se sentirem tão cansados em audiências de família; além de outras que optei por não apresentar. 
Parece importante, ao escrever sobre os operadores do Direito, acrescentar algumas informações que pretendem possibilitar ao leitor das áreas Psicologia e Psicanálise entender melhor a prática destes outros profissionais.

Muitas vezes fica à responsabilidade destes profissionais a tarefa de tentar (re)estabelecer uma ligação entre Justiça e justiça, ou apenas possibilitar que de alguma forma uma se refira à outra. Lembro aqui que quando falamos Justiça nos referimos a uma instituição, gerida pelo Poder Judiciário, no qual se realizam os ritos jurídicos, sempre referidos à Constituição e Leis Ordinárias, Complementares etc, enquanto que falar em justiça é referir-se ao que é justo, ou seja, o que é certo ou cabível numa perspectiva moral e/ou ética. Temos que, por exemplo, a realização da Justiça pode ser injusta em determinado caso, enquanto que realizar algo aparentemente justo (justiça) pode, em outro caso, ser ilegal.

Parece importante retomar a consideração acerca das dificuldades de diálogo e tomada de posições quando estes profissionais juntam no mesmo campo as expectativas de particulares e contratos instituídos ou legítimos. Quando as questões e posicionamentos em jogo se articulam a partir das intrincadas dinâmicas familiares (que às vezes remetem a várias gerações) o contexto pode ficar muito complexo, gerando toda sorte de desencontro e dificuldade. Em alguns casos mais difíceis os operadores do direito pediam ajuda técnica ao psicólogo-psicanalista.

Sobre a noção de referência como recurso para o trabalho. Referência neste trabalho opera com duas funções principais, como significante e como valor ético. Comecemos pela segunda.

Uma leitura de campo à época da implementação do Setor de Psicologia permitiu o entendimento de que, para além do oferecimento de um cuidado psicológico-psicanalítico para os usuários do Juizado, havia a intenção de apoio à realização de Justiça a partir da criação de um dispositivo multiprofissional de trabalho. Com o tempo tal leitura do campo foi 
se consolidando, de forma a sustentar que também a presença de um profissional psi dentro do tribunal portasse como um de seus objetivos o funcionamento da instituição. Tal apoio parece pertinente, mas afinal no que a Psicanálise poderia contribuir para o funcionamento desta instituição?

Faz-se imprescindível então localizar o porquê e como trazer tais contribuições pode enriquecer um trabalho de encontro entre cidadão e Justiça. De saída seria possível sustentar que mais do que fundamentar uma compreensão da condição humana, tais contribuições poderiam orientar a escuta do técnico psi na direção do serviço oferecido, mesmo que tal serviço não se constituísse como um tratamento nos moldes tradicionais. E, mais ainda, para além do encontro técnico-usuário, a sustentação de algumas proposições freudianas pareceu agregar importantes valores a toda dinâmica deste encontro cidadão-Justiça indiretamente, por propiciar/provocar debates entre atores institucionais.

A instituição se atualiza a cada ato de seus partícipes, sejam eles os operadores do direito, usuários (cidadãos), equipe de segurança (Polícia Militar) e burocracia (pessoal do cartório) e também no ato do psicólogo-psicanalista... uma intervenção, dois efeitos: responsabilização civil e subjetiva. 


\section{Sobre as estatísticas atuais e as do Setor de Psicologia}

Neste trecho serão apresentadas algumas estatísticas sobre a temática da violência doméstica. Uma primeira leitura dessas estatísticas apresenta um quadro social brasileiro com grande incidência de violência doméstica, no qual a mulher aparece como a principal vítima. Mas, visando pertinência com a proposta desta dissertação, entendo que algumas questões devam ser discutidas antes da apresentação destes números, uma vez que para além da dimensão clínica do serviço faz-se necessário também considerar um recorte político.

A escolha por apresentar estatísticas merece reflexão, pois se consideramos que debate e pertinência do serviço em questão só ganham sentido se contextualizados politicamente, deveremos necessariamente nos resguardar por uma leitura política para fundamentar a apresentação de quaisquer dados estatísticos. Afinal, como sustentar a pertinência da apresentação de estatísticas se a principal referencia é a Psicanálise?

Este resguardo se estende à percepção do contexto político atual, no qual muitas vezes dados estatísticos acabam ocupando a função de referenciais únicos, ou principais, para algumas leituras da realidade. É mais que comum vermos a implementação e/ou mudanças em políticas públicas que têm como fundamento resultados estatísticos de pesquisas, que propõem determinadas "leituras da realidade", muitas vezes em detrimento do discurso portado pelos atores sociais e institucionais diretamente implicados (às vezes até "atingidos") por tais implementações e mudanças. Em diversos contextos não é raro ouvir destes atores institucionais e sociais o descontentamento pela falta de consulta anterior a tais modificações, ou o quanto tais mudanças não fazem sentido para os mais diretamente envolvidos. Por este motivo, entre outros, dados estatísticos são comumente vistos como instrumentos de silenciamento facilmente manipuláveis, posto que aparentemente apresentam uma realidade que parece poder se constituir à revelia dos discursos dos diretamente implicados. 
Sustentamos que no contexto de políticas públicas, no entanto, as estatísticas podem ser de grande valia se, e somente se, se prestarem à função de referência não única e nunca como instrumento de silenciamento. É importante afirmar, assim, que por mais que possamos estar referidos também aos resultados de pesquisas estatísticas, esta referência de forma nenhuma pode se prestar à função de deixarmos de ouvir os discursos dos implicados.

Parece que a tentativa de dialogar com os discursos atualmente em voga é responsabilidade inerente à discussão, dado que há a pretensão de efeito nos espaços públicos. Para poder sustentar nossa atenção ao sujeito do inconsciente se faz necessário circular por estes discursos instituídos, e mesmo que se considere que um discurso referenciado pela estatística possa se prestar à função de apagar este sujeito, sustento que não se deva recuar da tentativa de diálogo.

O material abaixo representa um recorte breve dos principais (quanto à legitimidade institucional e relevância política das fontes) discursos fundamentados em dados estatísticos disponíveis no momento sobre a temática em questão.

No sítio virtual do Instituto Brasileiro de Geografia e Estatística, IBGE,

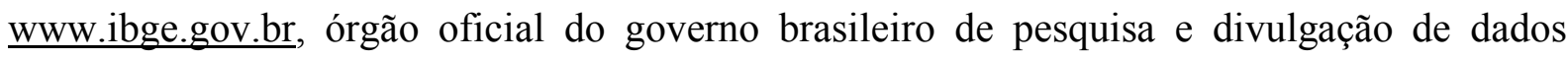
estatísticos sociais, encontramos algumas poucas referências à temática, que se seguem:

Você sabia que 11\% das brasileiras com 15 anos ou mais já foram vítimas de espancamento? Sabia também que o marido ou companheiro é responsável por $56 \%$ desses casos de violência?

(in: http://www.ibge.gov.br/ibgeteen/datas/mulher/especial.html)

de $20 \%$ a $50 \%$ das mulheres no mundo já foram vitimas de assalto; uma em cada dez já foi estuprada; 30 milhões já foram mutiladas em todo o planeta.

(in: http://www.ibge.gov.br/ibgeteen/datas/mulher/contraviolencia.html)

No sítio virtual do Instituto Patrícia Galvão, www.patriciagalvao.org.br, organização responsável pela divulgação de estatísticas e informações sobre violência contra mulheres com diversas parcerias, encontramos outros discursos, na mesma linha daqueles portados pelo IBGE, em recente pesquisa: 
$33 \%$ apontam a violencia contra as mulheres dentro e fora de casa como o problema que mais preocupa a brasileira na atualidade.

Do total de entrevistados, $51 \%$ declaram conhecer ao menos uma mulher que é ou foi agredida por seu companheiro. Entre as mulheres este conhecimento é maior (54\%). Os segmentos que expressam taxas maiores de familiaridade com esse drama são de pessoas de 25 a 29 anos (59\%), com escolaridade superior (59\%) e morador da periferia (57\%).

No mesmo sítio, encontramos ainda alguns recortes de pesquisa referidos à

Justiça, ou à aplicação da mesma, dentro deste contexto:

Em cada quatro entrevistados, três consideram que as penas aplicadas nos casos de violência contra a mulher são irrelevantes e que a justiça trata este drama vivido pelas mulheres como um assunto pouco importante.

$54 \%$ dos entrevistados acham que os serviços de atendimento a casos de violência contra as mulheres não funcionam.

Nove em cada 10 mulheres lembram de ter assistido ou ouvido campanhas contra a violência à mulher na TV ou rádio.

Perguntados sobre o que acham que acontece quando a mulher denuncia, $33 \%$ dos entrevistados afirmaram que 'Quando o marido fica sabendo, ele reage e ela apanha mais'; 27\% responderam que não acontece nada com o agressor; $21 \%$ crêem que o agressor vai preso; enquanto $12 \%$ supõem que o agressor recebe uma multa ou é obrigado a doar uma cesta básica.

(in: http://www.patriciagalvao.org.br/apc-aa-patriciagalvao/home/noticias.shtml?x=527)

O jornal de notícias, sobre Judiciário, Direito e Leis, Última Instância, em seu sítio

virtual www.ultimainstancia.uol.com.br, também apresenta discursos com fundamentação estatística (dados do Setor Técnico de Apoio às Delegacias de Defesa da Mulher do Estado de São Paulo) sobre a temática em questão:

em todo o ano de 2006, 187.282 ocorrências contra a mulher foram registradas no Estado de São Paulo. O número equivale a pouco mais de 512 ocorrências por dia, ou mais de 21 por hora.

No ano passado, as delegacias de defesa da mulher receberam 92.682 denúncias de lesões corporais dolosas, 4.402 de maus-tratos e 90.198 de ameaças, totalizando as 187.282 mil ocorrências

(in: http://ultimainstancia.uol.com.br/curriculos/?idAutor=507)

Apesar destes discursos, existem poucas fontes de dados estatísticos sobre a temática da violência doméstica disponíveis nos sítios oficiais e as informações que são encontradas geralmente estão esparsas, referem-se a um único ano, foram estabelecidas com bases em 
diferentes referências, ou seja, não estão padronizadas, apresentam incongruências etc. Os motivos desta não padronização, e/ou continuidade, apresentados pelas diferentes instituições que se propõem a divulgar tais dados são vários: alterações constantes nas políticas públicas, Leis e referências no trato da matéria; falta de pessoal e planejamento necessários; dificuldade de acesso à população e informação pelo silenciamento das famílias que não procuram as instituições responsáveis, seja pela dificuldade inerente à abertura de um conflito que geralmente permanece no não-dito, seja por falta de informação quanto a quem recorrer; pelo silenciamento dos técnicos que não se sentem preparados e/ou à vontade no trato com a temática; e o tipo de uso que se dá a essas estatísticas etc.

Além dessas dificuldades em se sustentar uma política de pesquisa quantitativa, há outro silenciamento operando sobre o campo: algumas Organizações Não Governamentais, ONGs, especializadas na matéria em questão, afirmam que apenas $25 \%$ dos casos de violência doméstica chegam, atualmente, ao conhecimento dos órgãos oficiais (dado corroborado pela ONU).

Diante desta perspectiva parece difícil estabelecer diálogo que utilize tais fontes de informação estatística como principal referência, mas, apesar disso posto, entendo que podemos afirmar, com base nestes dados não tão esclarecedores e, mais que isso, na insistência com a qual estes discursos emergem em nosso cotidiano, que a violência doméstica é fenômeno corrente em nossa sociedade e por isso é pauta de debates públicos atuais. Apesar de todas essas dificuldades, fala-se, e bastante, sobre isso. Mas como se fala, em que circunstâncias e quais os ensejos e efeitos destas falas?

Para além de um posicionamento frente aos atuais discursos referidos às estatísticas, outra referência comum a estes discursos aparece constantemente quando nos questionamos quanto ao que portam tais discursos quanto à forma, geralmente estanque, de ocupação dos lugares sociais pela mulher e seus cônjuges no que diz respeito à violência. Como vimos nesta 
sessão e na anterior, o posicionamento da mulher como principal vítima da violência doméstica, nestes citados discursos, chama a atenção. Mais do que questionar a veracidade de tais informes, uma vez que parece não haver dúvidas quanto ao fato de que muitas mulheres sofram sim violência dentro de seus lares, entendo que caberia discutir que posição é esta que tais discursos parecem portar. Não raro, a identificação social da mulher ao papel de vítima, é corroborado/reforçado pelos discursos acima citados, pode direcionar a participação dessas mesmas mulheres na contramão de um exercício da cidadania ativo/crítico, promovendo a ocupação de um lugar silenciado e passivo. Por este motivo as mulheres usuárias dos serviços foram denominadas, nos relatórios oficiais como "demandantes" ou "queixantes", a fim de tentar identificá-las para os operadores do Direito a partir de uma leitura qualitativa sobre o discurso que portavam e que deu causa à ação judiciária.

Uma posição política a partir da Psicanálise acerca das estatísticas na atualidade, para além de denunciar este efeito de silenciamento, pode ser o movimento de chamar atenção aos efeitos que a apresentação das estatísticas parece causar nos cidadãos, e que talvez até se estenda ao tecido discursivo social. Atualmente, vemos que a apresentação de dados estatísticos se presta à função de justificativa de tomadas de posição política dos governantes, o que parece bastante pertinente. Mas esta apresentação re-iterada de estatísticas tem mobilizado os cidadãos? Se sim, como se dá tal mobilização?

Parece, antes, que tem um efeito de gozo, no sentido de um êxtase soporífero, de sideração, torpor, em sua incidência repetitiva nos sujeitos-cidadãos. Sobre o gozo é preciso afirmar que, para além de suas características qualitativas que se apresentam nas singularidades de cada um, há que percebe-lo nas repetições e ciclos nos quais cada um se vê envolvido. Temos que essas estatísticas parecem mais com uma mostração continuada que não causa desejo algum, posto que não movimenta, não instaura/reconhece a falta, não faz questão, mas antes mantém passivos aqueles à qual se refere. A observação fica facilitada 
quando pensamos nesta característica do gozo de tender à repetição, à constituição de ciclos repetitivos, cada vez pior e com intervalos de tempo mais breves.

Ao longo da existência do Setor de Psicologia do JECRIFAM foram atendidas no total 618 famílias, além de 74 usuários de entorpecentes e 8 vítimas de violência sexual. 
PARTE III

CHEGANDO A UM FINAL 


\section{Cenário interinstitucional e político ao longo da existência do}

\section{Setor de Psicologia do JECRIFAM e a situação atual}

Este capítulo relata algumas passagens mais significativas do cenário interinstitucional e político no qual se estruturava o Setor de Psicologia do JECRIFAM ao longo de seu período de existência. Apresenta também algumas considerações sobre a situação atual. Para tanto é apresentado primeiramente o percurso das relações com o CRAVI e com a Secretaria da Justiça e da Defesa da Cidadania, seguido do percurso de desdobramentos da Justiça Criminal em torno da temática da violência doméstica e por fim são tecidas algumas considerações acerca da situação atual, na qual se engendrou outro serviço que usa como referência esse que é mote desta dissertação.

A condição de falta de comunicação com o CRAVI permaneceu até o início de 2005, quando começou, com alguma timidez, uma aproximação entre este psicólogo-psicanalista e o referido programa. Uma posição política explicitada pela coordenação do CRAVI à época parecia explicar, apesar de não justificar, as dificuldades de comunicação: entendiam que uma aproximação à Secretaria da Justiça poderia por em risco o CRAVI e por isso buscavam ao máximo sustentar suas realizações à revelia do gabinete.

$\mathrm{O}$ argumento desta coordenação era de que o gabinete estava apenas interessado em negociações políticas de governo e pouco se interessava pela qualidade do serviço público oferecido. Havia um temor de que se o CRAVI "aparecesse muito" na Secretaria da Justiça e da Defesa da Cidadania, correria o "risco" de ser usado como plataforma de propaganda política ou como espaço para favorecimentos (colocação de funcionários não habilitados, espaço do uso para outras funções, ingerências administrativas etc). 
Esta postura, próxima a algo como uma tentativa de isolamento, parecia influenciar também a relação com o projeto-piloto. A insistência do psicólogo-psicanalista, no entanto, parecia começar a incomodar e a coordenação do CRAVI decidiu mudar de postura: iriam incentivar o crescimento do Setor de Psicologia de forma que este pudesse ter condições (subsídios suficientes) para se desvincular completamente do CRAVI. A idéia era constituir um campo de pertinência para que projeto-piloto e programa tivessem verbas independentes.

A partir de maio de 2005, depois de reiterados pedidos e reclamações a coordenação do CRAVI, via ONG parceira do CRAVI, o Instituto Therapon Adolescência, decidiu subsidiar uma supervisão para o Setor de Psicologia. Apesar do subsídio vir via ONG tratavase de verba do Governo Federal propriamente destinada a ampliação de alguns horizontes de trabalho no CRAVI.

O tipo de supervisão oferecido recebia o nome de supervisão institucional, modelo congruente com as diretrizes desta $\mathrm{ONG}$, que se afirmava sob dupla referência: Esquizoanálise e Psicanálise. Tal dispositivo criou um espaço de reflexão novo no Setor de Psicologia, no qual se focava principalmente as relações entre estagiários e psicólogopsicanalista e o encaminhamento de alguns casos mais difíceis.

Ao final do ano de 2005 houve a primeira possibilidade de diálogo direto com a Secretaria da Justiça e da Defesa da Cidadania, que a partir de então começou aos poucos a se responsabilizar pelo projeto para, apenas em agosto de 2006 na gestão da Dra. Eunice Aparecida de Jesus Prudente, aproximar a direção política da Secretaria de Estado (gabinete) ao serviço, chegando até a aumentar os investimentos no Setor de Psicologia do JECRIFAM ao "descobrir" a situação à época: o serviço tinha êxito e era muito bem considerado pelos atores institucionais do Fórum, porém apresentava-se em condição miserável de recursos. 
Desde meados de 2004 o JECRIFAM somou a suas responsabilidades julgar também todos os casos da Lei 9.099/95, passando a operar conjuntamente como JECRIFAM e JECRIM (Juizado Especial Criminal). A redistribuição dos processos (pg. 58) acarretou em uma obliteração do sentido que se tentava empreender. Os esforços para conter este "transbordamento" foram inúmeros e algum cuidado diferenciado aos casos de violência doméstica pôde ser mantido.

O JECRIFAM era assunto e conseguia alguns bons resultados, o que não parece ser muito comum à instituição. Até que em um espaço de seis meses, a partir de maio de 2005, a coordenação do Juizado foi trocada três vezes em seguida. O que já era muito difícil de fazer operar com alguma qualidade estancou. Seguiu-se uma greve do cartório e os exíguos prazos de operação do Juizado começaram a estourar. Os novos juízes coordenadores que assumiram bem tentavam sustentar alguma qualidade diferenciada no atendimento às famílias, porém ao final de 2005 parecia que apenas o Setor de Psicologia estabelecia uma diferença entre as operações de JECRIM e JECRIFAM.

As reclamações dos usuários começaram a despontar como uma constante, casos só chegavam ao Setor de Psicologia mais de um ano após a queixa na delegacia. Como esperar a promoção da cidadania se a Justiça estava, neste contexto específico, inoperante, impotente? As dificuldades foram inúmeras, eclodiram problemas de relacionamento no cartório: ninguém mais parecia confiar na qualidade do serviço oferecido.

O ano de 2006 foi marcado pela tentativa de recuperar a qualidade dos atendimentos do Juizado às famílias até que em setembro de 2006 entrou em vigor a Lei 11.340, também conhecida como Lei Maria da Penha. A Lei 11.340/06 alterou profundamente o funcionamento da Justiça Criminal nos casos de violência doméstica nos quais a mulher figura como vítima. 
A vigência desta Lei levou a extinção do JECRIFAM em janeiro de 2008, após o término do julgamento dos casos ainda pendentes (com queixas anteriores a setembro de 2006).

Mas antes disso, no início do ano de 2007, as eleições estaduais para governador trouxeram uma mudança no cargo de Secretário da Justiça e da Defesa da Cidadania, assumindo o Dr. Luiz Antônio Guimarães Marrey, que teve como uma de suas metas iniciais uma ampliação dos programas que oferecem referência e promovem o exercício de cidadania, entre eles o CRAVI. Visando tal ampliação, a coordenação do CRAVI foi substituída. Além disso, partiu-se da idéia de que novas unidades seriam fundadas.

A partir de fevereiro de 2007 o modelo de intervenção do Setor de Psicologia do JECRIFAM se somou a outros modelos de serviços para a fundação de um novo Centro de Referência e Apoio à Vítima no Fórum Criminal Central, o CRAVI - Fórum Criminal. O CRAVI se expandiu, assim, para além de sua sede. Esta nova sede do CRAVI, no Fórum Criminal, conta com equipe multidisciplinar que oferece atendimento aos usuários deste Fórum, vítimas diretas ou indiretas de violações graves dos Direitos Humanos, especificamente: crimes dolosos contra a vida, violência doméstica e sexual. Desta forma houve também uma ampliação do programa CRAVI, que a partir de fevereiro de 2007 somou o modelo de serviços do já estabelecidos no CRAVI com o modelo se serviço do Setor de Psicologia do JECRIFAM.

O que se mostra deste novo contexto de política pública no entanto não aponta para uma continuidade do serviço aqui apresentado. Tal serviço operava diretamente ligado ao andamento dos processos no Juizado, à realização da Justiça, enquanto que as operações possíveis no CRAVI caminham paralelamente ao andamento da Justiça Criminal. Há uma somatória de esforços mas não uma ligação direta. O serviço realizado no Setor de Psicologia 
do JECRIFAM serve como uma das fontes da atuação destes novos profissionais no atendimento direto a população usuária do Fórum Criminal.

Com essas mudanças, o modelo de intervenção apresentado nesta dissertação contribuiu diretamente para a realização de uma política pública. O fato de contar agora com equipe multidisciplinar trouxe mudanças ao modelo apresentado nesta dissertação que, no entanto não serão aqui apresentadas por se encontrarem em fase de consolidação.

O final do ano de 2007 foi também marcado pelo término da parceria de cinco anos com a ONG Instituto Therapon Adolescência. O gabinete da SJDC, via secretário adjunto, decidiu que a coordenação do programa CRAVI deveria ser portada exclusivamente pelo Governo, não renovando o contrato de coordenação em parceria público-privada. Tal decisão promoveu uma aproximação com o gabinete, o que parece importante por legitimar as ações institucionais. Por outro lado, $30 \%$ dos casos de homicídio atendidos pelo CRAVI são referentes à ação de agentes do estado (em serviço e fora de serviço). Os dados fruto de tal atendimento serem manejados apenas por funcionários do Governo parece ser operação um tanto complicada, que poderia remeter a uma discussão interminável... 


\section{Considerações finais}

Neste capítulo de considerações finais pretendo retomar um pouco o percurso de todo o texto e promover uma amarração possível sobre os pontos fundamentais. Ao longo de toda a dissertação diversas questões e posicionamentos foram suscitados e parece importante neste momento de conclusão retomar o produto dessas reflexões a fim de promover essa amarração possível. A intenção não é responder de forma a encerrar os assuntos provocados por tais questões e posicionamentos, mas antes dar indicações de caminhos possíveis de trabalho a partir destes pontos.

O funcionamento do JECRIFAM propunha práticas jurídicas e multidisciplinares que ampliassem as possibilidades de operação da Justiça Criminal em casos de violência doméstica, ao tratar a matéria penal por um viés que não se restringia a uma pura apuração de fatos, abrindo também a possibilidade de fala das partes acerca das motivações da busca na Justiça. A ação penal condicionada à representação abriu campo de reflexão e responsabilização para os cidadãos usuários dentro do Fórum Criminal de São Paulo.

A presença do psicólogo-psicanalista e a disposição dos operadores do direito diretamente envolvidos com o procedimento judiciário constituíram tal campo, de acordo com as possibilidades de cada sujeito-cidadão e/ou grupo familiar.

Tais reflexões e responsabilizações ultrapassavam, em muitos casos, uma pura responsabilização penal, promovendo também uma responsabilização subjetiva que abarcava o caráter historial e singular destes sujeitos-cidadãos.

Desta forma tentou-se ao máximo possível (respeitando os limites legais, institucionais e pessoais em jogo) que a passagem pela instituição judiciária fosse vivida como uma experiência consistente de exercício de cidadania. 
Essas experiências de exercício de cidadania foram dificultadas por diversos fatores, apresentados ao longo do texto, sobre os quais pode-se apontar duas constantes: estes fatores parecem profundamente enraizados em nossa Cultura e parece haver poucos com disposição de questionar e propor mudanças. O que não impede que sejam pauta constante de queixas e reclamações nos mais diversos âmbitos.

Mas, o que pode o corpo civil realizar no sentido de ultrapassar esta diz-posição queixosa e se responsabilizar efetivamente por uma mudança de posição? A própria noção de corpo civil, ou cidadania, parece de tal forma desarticulada na atualidade que fica difícil vislumbrar qualquer horizonte de mudança.

Vimos como as aparentes dificuldades de inserção social para casos de sujeitos que portam um discurso delirante podem ser superadas, promovendo um exercício da cidadania possível para tais sujeitos. Porém tal realização parece depender de uma soma de fatores dificilmente encontrada e outros contextos. Mas como promover/provocar a estruturação de tais fatores em outros âmbitos? Esta também parece ser importante questão para a cidadania na atualidade.

Vimos, também, que a presença do analista na instituição parecia lembrar aos implicados (agentes estatais e cidadãos) que ainda existe política, para além da partidária. Mas há vontade política destes partícipes implicados em reconhecer que ainda estamos inseridos em um contexto político ${ }^{19}$ ? Questão difícil na atualidade...

Algumas reflexões podem ser realizadas acerca desta questão, aqui me contento em apenas apontar três direções, sob a forma de questões: A que, ou quem, se presta a consideração do cidadão à revelia de sua subjetividade? Pode haver cidadania de um fora da cidadania de todos? Haveria como publicizar os meios de atravessamento dessas negações da tendência do sujeito-cidadão à política?

\footnotetext{
${ }^{19}$ Sobre este ponto parece passagem obrigatória a leitura da série de acordos MEC-USAID.
} 
Pareceria quase utópico pensar que algum dia alguém se interessasse por questões desta ordem, mas essas questões são fruto de um percurso prático que pôde contar com alguma reflexão, parte da qual narrada nesta dissertação. Sobre a primeira questão valeria atentar para as possíveis dificuldades de consolidação de uma Justiça que operasse radicalmente para as questões subjetivas, o que de forma alguma esvazia de sentido esta questão, apenas apontando para alguns de seus limites.

A proposta lacaniana para responder a questões como estas é o ato de transmissão da Psicanálise. Esta é uma posição política de alguns psicanalistas.

Nestes tempos nos quais impera uma "fantasia coletiva" de formação acadêmica puramente teórica e virtualização das relações humanas, parece que a contribuição da experiência encontra dificuldades de encontrar espaço legítimo. Parece, ainda, que algo de uma tirania ideológica se encontra em ação. O lugar cabível aos psicanalistas na contemporaneidade, posto que insistem em apontar verdades experienciais neste contexto de paranóia generalizada, postando-se quase como que estrangeiros a tal ingenuidade, pode ser muito mal compreendido se a referência interpretativa estiver unicamente fundamentada nessa ideologia.

Por fim, o percurso desta dissertação em torno da questão que escuta cabe oferecer neste contexto? pode se prestar futuramente a facilitar o tempo de compreender de um psicólogo-psicanalista que se depare com uma abertura de campo fortuita como esta. 


\section{BIBLIOGRAFIA}

BAKHTIN, M. - Marxismo e filosofia da linguagem, Editora Hucitec, São Paulo, 1995.

BRANDÃO, C. R. - Em campo aberto, Cortez Editora, São Paulo, 1995.

CAFFÉ, M. - Psicanálise e direito, Quartier Latin, São Paulo, 2003.

CASTRO, L. R. F. - Disputa de guarda: no interesse dos pais ou dos filhos?, Casa do Psicólogo, São Paulo, 2003.

CONTÉ, C. - O Real e O Sexual, de Freud a Lacan - Jorge Zahar Editor, Rio de Janeiro, 1995.

COUTINHO, J. N. M. - Direito e Psicanálise, Lúmen Júris, Rio de Janeiro, 2006.

DELMANTO, C. - Código Penal Comentado, Edição Renovar, São Paulo, 2002.

DOR, J. - Introdução à leitura de Lacan, o inconsciente estruturado como linguagem, Artmed Editora, Porto Alegre, 2003.

DUNKER, C. I. L. - O cálculo neurótico do gozo, Escuta, São Paulo, 2002.

ENRIQUEZ, M. - Nas encruzilhadas do ódio, Escuta, São Paulo, 2000.

Estatuto da Criança e do Adolescente - Lei $n^{\circ}$ 8.069/90, Lei $n^{\circ}$ 08.074/92, Lei $n^{o}$ 8.242, Decreto 30.059/94, Decreto $n^{\circ} 39.104 / 94$.

Escola Superior do Ministério Público de São Paulo - Juizado Especial Criminal, Imprensa Oficial S. P., São Paulo, 2002.

FREUD, S. - Edição Standard Brasileira das Obras Psicológicas Completas de Sigmund Freud - edição standard, Editora Imago, Rio de Janeiro, 1996.

Edição Eletrônica Brasileira das Obras Completas de Sigmund Freud, Imago, 1999.

HOLLANDA, S. B. - Raízes do Brasil, Companhia das Letras, São Paulo, 1996.

KAËS, R. - Transmissão da vida psíquica entre gerações, Casa do Psicólogo, São Paulo, 2001.

KAUFMANN, P. - Dicionário Enciclopédico de Psicanálise, Jorge Zahar Editor, Rio de Janeiro, 1993.

LACAN, J. - Escritos, Jorge Zahar Editor, Rio de Janeiro, 1998.

O Seminário, Livro II - O eu na teoria de Freud e na técnica da psicanálise, Jorge Zahar Editor, Rio de Janeiro, 1985.

O Seminário, Livro III - As psicoses, Jorge Zahar Editor, Rio de Janeiro, 1985. O Seminário, Livro V-As formações do inconsciente; Jorge Zahar Editor, Rio 
de Janeiro, 1985.

O Seminário, Livro VII-A ética da psicanálise, Jorge Zahar Editor, Rio de Janeiro, 1988.

O Seminário, Livro VIII - A transferência; Jorge Zahar Editor, Rio de Janeiro, 1992.

O Seminário, O Seminário, Livro XI - Os quatro conceitos fundamentais da psicanálise, Jorge Zahar Editor, Rio de Janeiro, 1985.

O Seminário, O Seminário, Livro $X-A$ angústia; Jorge Zahar Editor, Rio de Janeiro, 2005.

O Seminário, Livro XVII - O avesso da psicanálise; Jorge Zahar Editor, Rio de Janeiro, 1992.

O Seminário, Livro $X X-$ Mais, ainda...; Jorge Zahar Editor, Rio

de Janeiro, 1985.

Os complexos familiares, Jorge Zahar Editor, Rio de Janeiro, 1985.

Outros Escritos, Jorge Zahar Editor, Rio de Janeiro, 2003.

R. S. I., Transcrição dos seminários de 1974-75.

Lei 9.099 de 1995 - sítio virtual da Presidência da República.

Lei 11.340 de 2006 - sítio virtual da Presidência da República.

MORETTO, M. L. T. - O Que Pode um Analista no Hospital - Casa do Psicólogo, São Paulo, 2002.

MUSZKAT, M. E. - Mediação de Conflitos, Summus Editorial, São Paulo, 2003.

NASIO, J.-D., - A alucinação e outros estudos lacanianos, Jorge Zahar Editor, Rio de Janeiro, 1997.

Psicossomática. As formações do objeto a, Jorge Zahar Editor, Rio de Janeiro, 1993.

O livro da dor e do amor, Jorge Zahar Editor, Rio de Janeiro, 1996.

OCARIZ, M. C. - O Sintoma e a Clínica Psicanalítica, O curável e o que não tem cura - Via Lettera, São Paulo.

QUINET, A. - Psicose e laço social, Jorge Zahar Editor, Rio de Janeiro, 2006. As 4+1 condições da análise, Jorge Zahar Editor, Rio de Janeiro, 1991.

RABELAIS, F. - Gargântua e Pantagruel, Vila Rica, Belo Horizonte,1991.

ROUDINESCO, E. - Jacques Lacan, Companhia das Letras, São Paulo, 1993.

Família em desordem, Jorge Zahar Editor, Rio de Janeiro, 2003.

O Paciente, o Terapeuta e o Estado, Jorge Zahar Editor, Rio de Janeiro, 2005. 
SHINE, S. - A espada de Salomão, a Psicologia e a Disputa de Guarda de Filhos, Casa do Psicólogo, São Paulo, 2003.

SILVA, F. L. - Felicidade, Editora Claridade, São Paulo, 2007.

ZIZEK, S. - Eles não Sabem o que fazem, o sublime objeto da ideologia, Jorge Zahar Editor, Rio de Janeiro, 1992. 